\title{
The Viséan sedimentary succession at the Gara el Itima (Anti-Atlas, Morocco) and its ammonoid faunas
}

\author{
Christian Klug*, ${ }^{*}$, Sascha Döring ${ }^{* *, 2}$, Dieter Korn ${ }^{* * *, 3}$ \& Volker Ebbighausen****, 4 \\ ${ }^{1}$ Paläontologisches Institut und Museum der Universität Zürich, Karl-Schmidt-Strasse 4, CH-8006 Zürich, Switzerland. \\ ${ }^{2}$ Institut für Geowissenschaften, Sigwartstraße 10, D-72076 Tübingen, Germany \\ (current address: Wintershall AG, P.O. Box 102040, D-34112 Kassel, Germany) \\ ${ }^{3}$ Museum für Naturkunde der Humboldt-Universität zu Berlin, Invalidenstraße 43, D-10115 Berlin, Germany \\ ${ }^{4}$ Engstenberger Höhe 12, D-51519 Odenthal, Germany
}

Received 16 April 2005, accepted 7 July 2005

Published online 01. 02. 2006

With 50 figures

Key words: sedimentology, transgressive-regressive cycles, Ammonoidea, Viséan, Carboniferous, Morocco, biodiversity.

\begin{abstract}
A late Viséan section of clastic and carbonatic rocks is described from the eastern part of the Anti-Atlas (Morocco). The sedimentary succession is a mixed carbonate-siliciclastic system influenced by sea-level fluctuations. The sedimentology of the section is interpreted with respect to transgressive-regressive cycles and systems tracts. Highstand sediments yielded ammonoid assemblages from six horizons; a total of 1,040 specimens separated into 20 species are described in the palaeontological section. The genus Itimaites is new, together with the 16 new species Itimaites parabolicus n. sp., Calygirtyoceras zrigatense n. sp., Sudeticeras fornicum n. sp., Sudeticeras pusillobatum n. sp., Sudeticeras occultornatum n. sp., Goniatites rodioni n. sp., Goniatites gerberi n. sp., Goniatites evelinae n. sp., Hypergoniatites fusiger n. sp., Neogoniatites worki n. sp., Dombarites bellornatus n. sp., Platygoniatites rhanemensis n. sp., Ferganoceras torridum n. sp., Prolecanites meandricus n. sp., Prolecanites mapesi $\mathrm{n} . \mathrm{sp} .$, Epicanites hamianensis n. sp., and Megapronorites itimensis n. sp.
\end{abstract}

Schlüsselwörter: Sedimentologie, Transgressions-Regressions Zyklen, Ammonoidea, Visé, Karbon, Marokko, Biodiversität.

\section{Zusammenfassung}

Ein aus Klastika und Karbonaten aufgebautes Obervisé-Profil wird vom östlichen Bereich des Anti-Atlas (Marokko) beschrieben. Bei der Sedimentabfolge handelt es sich um ein gemischtes Ablagerungssystem aus Karbonaten und Siliziklastika, das durch Meeresspiegelschwankungen gesteuert wurde. Die Sedimentologie des Profiles wurde hinsichtlich Transgressions-Regressions Zyklen und System Trakten interpretiert. Hochstand-Sedimente lieferten Ammonoideen-Vergesellschaftungen aus sechs Horizonten; insgesamt wurden 1040 Exemplare gefunden, die 20 Arten zugeordnet wurden und im paläontologischen Teil beschrieben sind. Die Gattung Itimaites sowie die 16 Arten Itimaites parabolicus n. sp., Calygirtyoceras zrigatense n. sp., Sudeticeras fornicum n. sp., Sudeticeras pusillobatum n. sp., Sudeticeras occultornatum n. sp., Goniatites rodioni n. sp., Goniatites gerberi n. sp., Goniatites evelinae n. sp., Hypergoniatites fusiger n. sp., Neogoniatites worki n. sp., Dombarites bellornatus n. sp., Platygoniatites rhanemensis n. sp., Ferganoceras torridum n. sp., Prolecanites meandricus n. sp., Prolecanites mapesi n. sp., Epicanites hamianensis n. sp. und Megapronorites itimensis n. sp. sind neu.

\footnotetext{
* E-mail: chklug@pim.unizh.ch

**E-mail: sascha.doering@wintershall.com

*** Corresponding author: e-mail: dieter.korn@museum.hu-berlin.de

**** E-mail: volker@vxr.de
} 


\section{Introduction}

It is probably the rather remote geographic position that prevented a previous discovery of the fossiliferous occurrences in the vicinity of the Gara el Itima, located about 40 kilometres eastnortheast of the village of Taouz (eastern Anti-
Atlas, Morocco). When geological exploration of the region of Taouz began in the 1930s, Clariond, according to an unpublished manuscript from 1937, found Carboniferous ammonoids at three places, i.e., at Bordj d'Erfoud immediately east of Erfoud, in the desert $12 \mathrm{~km}$ south of the Dar Kaoua Oasis, and near Bou Tarit southeast of
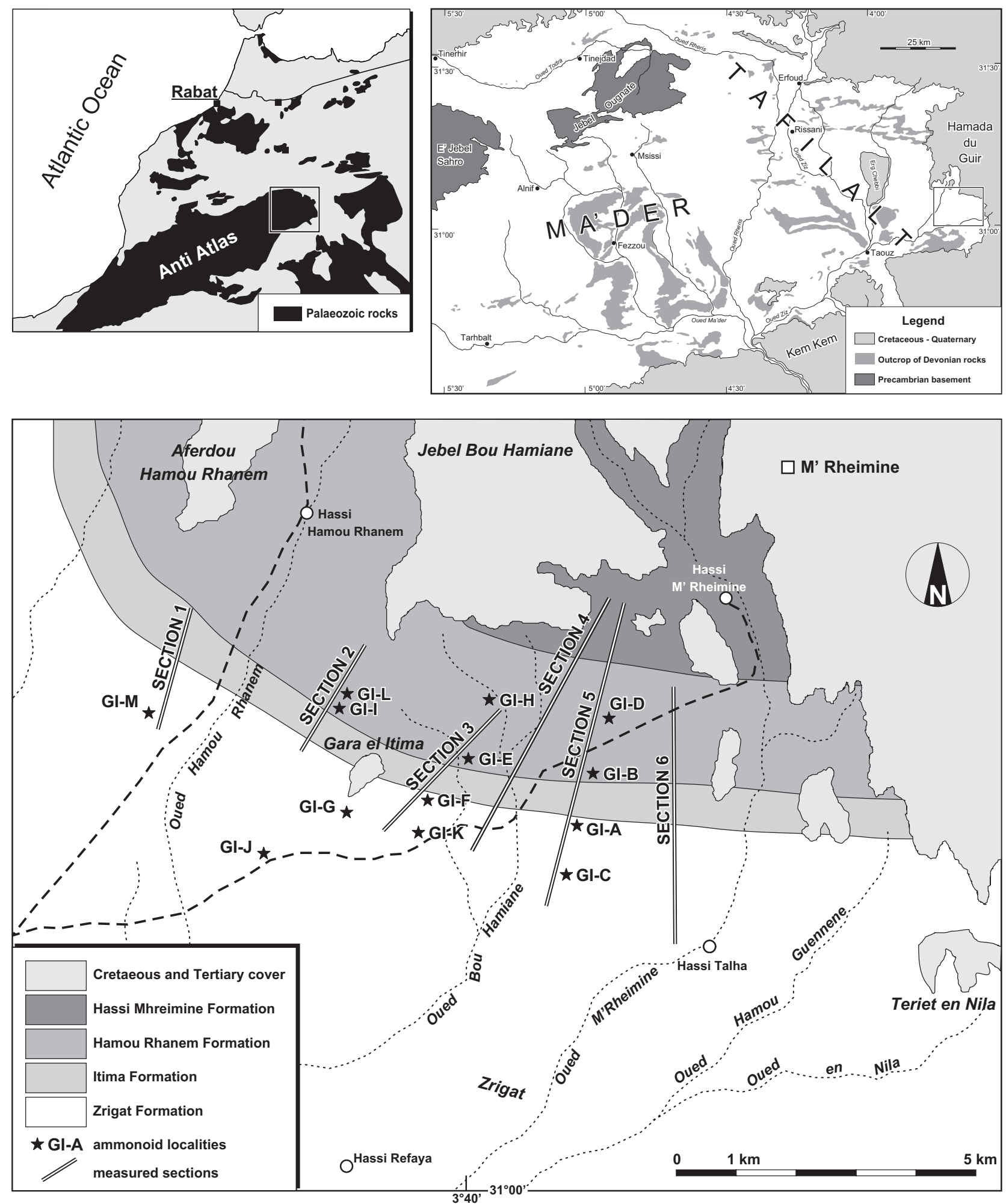

Fig. 1. Locality map showing the positions of the measured sections and fossil localities in the vicinity of the Gara el Itima in the Anti-Atlas (Morocco). 
Taouz. This material was investigated by Delépine (1941) who, in an extensive monograph, attributed these assemblages to various stratigraphic positions. However, some of his age determinations were incorrect including the putative presence of Arnsbergian (late Serpukhovian) goniatites from near the Dar Kaoua Oasis.

In an extensive field campaign of the working group of Jobst Wendt (Tübingen), some material from the old localities and also additional material was collected by C. K. and D. K. (then Tübingen). This material, mainly discovered in 1998, formed the basis for the report by Korn, Klug \& Mapes (1999). In this investigation, material from one single horizon from the Gara el Itima was illustrated for the first time.

During a field trip in March 2000, S. D., C. K., and D. K. assembled new material from some localities near the Gara el Itima. Additional material was collected during two field campaigns by V.E. in the springs of 2003 and 2004, together with D. Weyer (Berlin) and the working group of R. T. Becker (Münster). Promising results from the new material led to a more extensive field trip (V. E., D. K., and Rodion Ebbighausen, Köln) in November 2004. During this field trip,
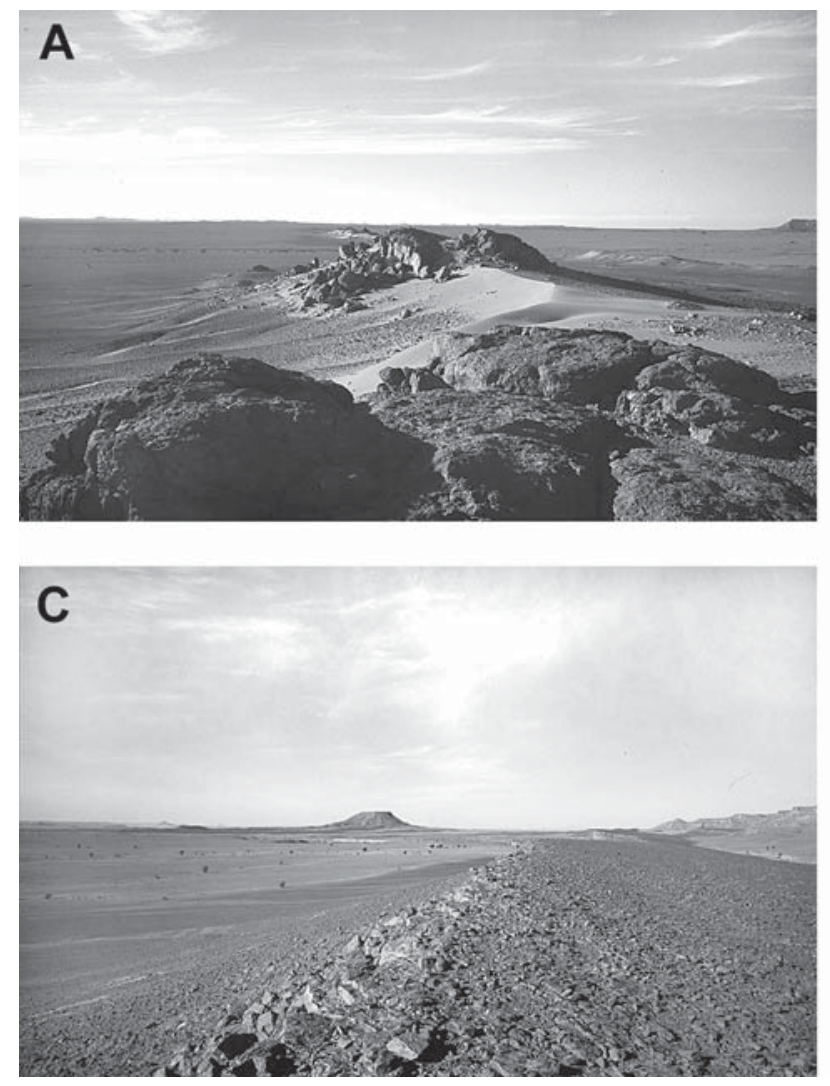

Fig. 2. Outcrop photographs showing some of the investigated rock formations. A - Zrigat Formation, lower part with "mudmound" facies; B - Zrigat Formation, higher part with crinoid grainstone facies; C - Base of the Hassi Mhreimine Formation with the Gara El Itima (Cretaceous sediments) in the background; D - Well-bedded limestones of the Hassi Mhreimine Formation.

more than 880 ammonoid specimens were collected. In all 1.040 specimens are now available for study.

The aims of this study are to describe the Gara El Itima section and its ammonoid content in detail and to discuss the sedimentology as well as the biostratigraphy and biodiversity of the ammonoid assemblages.

\section{Sedimentary succession (C. K. \& S. D.) Geographic and geological setting}

The youngest Palaeozoic strata of the eastern Anti-Atlas are exposed in a wide syncline between the butte of Gara El Itima and the military post Hassi M'Rheimine (Fig. 1) near the Moroccan-Algerian frontier. Since the overall dip of the strata is very low and the rocks are mainly composed of siltstones and shales, outcrop conditions are generally poor to moderate. However, there are conspicuous ridges, which allow the sedimentological and palaeontological measurement, description, and collection of the Carboniferous rock succession in this area (Fig. 2). The strata are folded on a kilometre scale with
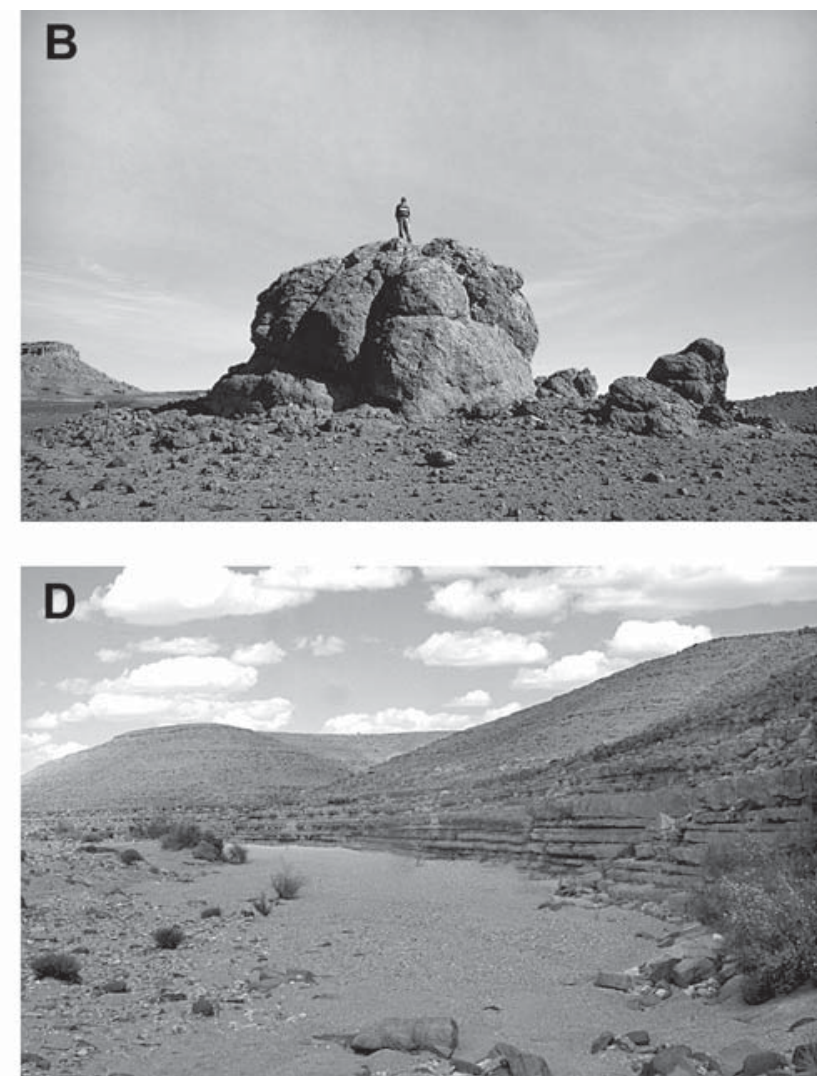


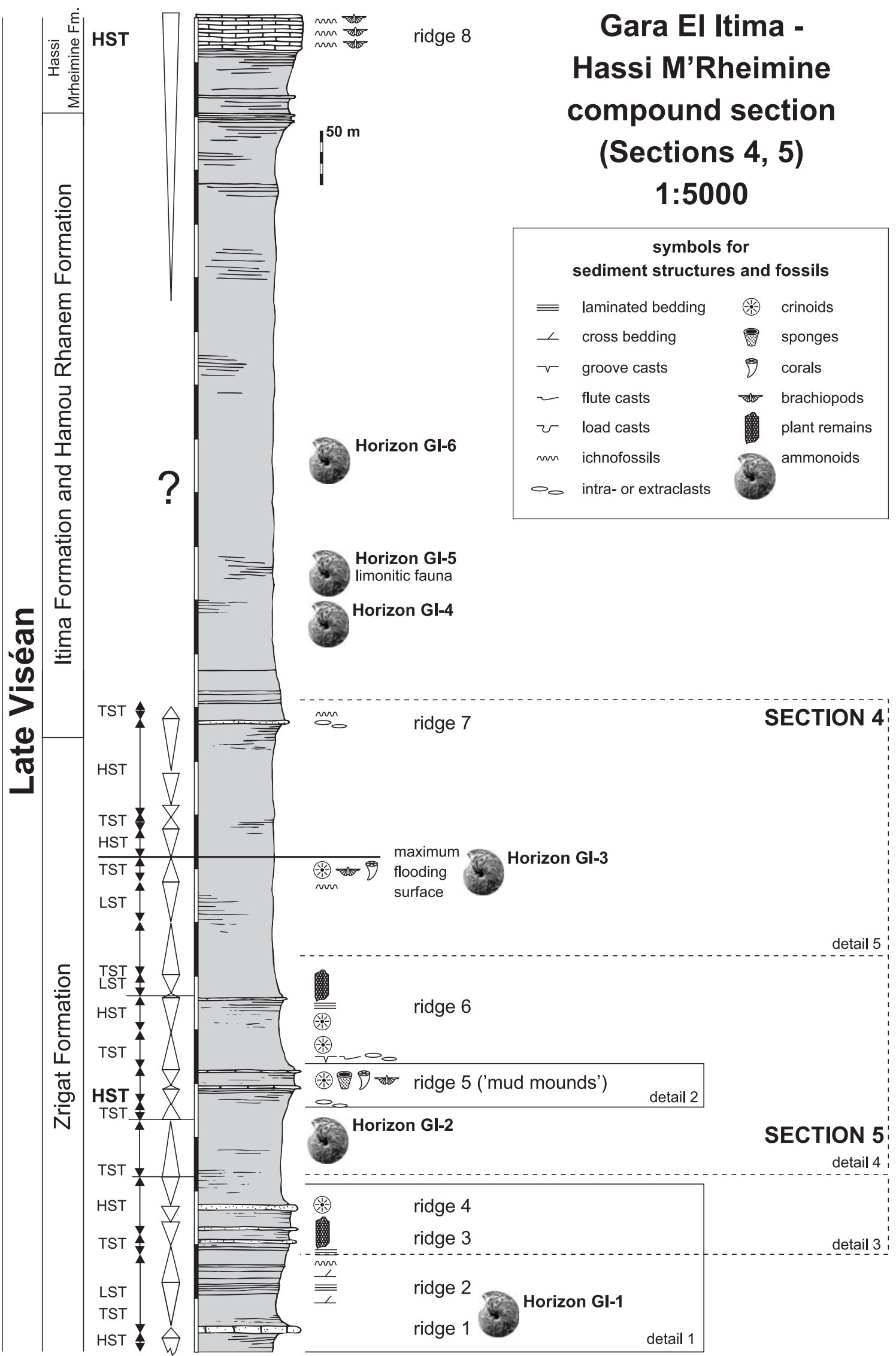

Fig. 3. Compound section of Gara El Itima and Hassi M'Rheimine, with approximate position of the detailed sections given in Figs 4 and 5. Note that this section contains information from various sections East of Gara el Itima (compare Fig. 1). This accounts for the sometimes significant discrepancies in thickness between the detailed sections and the compound section. Another problem was to achieve precise measurements of the dip and thus the thickness because of the weathering of the often shaly formations. 
fold axes mostly extending E-W with a slight inclination to the $\mathrm{S}$. Carboniferous strata $\mathrm{E}$ of the Gara El Itima strike E-W and dip between 5 and $20^{\circ}$ to the N. Near the centre of the syncline at Hassi M'Rheimine, these strata are almost horizontal (compare Destombes \& Hollard 1986). Undeformed, nearly flat-lying Late Cretaceous and Tertiary sedimentary rocks unconformably overlie the Carboniferous rocks. A transgressive conglomerate is usually present above this angular unconformity.

During various field trips, six parallel sections were measured. Among these, sections 4 and 5 were studied in more detail and are shown in figures $3-5$. Section 1 is the westernmost section. It lies directly south of the Aferdou Hamou Rhanem. Section 2 was measured northwest of the Gara El Itima and section 3 directly east of this butte. Section 5 is situated between Oued Bou Hamiane and Oued M'Rheimine. It begins $3.5 \mathrm{~km}$ east-southeast of Gara El Itima and ends $1.5 \mathrm{~km}$ west of Hassi M'Rheimine. Section 6 starts close to Hassi Talha and terminates approximately $1.5 \mathrm{~km}$ south-southwest of Hassi M'Rheimine. Sections 4 and 5 cover the widest stratigraphic range including the youngest strata in the Hassi M'Rheimine syncline and thus, the youngest strata of the Palaeozoic of the entire Tafilalt. In order to include at least moderately well exposed localities in the western section, it is composed of several segments, which are laterally displaced by 1 to $2 \mathrm{~km}$. This section yielded the majority of the data used for the composite section in figure 3 .

\section{Sedimentary succession}

Zrigat Formation - Approximately $2 \mathrm{~km}$ southeast of the Gara El Itima, a section of this formation is exposed. Since the quality of the exposure did not permit accurate logging farther to the $\mathrm{S}$, no older rocks have been studied at this locality. The $\log$ starts at a low ridge where a $7 \mathrm{~m}$ thick layer of fine-grained sandstones is exposed (ridge 1; GPS: $31^{\circ} 02^{\prime} 585^{\prime \prime} \mathrm{N}, 3^{\circ} 39^{\prime} 127^{\prime \prime} \mathrm{E}$, eastern section). The massive sandstones are overlain by $6 \mathrm{~m}$ of slightly micaceous, finegrained and thin-bedded sandstones. Above ridge 1 , about $150 \mathrm{~m}$ of poorly exposed shales and siltstones follow (see sections in Figs 3-5). About $60 \mathrm{~m}$ above ridge 1, several fine-grained sandstone horizons form an even E-W-trending elevation (ridge 2). These layers are thin to thick-bedded, show various types of bedding, trace fossils, as well as pot, flute, and groove casts. The following $45 \mathrm{~m}$ of strata are again poorly exposed shales and siltstones with some intercalated sandstone layers. On top of this unit, a conspicuous $40 \mathrm{~cm}$ thick layer of fine-grained sandy limestone forms the next ridge (ridge 3). Around $15 \mathrm{~m}$ above ridge 3 , ridge 4 follows which consists of $4 \mathrm{~m}$ of thick-bedded finegrained sandstones. The base of this sandstone succession contains clay lentils and yielded macroscopic plant remains up to $20 \mathrm{~cm}$ in length (Lepidodendron). The overlying $110 \mathrm{~m}$ of the section are poorly exposed. This suggests that the stratigraphic units are composed of rocks of smaller grain sizes with a higher clay content (siltstones and shales).

On top of this poorly exposed interval, two limestone beds occur, each up to several metres thick with intercalated silty shales (ridge 5; GPS $31^{\circ} 02^{\prime} 879^{\prime \prime} \mathrm{N}, 3^{\circ} 38^{\prime} 962^{\prime \prime} \mathrm{E}$ ). One shaly interval below and two shaly intervals above the "mudmound" layer (Wendt et al. 2001) yielded one ammonoid fauna each. The lower of the two limestones beds ("mudmounds") varies strongly in thickness and composition (Fig. 5). Occasionally, it is developed as a crinoid or oolitic bioclastic wacke-, grain- or packstone, sometimes with stromatactis cavities. These rocks contain crinoids, corals, sponges, bryozoans, brachiopods, and gastropods as the main biogenic components.

Above the oolithic-bioclastic limestone layer (Fig. 2B), there is a $30 \mathrm{~m}$ section of poorly exposed shales followed by a few intercalated thinbedded limestone and sandstone beds. Over these thin-bedded units, there is a $100 \mathrm{~m}$ thick shale with a few intercalated massive sandstone or limestone layers. This unit is topped by $10 \mathrm{~m}$ of limestone (ridge 6). Above the limestoneforming ridge 6 , there are about $100 \mathrm{~m}$ of shale, which is overlain by several up to $2 \mathrm{~m}$ thick limestone beds. The next $25 \mathrm{~m}$ of section are shaly and are capped by shale that contains a number of layers of sideritic nodules that yielded a wellpreserved ammonoid fauna including Dombarites granofalcatus (Kullmann, 1961), which was described by Korn et al. (1999). Above this ammonoid-bearing unit there are $6 \mathrm{~m}$ of thin-bedded limestones and marlstones forming the top of the overlying $26 \mathrm{~m}$ of shale in the succession. These lime- and marlstones are overlain by ca. $50 \mathrm{~m}$ of shales and a thick sandstone layer, which is overlain by $35 \mathrm{~m}$ of claystones and siltstones. At this point in the stratigraphic succession, the thickness of the layers increases simultaneously with 


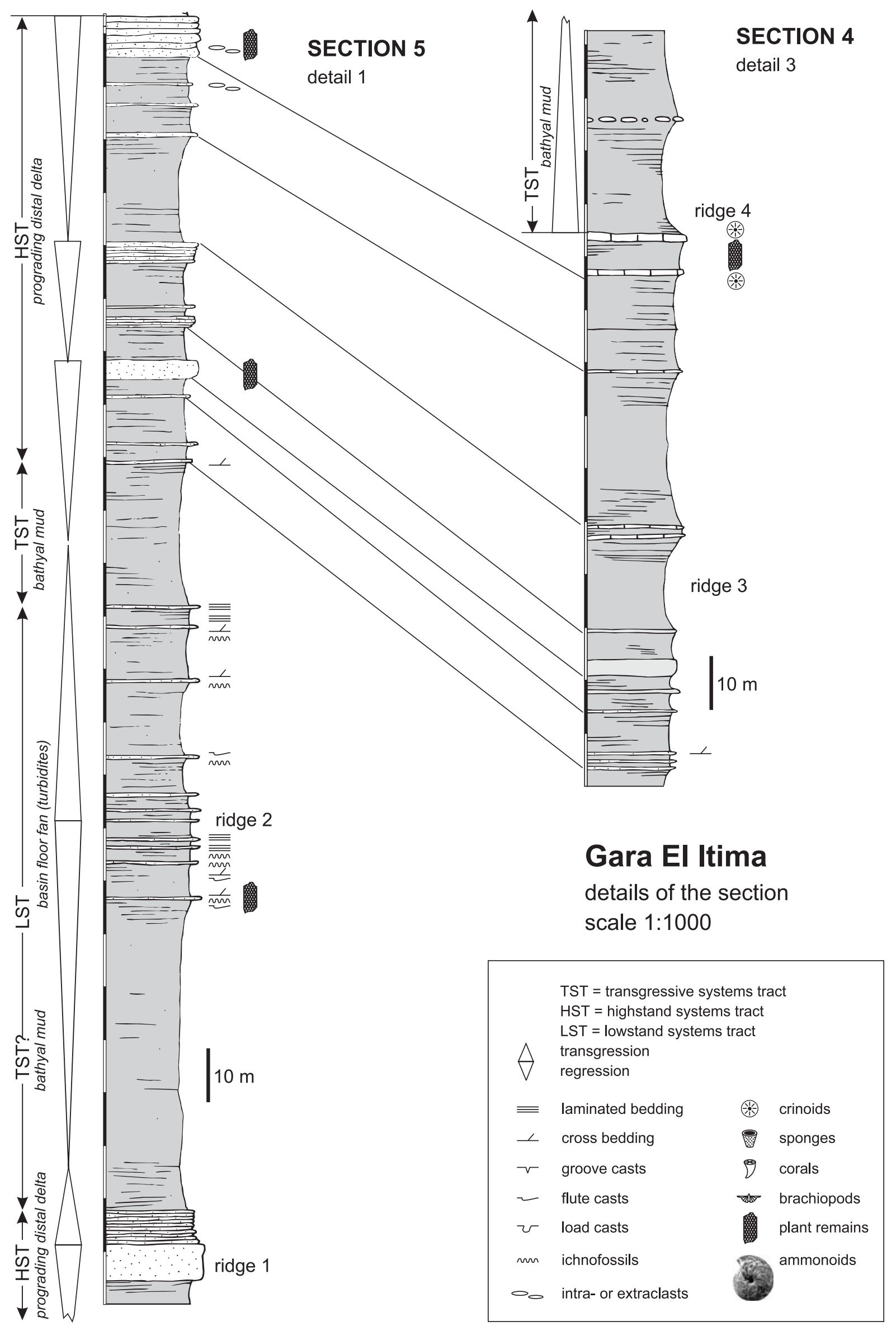

Fig. 4. Details of the lowest part of the section (all part of the Zrigat Formation) below the "mudmound" layer (ridges 1 to 4$)$. 


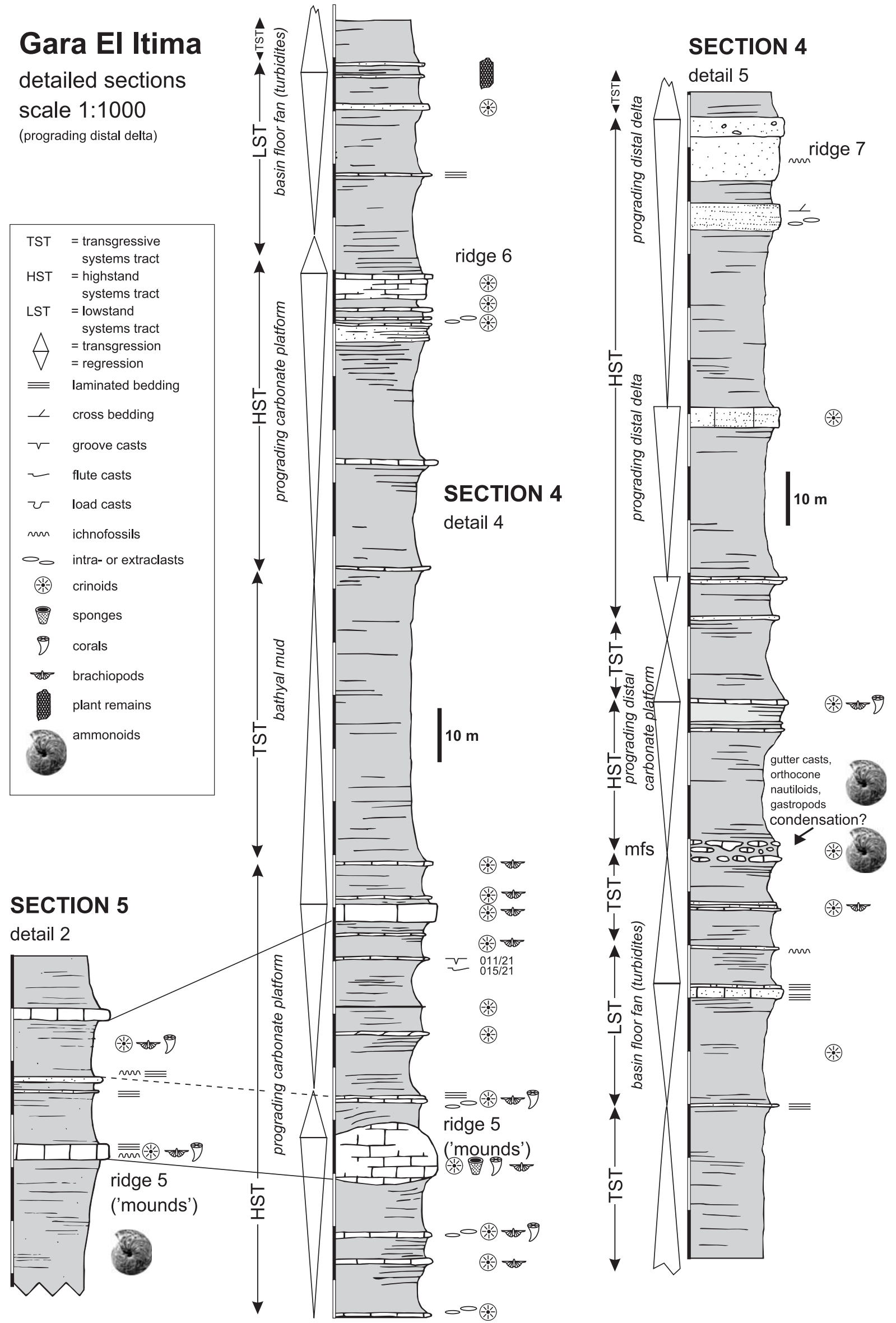

Fig. 5. Details of the part below the middle of the section (all part of the Zrigat Formation) below the "mudmound" layer (ridges 5 to 7 ). 
the grain size (thickening-upward). The $35 \mathrm{~m}$ of claystones and siltstones are capped by $21 \mathrm{~m}$ of sandstones that form ridge 7 , and this is the top of the Zrigat Formation.

Itima and Hamou-Rhanem Formations - The Itima and Hamou-Rhanem Formations consist of $500 \mathrm{~m}$ of poorly exposed shales overlying the sandstones of the Zrigat Formation. North of the Gara El Itima, this thick unit yielded a moderately rich limonitic ammonoid fauna (Fig. 2C).

Hassi Mrheimine Formation - The end of the section lies close to Hassi Mrheimine. There, a monotonous succession of approximately $100 \mathrm{~m}$ of moderately thin-bedded limestones is exposed (Fig. 2D). This interval contains more clay and siliciclastics at its base. The carbonate content rises significantly in the upper half of the section. The upper $30 \mathrm{~m}$ of the formation consist of a series of mudstone layers that are 5 to $50 \mathrm{~cm}$ thick and that contain abundant trace fossils (Planolites) and occasional spiriferid brachiopods.

\section{Discussion and interpretation}

The Carboniferous strata in the southeastern Tafilalt near the butte of Gara El Itima document a mixed carbonate-siliciclastic system. The sedimentary succession with its fauna, trace fossils and sedimentary structures indicates a mostly slope to base-of-slope environment, except for the uppermost part. For this part a position on the shelf is suggested because of the presence of almost $100 \mathrm{~m}$ of well-bedded limestones. Probable lowstands are documented by mixed siliciclastic-calcareous turbidites whereas highstands are mainly characterised by carbonate deposits. Highstand deposits display a distal facies of reworked carbonates or the distal portions of carbonate platforms. The most distal parts of the lower slope and the base-of-slope environments are represented by three thick shale intervals. These shales contain intercalated basin-floor fan deposits, (1) between ridge 1 and ridge 2, (2) above ridge 6 up to the overlying condensed interval with ammonoids, and (3) the thick shale succession above ridge 7 .

Zrigat Formation - The lowermost part of the section with predominantly siliciclastic deposits reflects the upper part of a regressive cycle (below and directly above ridge 1). These sandstones can thus be interpreted as the maximum progradation of a distal siliciclastic delta.
The subsequent transgression is recorded by an increase in clay content and the scarcity of fossil remains. Deposits on ridge 2 are interpreted as basin floor fan deposits because of their thickness and the sedimentary structures. As such, they mark a regression, which may indicate the existence of a lowstand wedge that formed during this time. Sediments deposited during a subsequent deepening are preserved in a thick interval of shales, which is overlain by the carbonates and siliciclastics of ridge 3 and 4 . These rocks are interpreted as remnants of a prograding siliciclastic delta with varying carbonate detritus content and may represent a highstand systems tract.

The composition of the overlying thick shale succession indicates a transgression that is followed by a regression as documented by the increasing amount of carbonate beds and the fossil content. The sediments of ridge 5 indicate erosion of carbonates somewhere in the $\mathrm{S}$ as indicated by various sole marks including gutter casts, tool marks, and groove casts. This mixture of carbonate and shale was redeposited in the deeper waters as storm deposits and/or calciturbidites, reflecting late-highstand conditions. This interval belongs lithostratigraphically to the Zrigat Formation, which is most probably of early Late Viséan age (Middle Viséan praebilineatus Zone, according to Wendt et al. 2001). The limestone beds contain relatively few marine invertebrates and form isolated carbonate bodies. Recently, some of these layers were interpreted as "mudmounds" by Wendt et al. (2001). According to these authors, approximately one hundred carbonate mud mounds of 4 different types are exposed in the area (Fig. 2A). Within the logged section, the type 4/D accumulations (ruditic channels) and locally type 2/B (crinoid limestones with stromatactis) are exposed (compare in Wendt et al. 2001). As mentioned by these authors, the presence of corals and questionable red algae indicates relatively shallow water, the thick under- and overlying shale deposits, however, indicate deposition below the storm-wave base. Accordingly, we assume that none of the "mudmounds" within the logged section is a true mudmound in contrast to some others in the region, which probably represent true mudmounds. We rather interpret, in concordance with Wendt et al. (2001), some of these structures as channels, filled with calcareous bioclastic and finegrained material and some of these as olistolithlike structures. As such, these carbonate bodies might correspond to the type $2 / \mathrm{B}$ mounds of 
Wendt et al. (2001). It is likely that these deposits correlate with carbonate mud mounds and reef-like structures of shallower-water environments as exposed in other parts of the region as well as in Algeria (Madi et al. 1993; Bourque et al. 1995; Sebbar \& Ait-Ouali 1996).

After deposition of these limestones, shale deposition prevailed, thus indicating a transgression and a subsequent highstand. Renewed carbonate deposition is preserved in ridge 6 and may reflect another late highstand. Subsequent transgression is documented by the following shale interval. The overlying carbonate beds with parallel lamination are resedimented limestones. As such they contain detrital quartz and are most probably related to a strong regression (lowstand systems tract). Shales above these rocks indicate transgression, which is then followed by shales containing sideritic nodules and cephalopod remains. It seems likely that the ammonoid-rich interval is a condensed section and represents a maximum flooding surface. The following regression finds its maximum in several limestone and marl beds with a diverse invertebrate fauna. These beds mark the maximum progradation of a carbonate platform during late highstand. After a transgressive interval, a highstand with multiple regressive phases is documented. The maximum progradation of the siliciclastic deposits (deltaics) is preserved in ridge 7 by coarsening upward sandstones with diverse sedimentary structures.

Itima and Hamou-Rhanem Formation - The rocks of the Zrigat Formation are followed by a thick transgressive succession consisting of monotonous shales $(\mathrm{ca} .500 \mathrm{~m})$. The water depth obviously increased, as there are fewer ridges with coarse clastic sediments. Similar to the lowermost part of the section, these sediments display characteristic features such as turbidites with the corresponding ichnofacies and sediment structures (sole marks, load casts, pot and gutter casts, current ripples). Destombes \& Hollard (1986) named these intervals the Itima and Hamou Rhanem Formations. Both formations are of Late Viséan age. Wendt et al. (2001) dated these two formations by conodonts as nodosa Zone.

Hassi Mrheimine Formation - The uppermost $100 \mathrm{~m}$ of the section consist of a monotonous limestone succession with some marl intercalations. Within this interval, abundant brachiopods and some trace fossils were found, indicating a relatively shallow water depth during the deposi- tion of this interval, thus suggesting a regression (late highstand). These carbonates belong lithostratigraphically to the Hassi Mrheimine Formation that has a possible Late Viséan or an early Serpukhovian age. Since the biostratigraphic data are poor and fossil remains and sedimentary structures are rare, the interpretation of the palaeoenvironment and the definition of the accurate stratigraphic position of this succession remain uncertain.

\section{Palaeontology of the ammonoids (D. K. \& V. E.)}

\section{Material}

More than 1.040 ammonoid specimens from 13 localities (GIA-GI-M) in the vicinity of the Gara el Itima are available for study. These specimens were recovered from six successive horizons, numbered herein GI-1-GI-6 in ascending order. These six horizons are distributed over a rock column thickness of approximately $1000 \mathrm{~m}$ (Figs 1,3). Because of the shallow inclination of the rocks with dips of $10-15^{\circ} \mathrm{N}$; single ammonoid-bearing horizons may be exposed for remarkable distances. Although almost entirely surface-collected, no mixing of the assemblages has been recognised. The lower two horizons are dominated by the genus Goniatites, and the upper four by Dombarites and Platygoniatites. Except for the specimens that were previously described by Korn et al. (1999) and stored in the Tübingen collection (IGT prefix), all the material is stored in the Museum für Naturkunde, Berlin, under the catalogue numbers MB.C.9031-MB.C.9097.

Locality GI-A is the site where C. K. and S. D. collected the first material in 1998 (Horizon GI-3). The material is stored in the Institut für Geowissenschaften, Tübingen University:

Sulcogirtyoceras sp. indet. (IGT 1851-90)

Hypergoniatites? sp. indet. $\quad$ (IGT 1851-91)

Dombarites granofalcatus $\quad$ (IGT 1851-93-95)

(Kullmann, 1961)

Prolecanites sp. indet.

(on IGT 1851-94)

same locality (coll. D. K. and C. K. 1999; 31 specimens):

Sudeticeras fornicum $\mathrm{n}$. sp. $\quad$ (MB.C.9033)

Neogoniatites worki n. sp. $\quad$ (MB.C.9032)

Dombarites granofalcatus $\quad$ (MB.C.3773, 3774,

(Kullmann, 1961)

9031.1-27)

same locality (coll. V. E. and D. K. 2004; 46 specimens):

Sudeticeras fornicum $\mathrm{n}$. sp. (MB.C.9034.1-4)

Neogoniatites worki $\mathrm{n}$. sp.

Neogoniatites? sp. indet.

(MB.C.9091.1-3)

Dombarites granofalcatus

(MB.C.9092)

(Kullmann, 1961)

(MB.C.9090.1-38)

Locality GI-B (coll. D. K. 1999; 5 specimens); Horizon GI-4: Sudeticeras pusillobatum n. sp. (MB.C.9036)

Platygoniatites rhanemensis n. sp. (MB.C.9035.1-4)

Locality GI-C (coll. D. K. 1999; 6 specimens); Horizon GI-2: Goniatites gerberi n. sp. (MB.C.9038)

Goniatites evelinae n. sp.

(MB.C.9037.1-5)

Locality GI-D (coll. C. K. 1999; 6 specimens); Horizon GI-5: dimorphoceratid indet. (MB.C.9043)

Hypergoniatites sp. indet. $\quad$ (MB.C.9040)

Dombarites sp. indet. ～(MB.C.9039.1-2)

Prolecanites sp. indet.

(MB.C.9042)

Epicanites sp. indet.

(MB.C.9041) 
Locality GI-E (coll. D. Weyer 2004; 11 specimens); Horizon GI-4:

Sudeticeras pusillobatum $\mathrm{n}$. sp.

Platygoniatites rhanemensis $\mathrm{n}$. $\mathrm{sp}$.

Prolecanites mapesi $\mathrm{n}$. $\mathrm{sp}$

Epicanites hamianensis $\mathrm{n}$. sp.
(MB.C.9045.1-5)

(MB.C.9044.1-3)

(MB.C.9046)

(MB.C.9047.1-2)

same locality (coll. V. E. 2003, 2004; 37 specimens)

Sudeticeras occultornatum n. $\mathrm{sp}$.

Sudeticeras pusillobatum $\mathrm{n}$. sp.

Neogoniatites worki $\mathrm{n}$. sp.

Platygoniatites rhanemensis $\mathrm{n}$. $\mathrm{sp}$.

Prolecanites mapesi $\mathrm{n}$. $\mathrm{sp}$

Epicanites hamianensis n. $\mathrm{sp}$.

Megapronorites itimensis $\mathrm{n}$. $\mathrm{sp}$.

(MB.C.9052.1-3)

(MB.C.9053.1-13)

(MB.C.9057)

(MB.C.9051.1-12)

(MB.C.9056)

(MB.C.9054.1-6)

(MB.C.9055)

same locality (coll. Z. S. Aboussalam and R. T. Becker 2003, 2004; 30 specimens)

Sudeticeras occultornatum n. sp.

Sudeticeras pusillobatum n. sp.

Neogoniatites? sp. indet.

Platygoniatites rhanemensis $\mathrm{n}$. $\mathrm{sp}$.

Epicanites hamianensis n. $\mathrm{sp}$.

Megapronorites itimensis $\mathrm{n}$. $\mathrm{sp}$.

(MB.C.9063)

(MB.C.9064.1-9)

(MB.C.9067)

(MB.C.9062.1-9)

(MB.C.9065.1-8)

(MB.C.9066.1-2)

Locality GI-F (coll. D. Weyer 2004; 4 specimens); Horizon GI-3:
Sudeticeras fornicum n. sp.
(MB.C.9050)
Neogoniatites worki $\mathrm{n}$. sp.
(MB.C.9049)
(MB.C.9048.1-2)
(Kullmann, 1961)

same locality (coll. Z. S. Aboussalam and R. T. Becker 2003, 2004; 3 specimens)
Dombarites granofalcatus
(Kullmann, 1961)
(MB.C.9068.1-3)

Locality GI-G (coll. V. E. 2003, 2004; 4 specimens); Horizon GI-2:

Goniatites gerberi n. sp.

Goniatites evelinae n. sp.

Goniatites stenumbilicatus

(MB.C.9059)

(MB.C.9058.1-2)

Kullmann, 1961

(MB.C.9060)

same locality (coll. Z. S. Aboussalam and R. T. Becker 2003, 2004; 10 specimens)
Goniatites evelinae n. sp.
(MB.C.9069.1-9)
Goniatites stenumbilicatus
(MB.C.9070)

Kullmann, 1961

Locality GI-H (coll. V. E. 2004; 1 specimen); Horizon GI-6: Dombarites bellornatus n. sp. (MB.C.9061)

same locality (coll. S. Kaiser, Z. S. Aboussalam, and R. T. Becker 2004; 5 specimens)

Dombarites bellornatus $\mathrm{n}$. $\mathrm{sp}$.

Ferganoceras torridum n. sp.

(MB.C.9072.1-4)

(MB.C.9071)

Locality GI-I (coll. V. E. and D. K. 2004; 690 specimens); Horizon GI-4:

Irinoceras sp. indet.

Sulcogirtyoceras sp. indet. 3

Sudeticeras pusillobatum $\mathrm{n}$. sp.

Sudeticeras occultornatum n. $\mathrm{sp}$.

Hypergoniatites fusiger $\mathrm{n}$. sp.

Neogoniatites worki $\mathrm{n} . \mathrm{sp}$.

Dombarites bellornatus $\mathrm{n}$. $\mathrm{sp}$

Platygoniatites rhanemensis n. sp.

Prolecanites mapesi $\mathrm{n}$. $\mathrm{sp}$.

Epicanites hamianensis n. sp.

Megapronorites itimensis $\mathrm{n}$. sp.
Locality GI-J (coll. V. E. and D. K. 2004; 87 specimens); Horizon GI-1:

Itimaites parabolicus n. $\mathrm{sp}$.

(MB.C.9086.1-2)

Calygirtyoceras zrigatense $\mathrm{n}$. $\mathrm{sp}$

(MB.C.9087.1-4)

Goniatites rodioni n. sp.

Prolecanites maeandricus $\mathrm{n}$. $\mathrm{sp}$.

(MB.C.9084.1-72)

(MB.C.9085.1-9)

Locality GI-K (coll. V. E. and D. K. 2004; 51 specimens); Horizon GI-2:
Goniatites gerberi $\mathrm{n}$. sp.
Goniatites stenumbilicatus
(MB.C.9088.1-50)
(MB.C.9089)

Kullmann, 1961

Locality GI-L (coll. V. E. and D. K. 2004; 5 specimens); Horizon GI-5:
Hypergoniatites fusiger $\mathrm{n} . \mathrm{sp}$.
Dombarites sp. indet.
Epicanites hamianensis $\mathrm{n}$. sp.
(MB.C.9095.1-2)
(MB.C.9096.1-2)
(MB.C.9094)

Locality GI-M (coll. V. E. and D. K. 2004; 7 specimens); Horizon GI-2:

Goniatites gerberi n. sp.

(MB.C.9097.1-7)

\section{Stratigraphic age of the assemblages}

The precise age determination of the six ammonoid-bearing horizons at the Gara el Itima is not a trivial problem. The occurrences belong to the Prototethyan Realm, and reference sections for such faunas are practically unknown. The betterknown ammonoid assemblages of Central and Northwestern Europe display a goniatite succession characterised by taxa not known from Morocco. Therefore, each ammonoid assemblage has to be discussed with respect to its composition, and will be compared with North Variscan as well as Prototethyan occurrences (Fig. 6).

Horizon GI-1 - Containing the crenistriate species Goniatites rodioni n. sp. together with the muensteroceratid Itimaites parabolicus n. $\mathrm{sp}$. and the rather simple girtyoceratid Calygirtyoceras zrigatense n. sp., an age interpretation of near the Crenistria Horizon of the Rhenish Mountains of Germany is most likely (Goniatites crenistria Zone in the German sections; P1a Zone in the British zonation). Horizon GI-1 is most probably younger than the two assemblages known from a locality $12 \mathrm{~km} \mathrm{~S}$ of the Dar Kaoua Oasis, which yielded one assemblage with Maxigoniatites saourensis (Pareyn, 1961), Beyrichoceras elabiodiense Korn et al., 1999, etc. (Korn et al. 1999), and another assemblage with Goniatites lazarus Korn et al., 2005 and Entogonites saharensis Korn et al., 2005, respectively (Korn et al. 2005).

Horizon GI-2 - It is quite possible that several distinct ammonoid horizons are artificially condensed here because of poor exposure. They are so closely related in terms of taxonomic composition and spatial relation, however, that they 


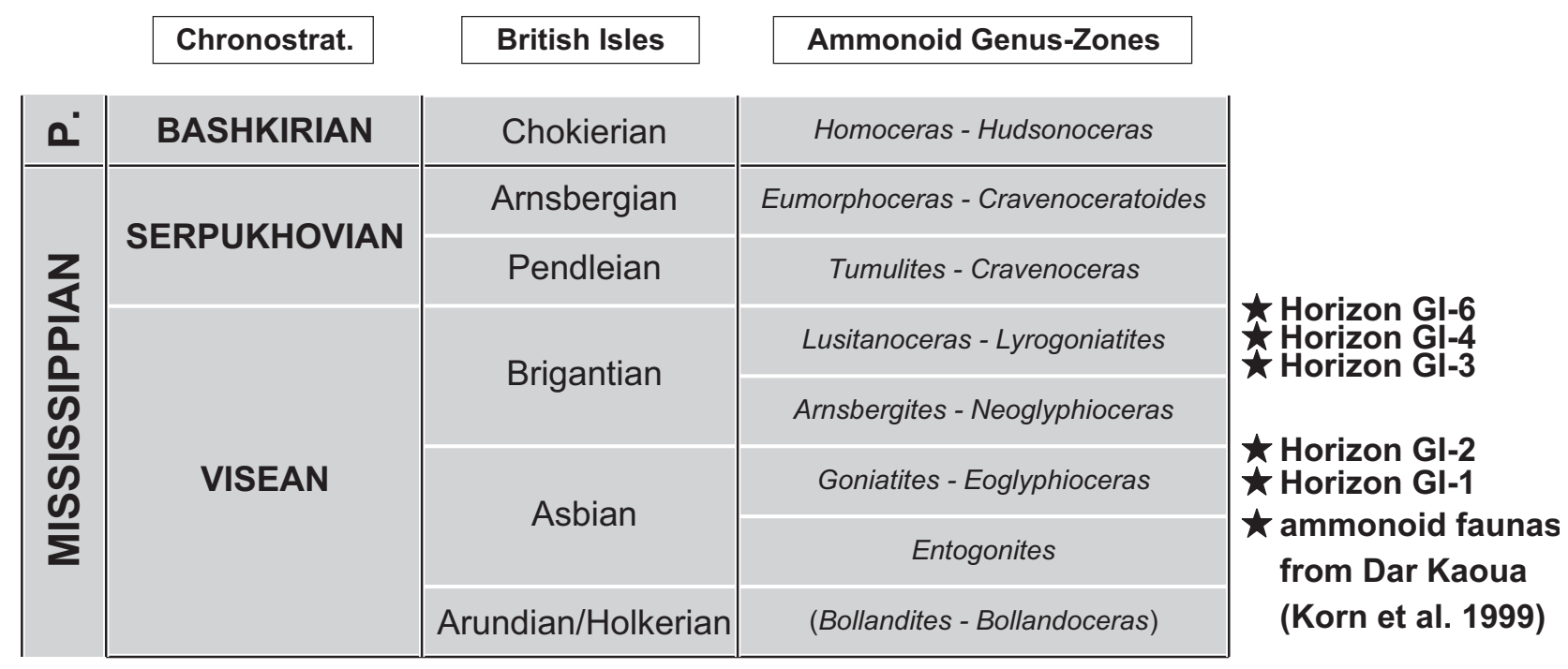

Fig. 6. Proposed stratigraphic position of the ammonoid assemblages from the Gara el Itima.

could not be separated in the surface collections. The three species of Goniatites have some similarities to spirally-ornamented species of that genus from other regions, e.g., the Cantabrian Mountains of Spain (because of the occurrence of G. stenumbilicatus - see Kullmann 1961), the northern Variscides of Germany and the British Isles (with the similar species G. spirifer - see Korn 1990), the American Midcontinent (G. multiliratus - see Gordon 1965), and the South Urals (G. crenifalcatus - see Bogoslovskaya 1966). This means that, in the area of Taouz, three stratigraphically successive species of Goniatites are recorded, a lower one with G. lazarus, a second one represented by Horizon GI-1 (G. rodioni n. sp.), and a third one in Horizon GI-2 (G. gerberi n. sp.).

Horizon GI-3 - The presence of Dombarites granofalcatus allows correlation with equivalent horizons in the Cantabrian Mountains of Spain, where this species occurs in a distinctive interval within the Alba Formation (Kullmann 1961). By contrast, there is no direct opportunity to correlate Horizon GI-3 with the North Variscides because Dombarites has not yet been recorded from this region. It is therefore largely a matter of speculation that Dombarites granofalcatus with a slightly more advanced suture line than in species of Lusitanoceras characterises a slightly higher stratigraphic position in the late Viséan.

It is worth mentioning that no ammonoids have been discovered between Horizons GI-2 and GI-3, a pattern difficult to explain. If the age determinations of GI-2 and GI-3 are correct, there would be a rather prominent missing record spanning at least five goniatite zones that are known from the Rhenish Mountains (Korn 1996). These five zones may be represented by the non-fossiliferous rock succession between GI-2 and GI-3. However, it may also be possible that the genus Goniatites ranges higher in the Prototethyan Realm. In that case, the Moroccan assemblage GI-2 would fall into the range of the genera Arnsbergites and Hibernicoceras of the North Variscides.

Horizon GI-4 - The most diverse ammonoid assemblage from the Gara El Itima yielded species from various superfamilies that are well-represented in the Cantabrian Mountains and the South Urals. The co-occurrence of rather early species of Dombarites and Platygoniatites with Hypergoniatites and Neogoniatites allows a correlation with the so-called "Nm1a Zone" of Ruzhencev \& Bogoslovskaya (1971) of the South Urals, probably equivalent to the highest Viséan of the Northern Variscides.

Horizon GI-5 - The poor assemblage with Hypergoniatites and Dombarites lies immediately above Horizon GI-4 and probably belongs to the same biozone.

Horizon GI-6 - Only Dombarites bellornatus and Ferganoceras torridum are available from this horizon; the latter indicates the "Nm1a Zone" of Ruzhencev \& Bogoslovskaya (1971), i.e., latest Viséan.

\section{Systematic descriptions}

Descriptive terms of the conch features are adopted from Korn (1988); abbreviations of the conch dimensions (Fig. 7) are: conch diameter (dm), whorl width (ww), whorl height (wh), umbilical width (uw), and aperture height (ah). A very important conch parameter is the whorl expansion rate (WER). It can be calculated by the algorithm used by Korn (2000): WER $=[\mathrm{dm} /(\mathrm{dm}-\mathrm{ah})]^{2}$. The imprint zone rate 


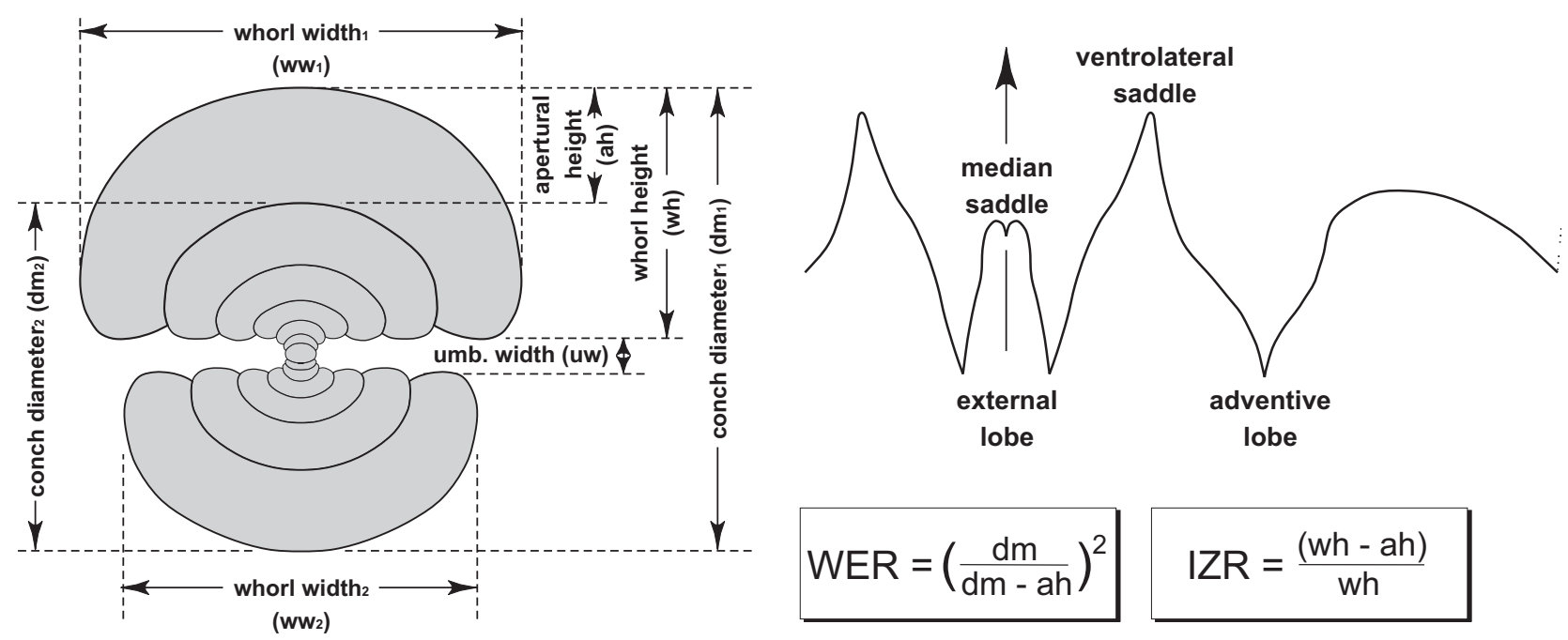

Fig. 7. Conch and suture parameters and ratios as used in the descriptions of the ammonoid species.

(IZR) is a ratio that characterises the whorl overlap. It can be calculated by the following equation: $\mathrm{IZR}=(\mathrm{wh}-\mathrm{ah}) /$ wh.

The material described and figured in the following account is stored in the cephalopod collection of the Museum für Naturkunde der Humboldt-Universität zu Berlin (MB.C. prefix), the Institut für Geowissenschaften, Universität Tübingen (IGT prefix), the British Geological Survey, Nottingham (Zx prefix), and the Ohio University Zoological Collections, Athens (OUZC prefix).

Superfamily Prionoceratoidea Hyatt, 1884 Family Prionoceratidae Hyatt, 1884

Subfamily Imitoceratinae Ruzhencev, 1950

\section{Irinoceras Ruzhencev, 1947}

Type species. Irinoceras arcuatum Ruzhencev, 1947.

\section{Irinoceras sp.}

Fig. 8

Material. Two fragments of specimens of approximately $60 \mathrm{~mm}$ conch diameter.

Locality and horizon. Gara el Itima, southeastern AntiAtlas, Morocco; Horizon GI-4 (basal Hamou-Rhanem Formation), probably latest Viséan.

Description. Specimen MB.C.9082.1 is the better preserved of the two fragments; it shows the characters typical for Irinoceras. It is thickly discoidal $(\mathrm{ww} / \mathrm{dm}=0.50)$ with closed umbilicus and possesses lamellose growth lines that run with a ventrolateral projection across the flanks and a deep sinus across the venter.

Superfamily Muensteroceratoidea Librovitch, 1957 Family Muensteroceratidae Librovitch, 1957

\section{Itimaites n. gen.}

Type species. Itimaites parabolicus n. sp.

Derivation of name. After the Gara el Itima, where the material was collected.

Genus definition. Genus of the Muensteroceratidae with striking ontogenetic changes. Juvenile stage pachyconic with wide umbilicus and low, depressed whorls; adult stage with narrow umbilicus and laterally compressed whorls. Suture line with narrow external lobe, broadly rounded ventrolateral saddle, and asymmetric adventive lobe.

Included species. Itimaites parabolicus n. sp.

Discussion. Itimaites is a genus that shares some characters with genera such as Eurites $\mathrm{Ku}-$ sina, 1973 and Eoglyphioceras Brüning, 1923. The shape of the inner whorls with broad venter and wide umbilicus closely resembles the first of these two genera, and also the suture line is rather similar. The adult conch and the ornament

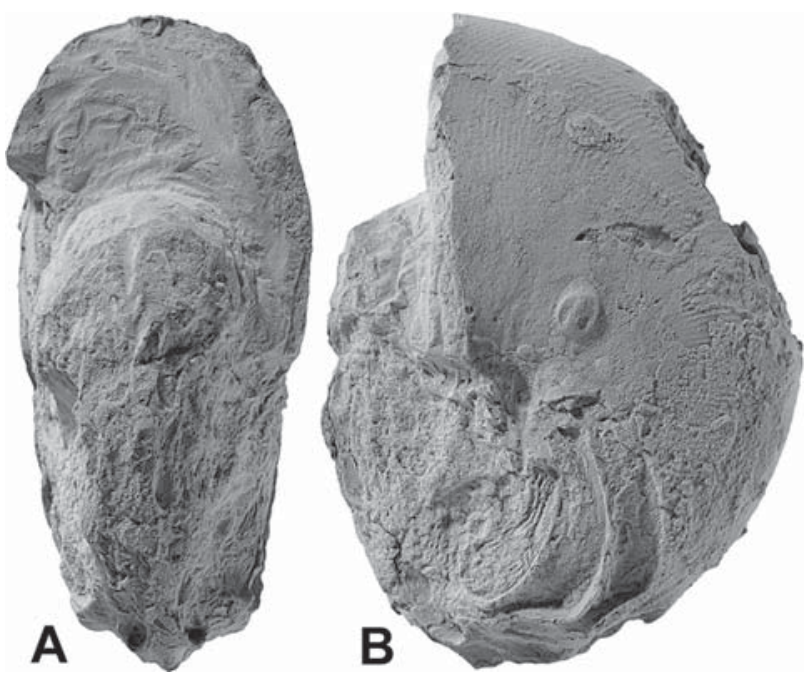

Fig. 8. Irinoceras sp. from Horizon GI-4 of the Gara el Iti$\mathrm{ma} ; \times 1$. A, B - specimen MB.C.9082.1. 
resembles more the latter genus, but the suture line is strikingly different.

Another genus that can be drawn for comparison is the late Tournaisian Ouaoufilalites Korn et al., 2003. This has a widely umbilicate, broad conch, but an adult stage with closure of the umbilicus and laterally compressed whorls is not known. The suture line of Ouaoufilalites, however, possesses an adventive lobe that is, in its asymmetric shape, very similar to Itimaites. Another criterion to separate the two genera is the laterally compressed adult stage of Itimaites, not known from Ouaoufilalites.

Stratigraphic occurrence. The assemblage from where the new genus is known belongs most probably in the late Viséan, but the precise age cannot be told. According to the co-occurrence with the new species Goniatites rodioni, a stratigraphic age near the mid-European Goniatites crenistria Zone is likely.

\section{Itimaites parabolicus $\mathbf{n}$. $\mathbf{s p}$.}

Figs 9, 10

Derivation of name. After the parabolic shape of the ventrolateral saddle.

Holotype. Specimen MB.C.9086.1 (coll. Ebbighausen and Korn 2004); figured here in Fig. 9A, B.

Type locality and horizon. Gara el Itima, southeastern Anti-Atlas, Morocco; Horizon GI-1 (Zrigat Formation), probably early part of the Late Viséan.

Material. Only the holotype and one additional paratype.

Diagnosis. Species of Itimaites with pachyconic, rather widely umbilicate conch at $20 \mathrm{~mm} \mathrm{dm}$ (ww/dm $=0.72$; uw/ $\mathrm{dm}=0.38)$ and discoidal, narrowly umbilicate conch at $50 \mathrm{~mm} \mathrm{dm}(\mathrm{ww} / \mathrm{dm}=0.45 ; \mathrm{uw} / \mathrm{dm}=0.15)$. Ventrolateral saddle symmetrically parabolic.

Description. Holotype MB.C.9086.1 is an incompletely preserved individual that allows a description of the late juvenile and adult mor-

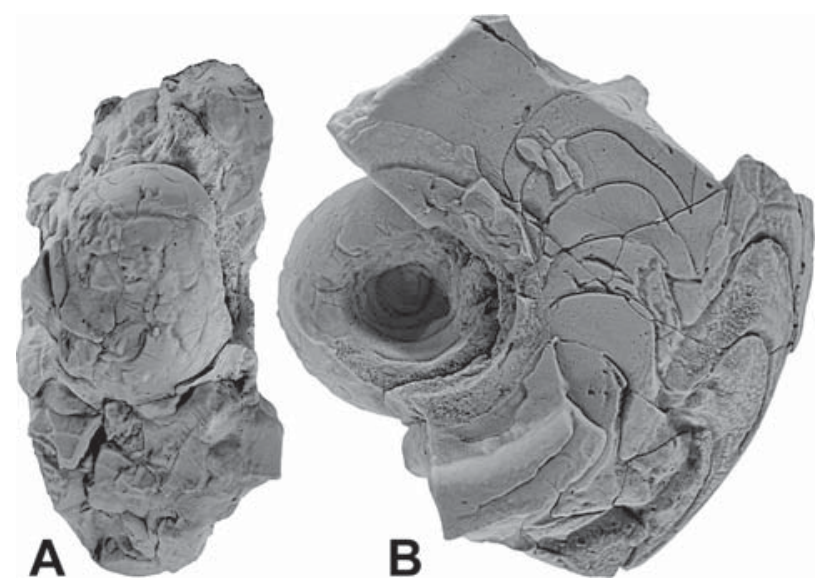

Fig. 9. Itimaites parabolicus n. sp. from Horizon GI-1 of the Gara el Itima; × 1. A, B - holotype MB.C.9086.1.

phology (Fig. 9A, B). There are conspicuous ontogenetic changes observable, with the inner whorls markedly differing from the outer. Up to $23 \mathrm{~mm} \mathrm{dm}$, there is a broad, rather widely umbilicate conch $(\mathrm{ww} / \mathrm{dm}=0.72 ; \mathrm{uw} / \mathrm{dm}=0.38)$ with a steep umbilical wall that is separated by a subangular margin from the flanks. The broad venter is widely rounded, and the aperture is obviously low $(\mathrm{ww} / \mathrm{wh}=2.10)$. This growth stage shows one linear steinkern constriction. Half a whorl later, at $36 \mathrm{~mm}$ conch diameter, there is a rapid increase of the apertural height, and the whorl expansion rate is 2.30. The whorl cross section is now laterally compressed. Again half a whorl later, at approximately $55 \mathrm{~mm}$ conch diameter, the conch is more compressed and the $\mathrm{ww} / \mathrm{dm}$ ratio may amount $0.45(\mathrm{ww} / \mathrm{wh}=0.83)$. The venter is narrowly rounded in this stage (Fig. 10C). The steinkern shows one constriction that extends with a rather deep sinus on the flank.

Two suture lines in different growth stages can be drawn from holotype MB.C.9086.1. In the inner whorls, at approximately $17 \mathrm{~mm}$ conch dia-
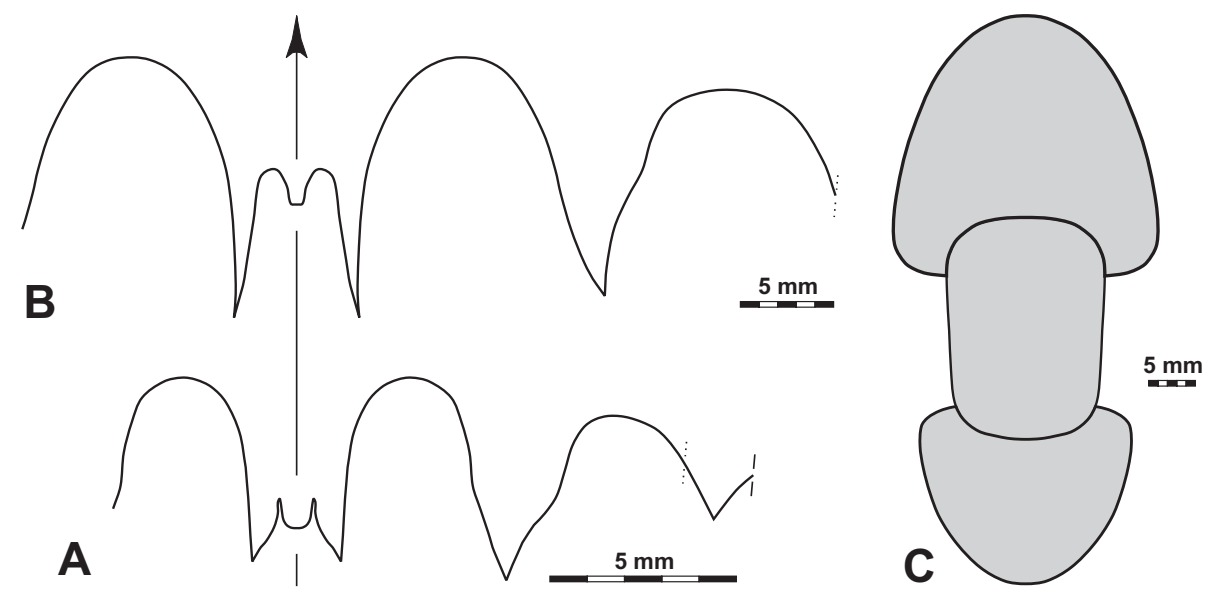

Fig. 10. Itimaites parabolicus n. sp. from Horizon GI-1 of the Gara el Itima. A - Suture line (reversed), holotype MB.C.9086.1, at ca. $17 \mathrm{~mm} \mathrm{dm}$, $14.2 \mathrm{~mm}$ ww, $7.1 \mathrm{~mm}$ wh; $\times 4$; B - Suture line (reversed), holotype MB.C.9086.1, at ca. $55 \mathrm{~mm} \mathrm{dm}, 24.8 \mathrm{~mm}$ ww, $21.5 \mathrm{~mm}$ wh; $\times 2$; C - Reconstruction of the whorl outline, holotype MB.C.9086.1; × 1 . 
meter, there is a narrow external lobe with almost parallel flanks. The width/height ratio of this lobe is 0.55 , and the median saddle reaches 0.34 of the external lobe depth. On the flanks follows a broadly rounded, almost symmetric ventrolateral saddle that is wider than the external lobe. The asymmetric $\mathrm{V}$-shaped adventive lobe has an almost linear ventral and a sinuous dorsal flank (Fig. 10A).

One whorl later, a significantly different suture line can be seen. The external lobe has a narrower outline (width/height ratio $=0.52$ ) with concave flanks, and the median saddle experienced a remarkable heightening to a value of 0.57 of the external lobe depth. The parabolic ventrolateral saddle is still broadly rounded and almost 1.5 times wider than the external lobe (Fig. 10B). It is remarkable that the shape of the adventive lobe, asymmetric with sinuous dorsal flank, closely resembles the earlier ontogenetic stage.

Discussion. Obviously, there is no other ammonoid known that could be confused with the new species. The adult conch may look like a species of Eoglyphioceras, but the widely umbilicate inner whorls are very dissimilar.

Family Girtyoceratidae Wedekind, 1918

\section{Calygirtyoceras Korn et al., 1999}

Type species. Calygirtyoceras darkaouaense Korn et al., 1999.

\section{Calygirtyoceras zrigatense $\mathbf{n}$. sp.}

Figs 11, 12

Derivation of name. After the Zrigat mudmound chain, and the Formation in which the new species was found.
Holotype. Specimen MB.C.9087.1 (coll. Ebbighausen and Korn 2004); figured here in Fig. 11A, B.

Type locality and horizon. Gara el Itima, southeastern Anti-Atlas, Morocco; Horizon GI-1 (Zrigat Formation), probably early part of the Late Viséan.

Material. Four specimens are available; two of these in an intermediate stage $(40 \mathrm{~mm} \mathrm{dm})$, one large specimen of $65 \mathrm{~mm}$ conch diameter, and one strongly weathered whorl fragment.

Diagnosis. Species of Calygirtyoceras with discoidal conch at $40 \mathrm{~mm}$ diameter (ww/dm 0.40); umbilicus moderate (uw/ $\mathrm{dm}$ 0.25). Transition into the oxyconic stage at $45 \mathrm{~mm}$ conch diameter; umbilical wall subangular. Shell with fine growth lines with biconvex and rursiradiate course.

Description. Holotype MB.C.9087.1 displays the morphology of the adult conch, i.e., at the transition from the discoidal to the oxyconic stage (Fig. 11A, B). The slightly crushed last half whorl possesses a ventral keel that is best developed at the maximum diameter of $65 \mathrm{~mm}$. At the beginning of the last whorl, there is still a rounded venter. The umbilical wall is steep in the specimen, and the umbilical margin is subangular. There are no shell remains preserved in the specimen, and the steinkern is almost completely smooth. Only the last quarter of the adult whorl bears some shallow, short constrictions at the place where the ventrolateral projection of the growth lines is located.

The smaller paratype MB.C.9087.3 displays the preadult morphology at $39 \mathrm{~mm}$ conch diameter (Fig. 11C, D). It is a discoidal conch (ww/ $\mathrm{dm}=0.41$ ) with moderate umbilicus (uw/ $\mathrm{dm}=0.26$ ). The venter is rounded in this growth stage, and the flanks stand subparallel. A subangular umbilical margin is present, and the umbilical wall is steep. Delicate growth lines cover the shell surface; they run slightly rursiradiate with a wide projection on the inner flank, a low ventrolateral projection, and a rather deep ventral sinus. There are no shell constrictions in this growth stage. The growth lines become continuously finer during the last preserved whorl.
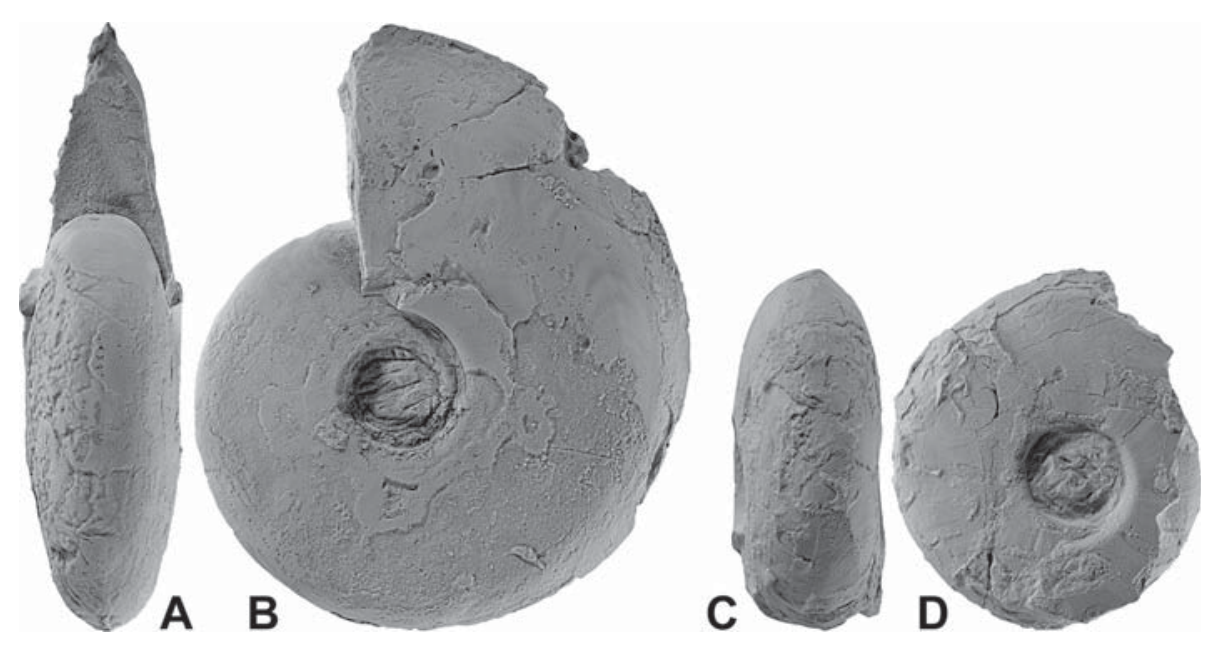

Fig. 11. Calygirtyoceras zrigatense n. sp. from Horizon GI-1 of the Gara el Itima; all $\times 1$. A, B - holotype MB.C.9087.1; C, D - paratype MB.C.9087.3. 


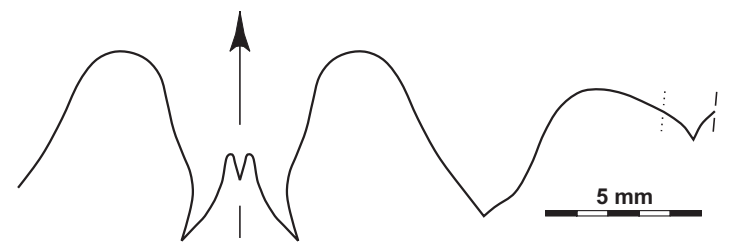

Fig. 12. Calygirtyoceras zrigatense n. sp. from Horizon GI-1 of the Gara el Itima. Suture line, paratype MB.C.9087.2, at $16.2 \mathrm{~mm}$ ww, $11.8 \mathrm{~mm}$ wh; $\times 3.5$.

The suture line can be studied in the stouter paratype MB.C. 9087.2 at $16 \mathrm{~mm}$ whorl width; it is characteristic for a girtyoceratid species. The V-shaped external lobe possesses hooke-shaped prongs, and its flanks are strongly sinuous. On the flank follow a rounded ventrolateral saddle and an asymmetric, V-shaped adventive lobe (Fig. 12).

Discussion. The new species differs from the other Moroccan species C. darkaouaense Korn et al., 1999 in the much narrower conch that is pachyconic in C. darkaouaense ( $\mathrm{ww} / \mathrm{dm}=0.70$ at $21 \mathrm{~mm} \mathrm{dm}$ ). This species has much finer growth lines than C. zrigatense. C. moorei (Nicolaus, 1963) has a narrower conch than $C$. zrigatense and a narrower umbilicus (uw/dm $=0.20$ at $19 \mathrm{~mm} \mathrm{dm})$. The course of the growth lines is rectiradiate with prominent ventrolateral projection in C. moorei, in contrast to the backward oriented growth lines in C. zrigatense.

A similar species is C. arcticum (Gordon, 1957), but this species has prorsiradiate growth lines. C. platyforme (Moore, 1946) may also belong to the genus; it has a much narrower conch than the new species.

\section{Sulcogirtyoceras Ruzhencev, 1960}

Type species. Eumorphoceras Burhennei Brüning, 1923.

\section{Sulcogirtyoceras sp.}

Fig. 13

Material. 4 specimens between 30 and $45 \mathrm{~mm}$ conch diameter.

Locality and horizon. Gara el Itima, southeastern AntiAtlas, Morocco; Horizon GI-4 (basal Hamou-Rhanem Formation), probably latest Viséan.

Description. Specimen MB.C.9073.1 was cut for a cross section. Although not completely preserved, it shows the transition into the oxyconic adult form that begins at approximately $25 \mathrm{~mm}$ conch diameter. The inner whorls are very wide umbilicate. All visible growth stages between 10

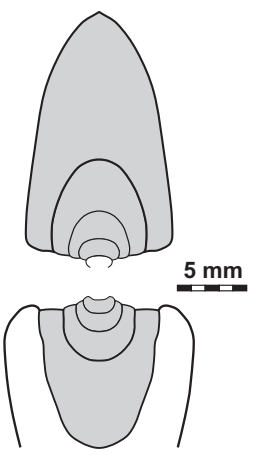

Fig. 13. Sulcogirtyoceras sp. from Horizon GI-4 of the Gara el Itima. Cross section, specimen MB.C.9073.1; × 1.5.

and $32 \mathrm{~mm} \mathrm{dm}$ possess a pronounced, sometimes subangular umbilical margin (Fig. 13).

Discussion. Since the material is only poorly preserved, a species description is impossible. From the shape of the inner whorls it is clear, however, that the material has to placed into Sulcogirtyoceras.

\section{Family Sudeticeratidae n. fam.}

Family definition. Family of the Muensteroceratoidea with wide, usually V-shaped external lobe. Conch usually thickly discoidal or pachyconic with very narrow umbilicus in the adult stage.

\section{Sudeticeras Patteisky, 1930}

Type species. Homoceratoides Hoeferi Patteisky, 1929.

\section{Sudeticeras fornicum n. sp.}

Figs 14, 15

Derivation of name. After the Latin fornicis $=$ arched, because of the convex flanks of the conch.

Holoty pe. Specimen MB.C.9050 (coll. Weyer 2004); figured here in Fig. 14A, B.

Type locality and horizon. Gara el Itima, southeastern Anti-Atlas, Morocco; Horizon GI-3 (uppermost Zrigat Formation), latest Viséan.

Material. Six specimens between 22 and $72 \mathrm{~mm}$ conch diameter.

Diagnosis. Species of Sudeticeras with pachyconic conch at $20 \mathrm{~mm}$ diameter $(\mathrm{ww} / \mathrm{dm}=0.65)$ and thickly discoidal conch $(\mathrm{ww} / \mathrm{dm}=0.55)$ at $50 \mathrm{~mm}$ diameter. Flanks slowly converging towards the venter; conch is thickest in some distance from the umbilicus. Umbilicus very narrow in all stages larger than $20 \mathrm{~mm} \mathrm{dm}$ (uw/dm increasing from 0.05-0.12). Ornament with crenulated biconvex and rectiradiate growth-lines with prominent ventral sinus. Suture line with rather wide external lobe ( 0.65 of the external lobe depth; 1.45 of adventive lobe width), and moderately high median saddle ( 0.45 of the external lobe depth).

Description. The morphometric analysis of the few specimens must be limited, but it is clear that the ontogenetic changes are characteristic 

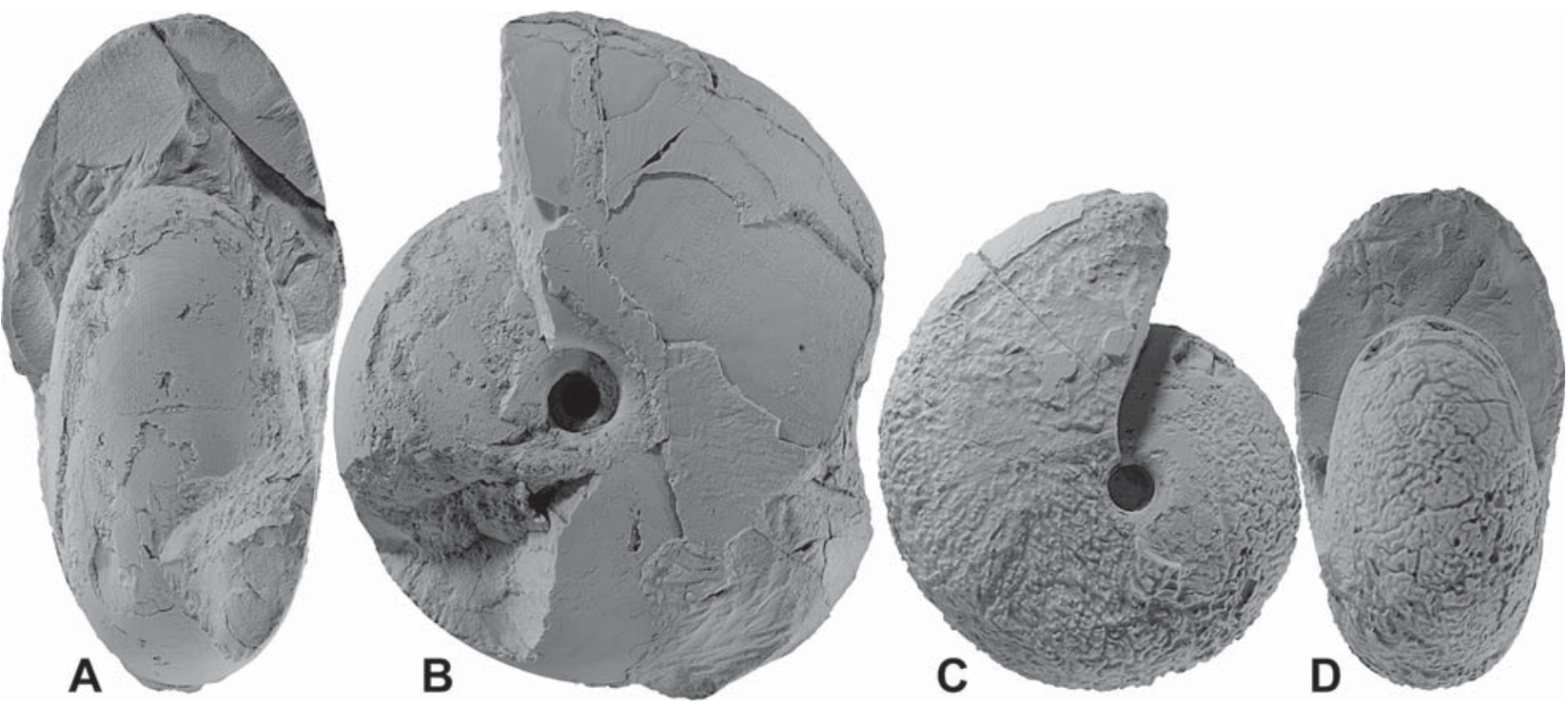

Fig. 14. Sudeticeras fornicum n. sp. from Horizon GI-3 of the Gara el Itima; all $\times 1$. A, B - holotype MB.C.9050; C, D paratype MB.C.9093.1.

for the genus. In stages larger than $20 \mathrm{~mm}$ conch diameter, the conch becomes thinner and the umbilicus wider. In this interval, the whorl expansion rate decreases from approximately 2.00 to 1.75 .

The largest specimen (holotype MB.C.9050) is thickly discoidal at $72 \mathrm{~mm}$ conch diameter (ww/ $\mathrm{dm} 0.50)$, and the whorl width equals the whorl height. A narrow umbilicus $(\mathrm{uw} / \mathrm{dm}=0.12)$ is bordered by a rounded margin from the flanks that converge to the broadly rounded venter (Fig. 14A, B). An unusual character for a mem- ber of the genus Sudeticeras is the fact that the conch is not widest at the umbilical margin, but in some distance, i.e., at the inner third of the flank. The aperture is rather low with a whorl expansion rate of 1.75 . Shell remains are preserved in a patchy manner; there are weakly crenulated, irregularly spaced growth lines running with a biconvex course and form a low ventrolateral projection and a rather deep ventral sinus. Spiral lines are developed in a narrow zone around the umbilicus and on the venter.
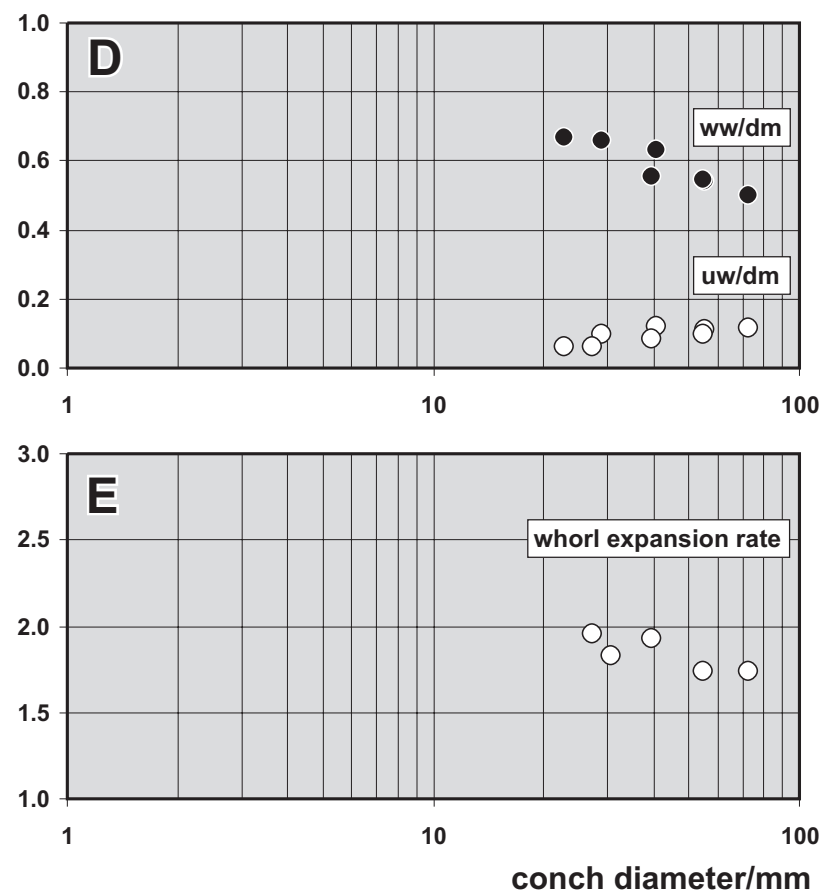

Fig. 15. Sudeticeras fornicum n. sp. from Horizon GI-3 of the Gara el Itima. A - Suture line (reversed), paratype MB.C.9093.2, at $15.6 \mathrm{~mm}$ ww, $10.2 \mathrm{~mm}$ wh; $\times 2$; B - Suture line, paratype MB.C.9093.1, at $23.0 \mathrm{~mm}$ ww, $17.5 \mathrm{~mm}$ wh; $\times 1.5$; C - Suture line, holotype MB.C. 9050 , at $30.2 \mathrm{~mm}$ ww, $23.5 \mathrm{~mm}$ wh; $\times 1.5 ; \mathbf{D}$ - Ontogenetic development of the whorl width index (ww/dm) and umbilical width index (uw/dm); E - Ontogenetic development of the whorl expansion rate (WER). 
An intermediate specimen (paratype MB.C.9093.1) has, at $54 \mathrm{~mm}$ diameter, similar conch ratios, but is a little stouter. The growth lines of this specimen extend with the same course as in the preceding specimen, but spiral lines are lacking (Fig. 14C, D).

Paratype MB.C.9093.2 is, with $39 \mathrm{~mm}$ diameter, one of the smaller available individuals; its conch is thinner than the others and has a higher aperture (WER $=1.94)$. The shell appears to be smooth in this specimen.

Three suture lines were drawn from the specimens described above. The suture lines of the two smaller specimens MB.C.9093.2 (at ww $=15.6 \mathrm{~mm}$ ) and MB.C.9093.1 (at $\mathrm{ww}=23 \mathrm{~mm}$ ) resemble each other, and display the characteristic outline of Sudeticeras (Fig. 15A, B). The latter specimen has a wide external lobe ( 0.67 of the lobe depth) and a moderately high median saddle ( 0.47 of the external lobe depth). The flanks of the external lobe diverge towards the narrowly rounded ventrolateral saddle, and the symmetric, Vshaped adventive lobe has gently curved flanks. The adventive lobe is almost as deep as the external lobe.

The large holotype MB.C.9050 displays a mature modification of the suture line (Fig. 15C). The external lobe is Y-shaped, caused by flanks that strongly diverge in the upper half of the lobe. By this reason, the ventrolateral saddle is strikingly asymmetric.

Discussion. The other two species of Sudeticeras described here differ from S. fornicum in their higher aperture in comparable growth stages. Between 50 and $70 \mathrm{~mm}$ conch diameter, the whorl expansion rate reaches only 1.75 in $S$. fornicum, whereas it ranges between 1.85 and 2.05 in S. pusillobatum and S. occultornatum. The suture line of these two species possesses an external lobe that is much larger and deeper than in S. fornicum.

S. grande Ruzhencev \& Bogoslovskaya, 1971 has a narrower umbilicus; the uw/dm ratio amounts 0.05 between 15 and $55 \mathrm{~mm}$ conch diameter $(0.08-0.12$ in $S$. fornicum). The aperture is higher in S. grande (WER $=1.95$ at $50 \mathrm{~mm}$ $\mathrm{dm})$. Furthermore, S. grande has a wider external lobe. More similar is S. karagandense Ruzhencev \& Bogoslovskaya, 1971, but this species has also a wider external lobe with stronger diverging flanks. In this character, most of the species of Sudeticeras, such as S. varians (Bisat, 1950), S. turneri Moore \& Hodson, 1958, and S. murracaoense Korn, 1997 differ from the new species.
A full comparison with the species of Sudeticeras from the northern Variscides is difficult because many of these species are insufficiently described or are based on poorly preserved material. Therefore, a number of species cannot be discussed in the context of the new Moroccan species.

\section{Sudeticeras pusillobatum n. sp.}

Figs 16, 17

Derivation of name. After the Latin pusillus = small, because of the small adventive lobe.

Holotype. Specimen MB.C.9064.1 (coll. Aboussalam and Becker 2004); figured here in Fig. 16A, B.

Type locality and horizon. Gara el Itima, southeastern Anti-Atlas, Morocco; Horizon GI-4 (basal Hamou-Rhanem Formation), probably latest Viséan.

Material. 107 specimens between 18 and $65 \mathrm{~mm}$ conch diameter.

Diagnosis. Species of Sudeticeras with pachyconic conch at $20 \mathrm{~mm}$ diameter $(\mathrm{ww} / \mathrm{dm}=0.60-0.65)$ and thickly discoidal conch $(w w / d m=0.55-0.60)$ at $50 \mathrm{~mm}$ diameter. Flanks converging towards the venter; the conch is thickest near the umbilicus. Umbilicus wide in the juvenile stage, and very narrow in all stages larger than $10 \mathrm{~mm} \mathrm{dm}$ (uw/dm constantly between 0.05 and 0.12 ). Ornamentation with crenulated biconvex and rectiradiate growth-lines with low ventral sinus. Fine spiral lines around the umbilicus and on the venter. Suture line with wide external lobe $(0.70$ of the external lobe depth; 1.45 of adventive lobe), and high median saddle (more than 0.50 of the external lobe depth). Ventrolateral saddle narrowly rounded or subacute; adventive lobe shorter than the external lobe.

Description. More than 130 data sets are available to describe the morphometric development of the conch (Fig. 17E, F). A clearly visible ontogenetic trend is the continuous decrease of the ww/dm ratio; at $20 \mathrm{~mm} \mathrm{dm}$ this lies between 0.60 and 0.65 , and at $50 \mathrm{~mm} \mathrm{dm}$ between 0.55 and 0.60. After a widely umbilicate juvenile stage, there is a stagnation in the uw/dm ratio; this value usually ranges between 0.05 and 0.12 . The WER performs a rather rapid juvenile increase (up to 2.00 at $10 \mathrm{~mm} \mathrm{dm}$ ); thereafter, this value is maintained throughout later ontogeny. In most specimens, it lies between 1.90 and 2.10.

The cross section of specimen MB.C.9077.1 displays distinct ontogenetic stages, when the three characters whorl width index, umbilical width index, and whorl expansion rate are observed up to a maximum diameter of $40 \mathrm{~mm}$ (Fig. 17B). All of these show two stages, but these are, in their length, hardly correlated. The first stage of the ww/dm ratio is characterised by a value of 0.80 (up to $6 \mathrm{~mm} \mathrm{dm}$ ), followed by a continuous decrease to 0.54 at $40 \mathrm{~mm} \mathrm{dm}$. The uw/dm ratio has an early juvenile value of 0.35 

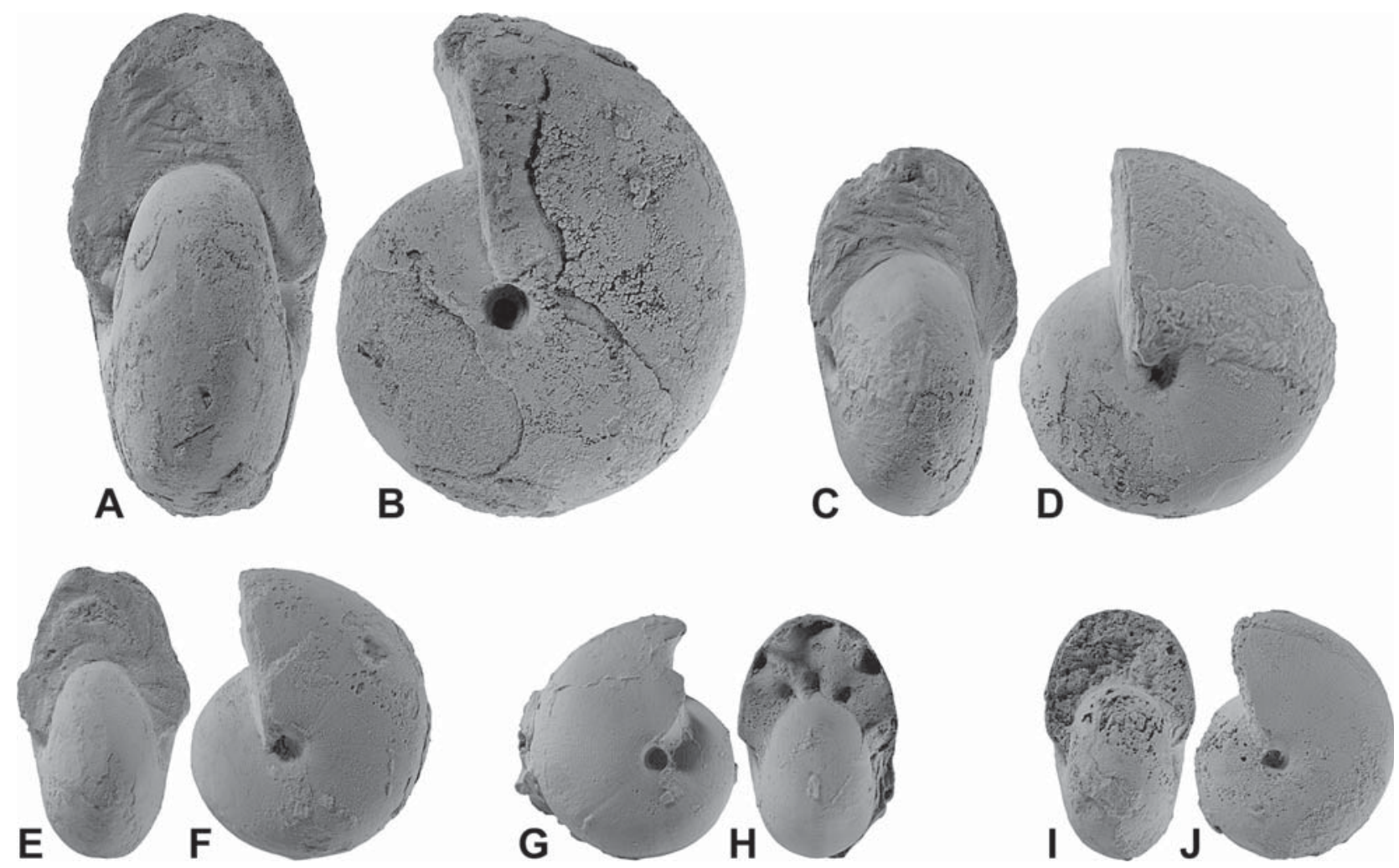

Fig. 16. Sudeticeras pusillobatum n. sp. from Horizon GI-4 of the Gara el Itima; all $\times 1$. A, B - holotype MB.C.9064.1; C, D - paratype MB.C.9077.2; E, F - paratype MB.C.9077.3; G, H - paratype MB.C.9077.5; I, J - paratype MB.C.9077.8.

at $1-3 \mathrm{~mm} \mathrm{dm}$, followed by a lowering to less than 0.10 in preadult and adult stages. A third trend can be seen in the WER, where after a juvenile stagnation around 1.75 , a heightening to more than 2.10 can be observed in the mature conch.

Holotype MB.C.9064.1 displays the conch morphology and, in some parts, the ornament of the adult conch (Fig. 16A, B). The conch has, at $61 \mathrm{~mm}$ diameter, a thickly discoidal shape (ww/ $\mathrm{dm}$ little more than 0.50 ) with very narrow umbilicus (uw/dm $=0.07$ ). The conch is thickest at the umbilical wall, from where the flanks converge towards the broadly rounded venter. Some shell remains are visible, they show delicate spiral lines around the umbilicus and in the ventral area.

Spiral lines are visible in several of the better preserved specimens. In the paratypes with approximately $40 \mathrm{~mm} \mathrm{dm}$ (such as MB.C.9077.2; Fig. 16C, D), they may also be restricted to the venter, but in others, such as MB.C.9077.3 (35 $\mathrm{mm} \mathrm{dm})$ and MB.C.9077.4 (50 $\mathrm{mm} \mathrm{dm})$, they are visible on flanks and venter (Fig. 16E, F). Smaller specimens tend to show the spiral ornament more often. The smaller specimen MB.C. 9077.8 has, at $30 \mathrm{~mm}$ diameter, rather strong, crenulated growth lines that run with a biconvex course, forming a very shallow lateral sinus and a deeper ventral sinus, cross flanks and venter. Fine spiral lines cross the growth lines (Fig. 16I, J).

A well-preserved individual is paratype MB.C.9077.5 (30 mm conch diameter). It is thinly pachyconic $(\mathrm{ww} / \mathrm{dm}=0.62)$ and widest at the umbilicus, from where the flanks converge towards the broadly rounded venter (Fig. 16G, H). The shell is somewhat smoothed by aeolian erosion, but displays rather course, crenulated growth lines at the end of the preserved volution. These run in slightly forward direction with almost linear course across the flanks and bend back to form a wide and shallow ventral sinus. Another element of the ornament are fine spiral lines, of which approximately 120 cover flanks and venter.

The adult suture line (paratype MB.C.9077.6; $36 \mathrm{~mm} \mathrm{dm}$ ) is characteristic for its high median saddle (more than 0.50 of the external lobe depth) and the subacute ventrolateral saddle (Fig. 17D). The general outline of the external lobe is Y-shaped with strongly diverging flanks. The smaller specimen MB.C.9077.7 has, at approximately $25 \mathrm{~mm} \mathrm{dm}$, a suture line that has a much lower median saddle ( 0.37 of the external lobe depth). This stage shows already a narrowly 


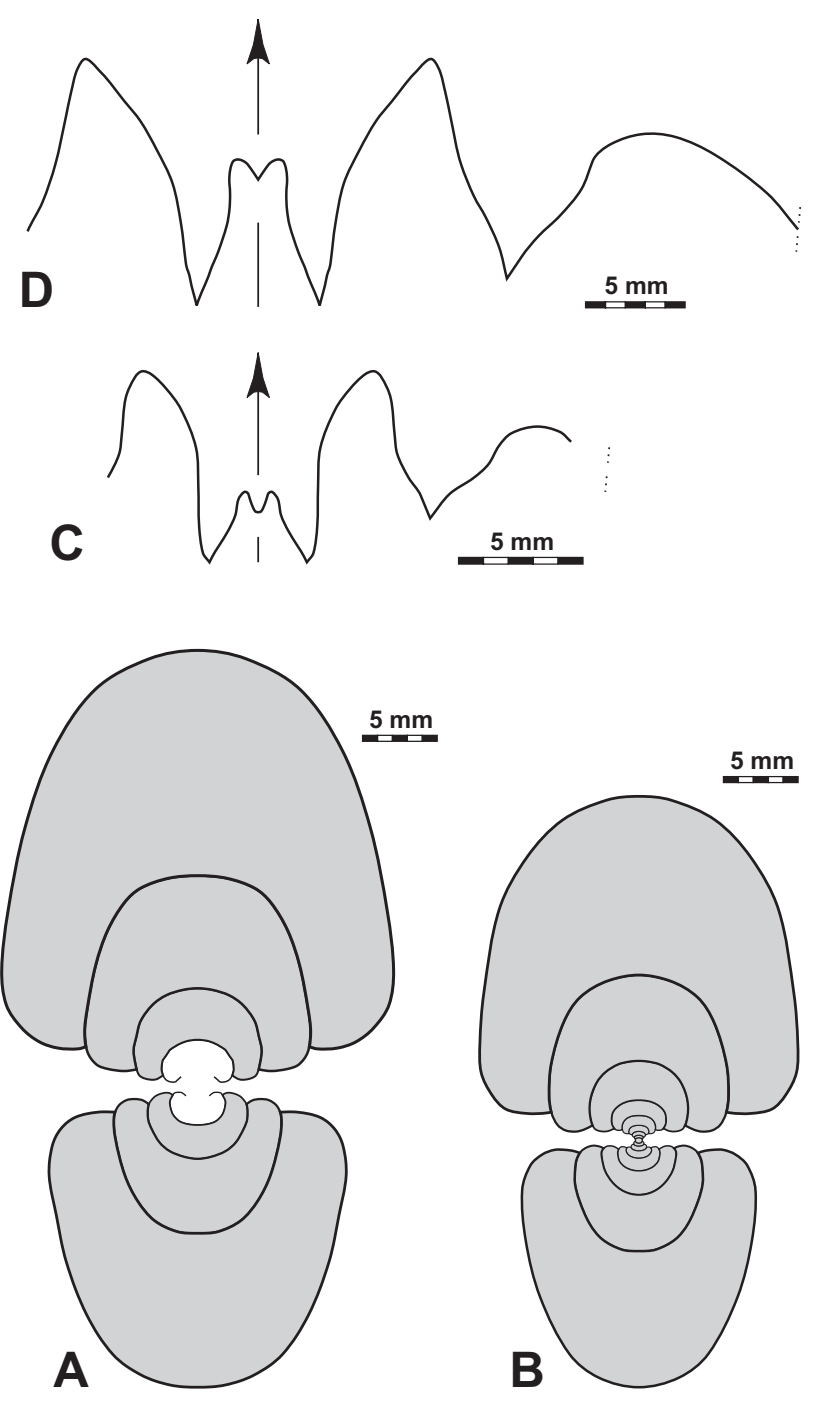

rounded ventrolateral saddle. The external lobe is much larger and deeper than the adventive lobe (Fig. 17C).

Discussion. More than 20 species of Sudeticeras are known so far, and many of them are insufficiently described or are based either on crushed material or on juvenile specimens (Moore 1950). This makes a comparison of the species difficult, and below, the two new species will be discussed in the frame of the better known species of the genus.

The suture line of Sudeticeras pusillobatum shows the best criteria to distinguish this species from all others. The narrowly rounded or even subacute ventrolateral saddle is not known from any other species, and the size of the external lobe, much deeper and wider than the adventive lobe, can only be seen in the other new species, S. occultornatum.

Sudeticeras pusillobatum differs from S. occultornatum in a number of characters: the shape of the conch is thickly discoidal in S. pusillobatum
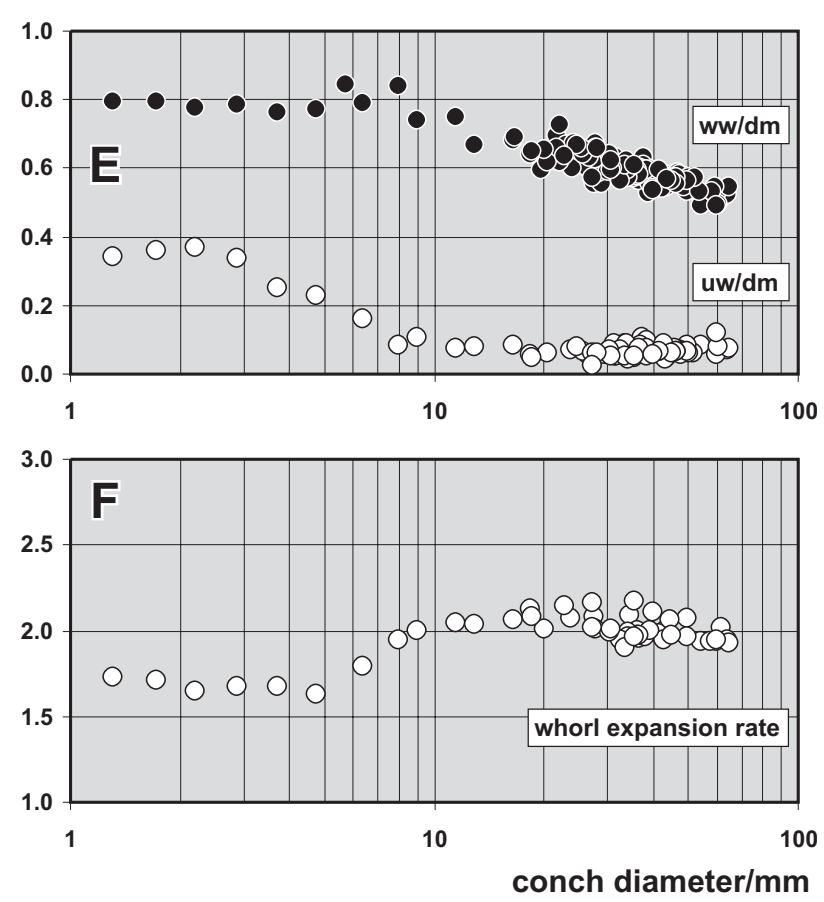

Fig. 17. Sudeticeras pusillobatum n. sp. from Horizon GI-4 of the Gara el Itima. A - Cross section, paratype MB.C.9053.1; $\times 1,5 ; \mathbf{B}$ - Cross section, paratype MB.C.9077.1; $\times 1,5 ; \mathbf{C}-$ Suture line, paratype MB.C.9077.7, at $17.4 \mathrm{~mm}$ ww, $12.0 \mathrm{~mm}$ wh; $\times 2.5$; D - Suture line, paratype MB.C.9077.6, at ca. $36 \mathrm{~mm} \mathrm{dm}, 22.5 \mathrm{~mm}$ ww, $23.5 \mathrm{~mm}$ wh; $\times 2$; E - Ontogenetic development of the whorl width index $(\mathrm{ww} / \mathrm{dm})$ and umbilical width index (uw/dm); F Ontogenetic development of the whorl expansion rate (WER).

$(\mathrm{ww} / \mathrm{dm}=0.55-0.60$ at $50 \mathrm{~mm} \mathrm{dm})$ and pachyconic in S. occultornatum (ww/dm 0.60-0.65 at $50 \mathrm{~mm} \mathrm{dm}$ ). The flanks of S. pusillobatum are less converging. The ornament of $S$. pusillobatum shows delicate crenulated growth lines, but the conch of S. occultornatum appears to be smooth in stages larger than $40 \mathrm{~mm} \mathrm{dm}$. The suture line shows the most conspicuous differences: The ventrolateral saddle is subangular in S.pusillobatum and broadly rounded in S. occultornatum. It is the shape of the ventrolateral saddle that distinguishes the new species from all known species of the genus.

\section{Sudeticeras occultornatum n. sp.}

Figs 18, 19

Derivation of name. After the Latin occultum $=$ to be hidden and the Latin ornatum = decorated, because of the lacking shell ornament.

Holotype. Specimen MB.C.9078.1 (coll. Ebbighausen and Korn 2004); figured here in Fig. 18E, F. 


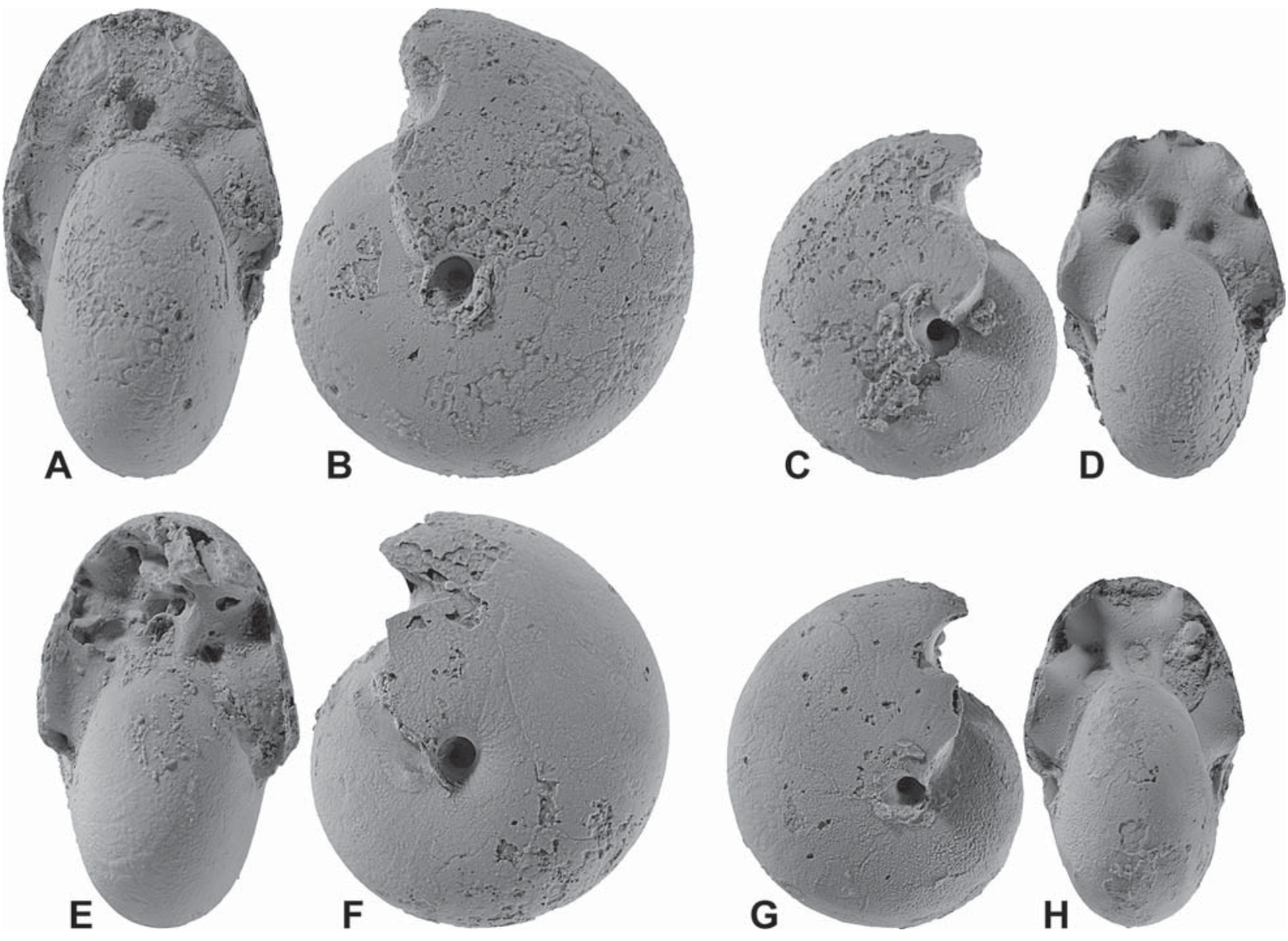

Fig. 18. Sudeticeras occultornatum n. sp. from Horizon GI-4 of the Gara el Itima; all $\times 1$. A, B - paratype MB.C.9078.8; C, D - paratype MB.C.9078.10; E, F - holotype MB.C.9078.1; G, H - paratype MB.C.9078.9.

Type locality and horizon. Gara el Itima, southeastern Anti-Atlas, Morocco; Horizon GI-4 (basal Hamou-Rhanem Formation), probably latest Viséan.

Material. 68 specimens between 18 and $78 \mathrm{~mm}$ conch diameter.

Diagnosis. Species of Sudeticeras with pachyconic conch at $20 \mathrm{~mm}$ diameter $(\mathrm{ww} / \mathrm{dm}=0.70-0.75)$ and thickly discoidal conch $(\mathrm{ww} / \mathrm{dm}=0.60-0.65)$ at $50 \mathrm{~mm}$ diameter. Flanks converging towards the venter; the conch is thickest near the umbilicus. Umbilicus wide in the juvenile stage, and very narrow in all stages larger than $10 \mathrm{~mm} \mathrm{dm}$ (uw/dm constantly between 0.05 and 0.12 ). Shell almost smooth. Suture line with wide external lobe ( 0.70 of the external lobe depth; 1.45 of adventive lobe), and high median saddle (more than 0.50 of the external lobe depth). Ventrolateral saddle rounded; adventive lobe shorter than the external lobe.

Description. A large number of more than 180 data sets of the conch measurements are available, and hence the morphometric spectrum of the species can be outlined (Fig. 19G, H). The intraspecific variability can best be studied in specimens between 20 and $70 \mathrm{~mm}$ conch diameter, because most of the specimens fall in this interval. A general ontogenetic trend is the continuous decrease of the ww/dm ratio; at $20 \mathrm{~mm}$ $\mathrm{dm}$ this lies between 0.70 and 0.75 , and at 60 to $70 \mathrm{~mm} \mathrm{dm}$ between 0.55 and 0.60 . The umbilical width and also the whorl expansion rate are not at all correlated with the ww/dm ratio. The umbilicus has, between 10 and $80 \mathrm{~mm}$ conch diameter, a constant width of 0.06 to 0.12 of the conch diameter, and the WER performs a slight increase from 1.75 at $10 \mathrm{~mm}$ to approximately 1.95 in the adult stage at $70 \mathrm{~mm} \mathrm{dm}$.

A number of specimens were sectioned, some of them figured in Fig. 19A-D. The cross section of specimen MB.C.9078.2 allows the study of all ontogenetic stages up to $68 \mathrm{~mm}$ conch diameter. The earliest whorls are widely umbilicate (uw/ $\mathrm{dm}=0.45$ at $3 \mathrm{~mm} \mathrm{dm}$ ), but the umbilicus becomes continuously smaller, with a uw/dm minimum of 0.04 at $20 \mathrm{~mm} \mathrm{dm}$. After this minimum, the umbilicus opens slightly in the adult conch. There occurs an almost continuous ontogenetic decrease of the ww/dm ratio. Only between 3 and $7 \mathrm{~mm} \mathrm{dm}$, this ratio is constant at 0.85 , but thereafter, it is reduced to 0.57 at $68 \mathrm{~mm} \mathrm{dm}$. Flanks and venter are broadly rounded throughout ontogeny, and the conch is widest at the rounded umbilical margin. Very similar conch cross sections can be seen in the paratypes MB.C.9078.3 and MB.C.9078.4. Cross sections MB.C.9078.5 and MB.C.9078.6 are very similar 


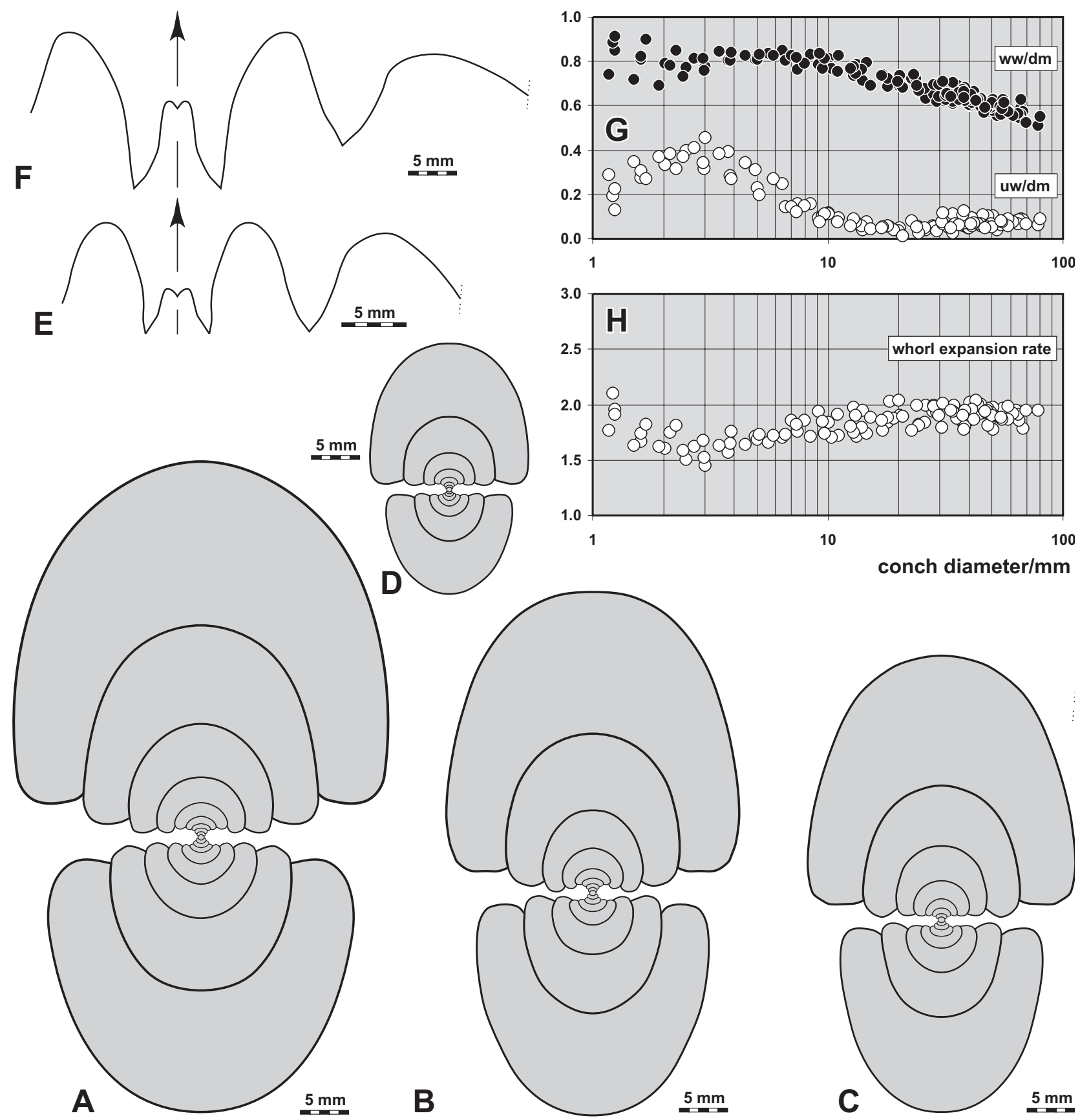

Fig. 19. Sudeticeras occultornatum n. sp. from Horizon GI-4 of the Gara el Itima. A - Cross section, paratype MB.C.9078.2; $\times 1,5 ; \mathbf{B}-$ Cross section, paratype MB.C.9078.13; $\times 1,5 ; \mathbf{C}-$ Cross section, paratype MB.C.9078.3; $\times 1,5 ; \mathbf{D}-$ Cross section, paratype MB.C.9078.4; × 1,5; E - Suture line, paratype MB.C.9078.12, at ca. $33 \mathrm{~mm} \mathrm{dm}, 21.8 \mathrm{~mm}$ ww, $19.4 \mathrm{~mm}$ wh; $\times 2 ; \mathbf{F}-$ Suture line, paratype MB.C.9078.14 (reversed), at $30.6 \mathrm{~mm}$ ww, $30.3 \mathrm{~mm}$ wh; $\times 1,5 ; \mathbf{G}$ - Ontogenetic development of the whorl width index (ww/dm) and umbilical width index (uw/dm); H - Ontogenetic development of the whorl expansion rate (WER).

in their ratios, but the inner whorls are not preserved in these specimens.

Paratype MB.C.9078.7 is the best preserved representative of the adult specimens. It has $66 \mathrm{~mm}$ conch diameter and belongs, with a ww/ $\mathrm{dm}$ ratio of 0.59 to the stouter variants of the species. As in most of the specimens, the shell surface suffered by aeolian erosion and is therefore difficult to interpret. Some spiral lines are visible on the venter in the dorsal portion of the conch, but otherwise, the shell is smooth except for some rhythmically strengthened growth line with biconvex course.

Specimen MB.C.9078.8 (Fig. 18A, B) has, at $58 \mathrm{~mm}$ diameter, a conch that is more compressed than specimen MB.C.9078.7. The shell is smooth except for some radial folds on the flank. Very similar are the specimens MB.C.9078.1 (the holotype), MB.C.9078.9, MB.C.9078.10, and MB.C.9078.11, representing the intermediate 
growth stage between 38 and $54 \mathrm{~mm}$ conch diameter (Fig. 18C-H).

The suture line of paratype MB.C.9078.12 $(33 \mathrm{~mm} \mathrm{dm})$ shows the characteristic features of the genus, i.e., a wide external lobe (width/ height ratio 0.67 at half depth) and a widely rounded ventrolateral saddle. The median saddle has 0.40 of the external lobe depth, and its prongs are lanceolate. The adventive lobe is almost symmetric and has slightly arched flanks (Fig. 19E). The larger paratype MB.C.9078.14 has, at approximately $50 \mathrm{~mm} \mathrm{dm}$, a similar suture line (Fig. 19F).

Discussion. For differences to Sudeticeras pusillobatum, see under that species. S. occultornatum resembles, in its conch dimensions, some of the older species of Sudeticeras, such as S. splendens (Bisat, 1928) and S. murracaoense Korn, 1997, but differs in the size of the external lobe that in S. occultornatum is much deeper than the adventive lobe.

Superfamily Goniatitoidea de Haan, 1825 Family Goniatitidae de Haan, 1825

\section{Goniatites de Haan, 1825}

Type species. Conchiliolithus Nautilites (sphaericus) Martin, 1809 [nomen nudum], = Ammonites sphaericus Sowerby, 1814 (Opinion 420 ICZN, 1956).

\section{Goniatites rodioni $\mathbf{n} . \mathbf{s p}$.}

Figs 20, 21, 22A

1941 Goniatites crenistria. - Delépine: 66, pl. 4: Fig. 2,3.

Derivation of name. After Rodion Ebbighausen (Köln), for his engagement in the field campaign in November, 2004.

Holotype. Specimen MB.C.9084.1 (coll. Ebbighausen and Korn 2004); figured here in Fig. 20A, B.

Type locality and horizon. Gara el Itima, southeastern Anti-Atlas, Morocco; Horizon GI-1 (Zrigat Formation), probably early part of the Late Viséan.

Material. 71 specimens between 30 and $70 \mathrm{~mm}$ conch diameter; half of which are fragments.

Diagnosis. Goniatites with globular to spindle-shaped conch at $20 \mathrm{~mm}$ diameter (ww/dm $0.90-1.10$ ), pachyconic to globular conch (ww/dm 0.70-0.90) at $40 \mathrm{~mm}$ diameter, and pachyconic conch (ww/dm $0.65-0.75)$ at $60 \mathrm{~mm}$ diameter. Umbilicus very narrow in all stages larger than $20 \mathrm{~mm} \mathrm{dm}$ (uw/dm 0.05-0.15). Ornamentation with crenulated biconvex and rursiradiate growth-lines with prominent dorsolateral projection. External sinus very shallow. Suture line with moderately narrow external lobe $(0.40-0.45$ of the external lobe
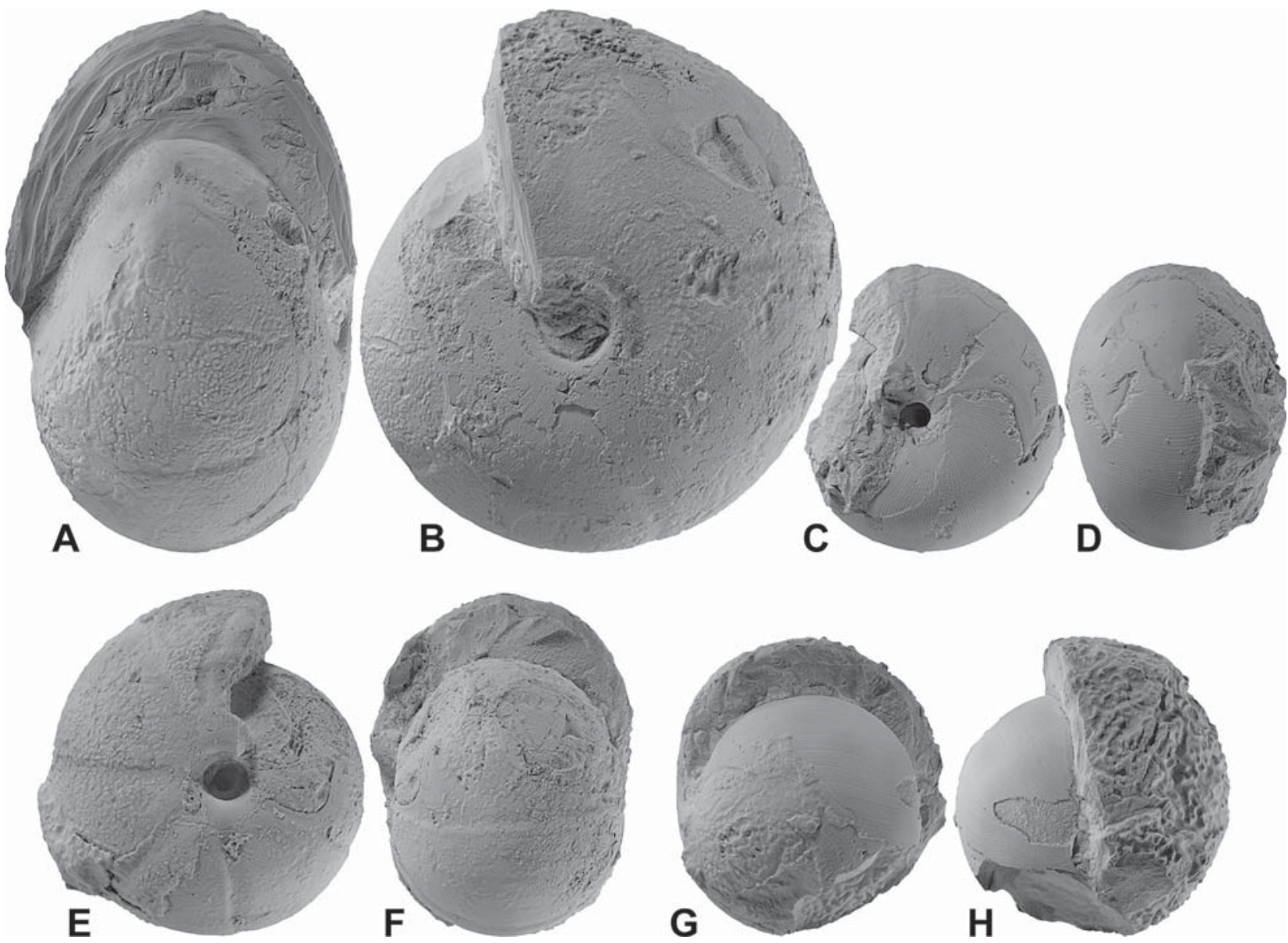

Fig. 20. Goniatites rodioni n. sp. from Horizon GI-1 of the Gara el Itima; all $\times 1$; A, B - holotype MB.C.9084.1; C, D paratype MB.C.9084.5; E, F - paratype MB.C.9084.8; G, H - paratype MB.C.9084.4. 

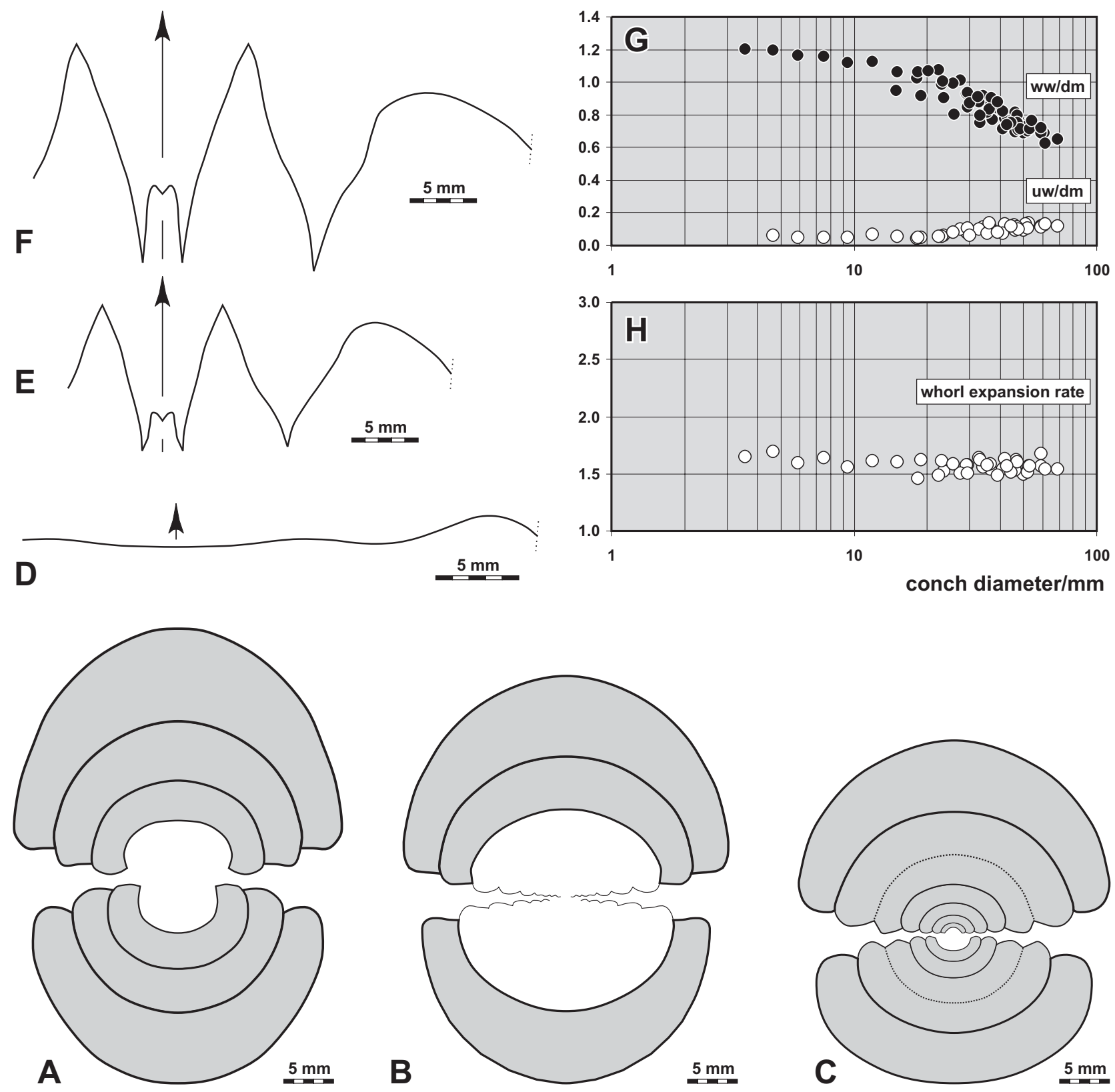

Fig. 21. Goniatites rodioni n. sp. from Horizon GI-1 of the Gara el Itima. A - Cross section, paratype MB.C.9084.3; $\times 1.5$; B - Cross section, paratype MB.C.9084.2; × 1.5; C - Cross section, paratype MB.C.9084.9; $\times 1.5$; D - Growth line course, paratype MB.C. 9084.4 , at $46.9 \mathrm{~mm} \mathrm{dm}, 30,8 \mathrm{~mm}$ ww, 20,2 mm wh; $\times 2.5 ; \mathbf{E}$ - Suture line, paratype MB.C.9084.6, at $24.5 \mathrm{~mm}$ ww, $16.0 \mathrm{~mm}$ wh; $\times 2 ; \mathbf{F}-$ Suture line (reversed), paratype MB.C.9084.7, at $28.9 \mathrm{~mm}$ ww, ca. $12.0 \mathrm{~mm}$ wh; $\times 2.5 ; \mathbf{G}-$ Ontogenetic development of the whorl width index (ww/dm) and umbilical width index (uw/dm); $\mathbf{H}$ - Ontogenetic development of the whorl expansion rate (WER).

depth), and low median saddle $(0.25-0.35$ of the external lobe depth).

Description. Most of the measured specimens range between 33 and $60 \mathrm{~mm}$ conch diameter, and thus it is the growth interval for which the intraspecific variability can be illustrated (Fig. 21G, H). Variability is normal for a Carboniferous goniatite species, and best expressed in the ww/dm ratio. There is also a strict ontogenetic trend observable; the conch becomes considerably thinner in the growth interval between 30 and $60 \mathrm{~mm}$ diameter. At $33 \mathrm{~mm} \mathrm{dm}$, the range of the ww/dm ratio ranges 0.80 to 0.91 , at $46 \mathrm{~mm}$ $\mathrm{dm}$ it is $0.70-0.82$, and at $60 \mathrm{~mm} \mathrm{dm}$ it is between 0.65 and 0.73 . Relative umbilical width and whorl expansion rate remain rather stable in the discussed interval, ranging from $0.10-0.15$ and 1.50-1.65, respectively.

None of the cross sections display the innermost whorls, which are completely recrystallized and destroyed. Therefore, ontogenetic stages smaller than $4 \mathrm{~mm}$ conch diameter are not known. The two cross sections MB.C.9084.2 and MB.C.9084.3 (Fig. 21B, A) represent the mor- 
phological range of the species, i.e., the more slender variants (paratype MB.C.9084.3: ww/ $\mathrm{dm}=0.92$ at $20 \mathrm{~mm} \mathrm{dm}$ ) and the stouter variants (paratype MB.C.9084.2: $\mathrm{ww} / \mathrm{dm}=1.05$ at $20 \mathrm{~mm}$ $\mathrm{dm})$. Both show cross sections with broadly rounded flanks and venter. The conch is widest in a short distance from the umbilicus, and the umbilical wall is steep.

Many specimens show remains of the shell ornament, but this is best preserved in the dorsal whorl portion of the globular paratype MB.C.9084.4 $(\mathrm{ww} / \mathrm{dm}=0.90)$. Here, at a conch diameter of approximately $30 \mathrm{~mm}$, there are fine, strongly crenulated growth lines preserved (Fig. 20G, H). They run slightly biconvex with a dorsolateral projection immediately near the umbilicus. Then follows a shallow lateral sinus, a very low and very wide ventrolateral saddle, and a barely visible ventral sinus. Specimen MB.C.9084.5 belongs to the more compressed forms (ww/ $\mathrm{dm}=0.82)$, and possesses a very similar ornament (Fig. 20C, D). The difference to specimen MB.C.9084.4 is that the dorsolateral projection of the growth lines is more pronounced and that the ventral sinus is slightly deeper (Fig. 21D).
All specimens possess steinkern constrictions. These are shallow and run almost straight across flanks and venter. Five or six such constrictions are present in specimens between 40 and $60 \mathrm{~mm}$ conch diameter. Constrictions are not present on the outer shell.

The suture line of the rather slender paratype MB.C.9084.6 has, at a whorl width of $24.5 \mathrm{~mm}$ (corresponding to a conch diameter of approximately $28 \mathrm{~mm}$ ), the characteristic outline of the genus Goniatites. The external lobe is $\mathrm{V}$-shaped with slightly curved flanks, and the median saddle is low ( 0.25 of the external lobe depth. At half of its depth, the width of the external lobe is less than 0.50 of its depth. The ventrolateral saddle is almost symmetric and pointed, and the adventive lobe is also almost symmetric with slightly sinuous flanks. The adventive lobe is wider than the external lobe (Fig. 21E).

The larger specimen MB.C.9084.7 belongs to the stout forms; this shows a suture line that is characterised by very narrow, deep lobes, and the external lobe has a width/height ratio of only 0.40 . The median saddle is higher than in specimen MB.C.9084.6, but still reaches only 0.35 of the external lobe depth (Fig. 21F).
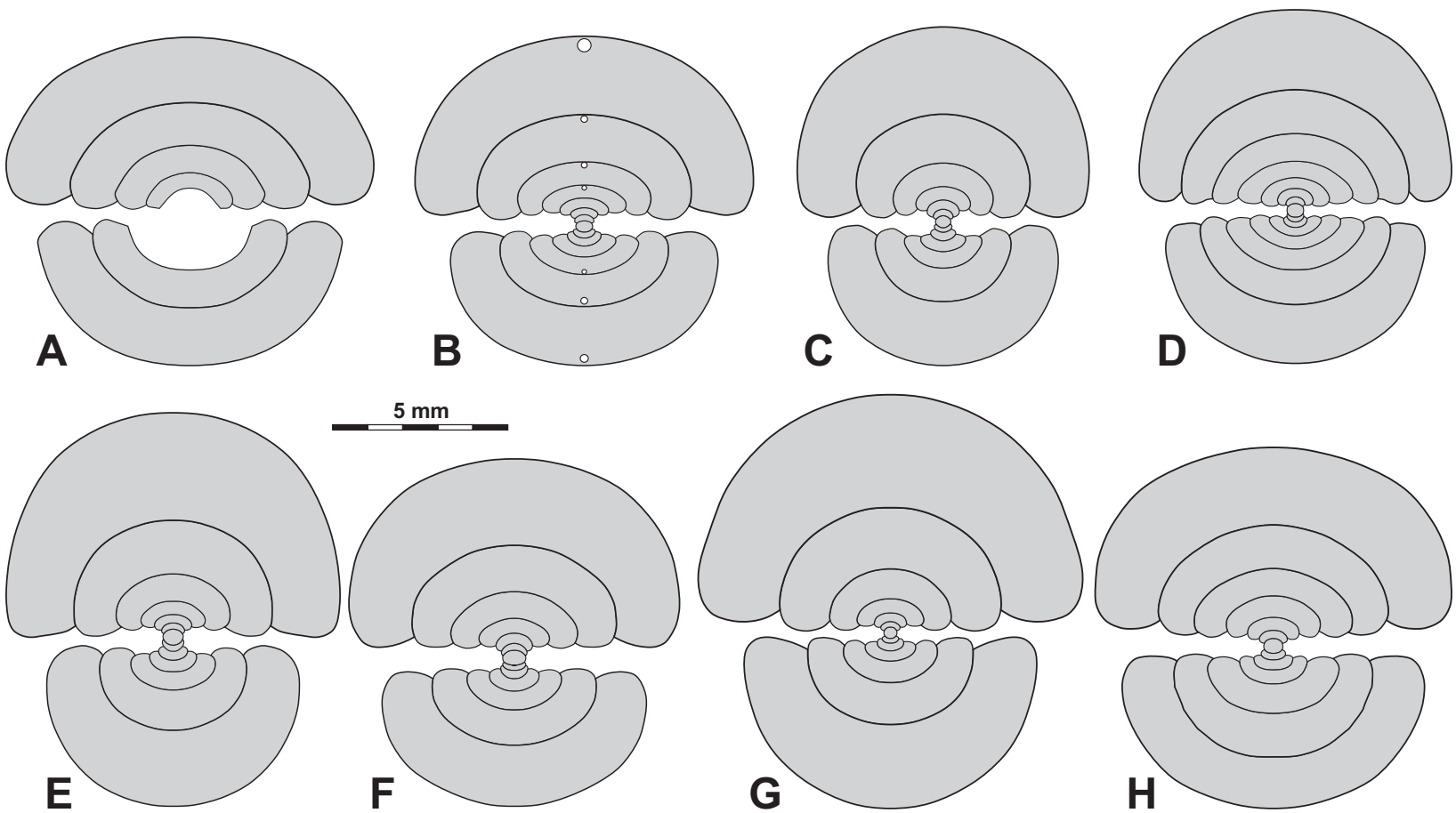

Fig. 22. Cross sections of the internal whorls of various species of Goniatites; all $\times 4$. A - Goniatites rodioni n. sp., Horizon GI-1, paratype MB.C.9084.9; B - Goniatites gerberi n. sp., Horizon GI-2, paratype MB.C.9088.2; C - Goniatites evelinae n. sp., Horizon GI-2, paratype MB.C.9058.2; D - Goniatites stenumbilicatus Kullmann, 1961, Aguasalio (Cantabrian Mountains), specimen IGT 1394-1970 (coll. Raćz); E - Goniatites multiliratus Gordon, 1962, Alhoso (Pontotoc Co., Oklahoma), specimen OUZC 5106 (coll. Mapes); F - Goniatites multiliratus Gordon, 1962, Alhoso (Pontotoc Co., Oklahoma), specimen OUZC 5108 (coll. Mapes); G - Goniatites hudsoni Bisat, 1934, Treak Cliff (Derbyshire), specimen Zx2229 (coll. Tilsley); H - Goniatites moorei Weyer, 1972, Dowel Farm (Derbyshire), specimen MB.C.2858.2 (coll. Weyer). [D after Kullmann \& Scheuch 1970; E, F after Korn et al. 2004; G, H after Korn \& Tilsley in press] 
Discussion. A comparison of Goniatites rodioni with the other species of the genus that lack spiral ornament is rather easy. G. fimbriatus (Foord \& Crick, 1897) has a similar conch, but differs in the much higher median saddle ( 0.45 of the external lobe depth) from G. rodioni (0.25). G. crenistria Phillips, 1836 has, unlike G. rodioni, growth lines that run with almost linear course across flanks and venter. In this respect, G. hudsoni Bisat, 1934 resembles G. rodio$n i$, but this species differs in the suture line: $G$. rodioni has a very narrow external lobe, narrower than the adventive lobe. Furthermore, the growth lines in G. rodioni show a much higher dorsolateral projection.

G. lazarus Korn et al., 2005 was also collected in the southeastern Anti-Atlas. It has a more slender conch shape, almost linear growth lines, and a narrowly rounded ventrolateral saddle. It can therefore easily be distinguished from the new species.

\section{Goniatites gerberi n. sp.}

Figs 22B, 23, 24

? 1941 Goniatites sphaericus. - Delépine: 67, pl. 4: Fig. 4,5.
1963a Goniatites (Goniatites) robustus. - Kullmann: 309, pl. 20: fig. 3 .

Derivation of name. After Wolfgang Gerber (Tübingen), to acknowledge his careful photography of the specimens for this work and many other preceding publications.

Holotype. Specimen MB.C.9088.1 (coll. Ebbighausen and Korn 2004); figured here in Fig. 23A-C.

Type locality and horizon. Gara el Itima, southeastern Anti-Atlas, Morocco; Horizon GI-2 (Zrigat Formation), probably early to middle part of the Late Viséan.

Material. 59 specimens between 20 and $70 \mathrm{~mm}$ conch diameter, of which approximately one third are fragments.

Diagnosis. Goniatites with thickly pachyconic conch at $10 \mathrm{~mm}$ diameter (ww/dm $0.80-0.85$ ), pachyconic conch (ww/ $\mathrm{dm} 0.70-0.80)$ at $30 \mathrm{~mm}$ diameter and thinly pachyconic conch (ww/dm $0.65-0.70)$ at $50 \mathrm{~mm}$ diameter. Umbilicus very narrow in all stages larger than $10 \mathrm{~mm} \mathrm{dm} \mathrm{(uw/dm}$ $0.10-0.16$ ), in the adult stage slightly opening; umbilical wall flat. Ornamentation with crenulated biconvex and slightly rursiradiate growth-lines with dorsolateral projection; external sinus shallow. 190 fine spiral lines. Suture line with V-
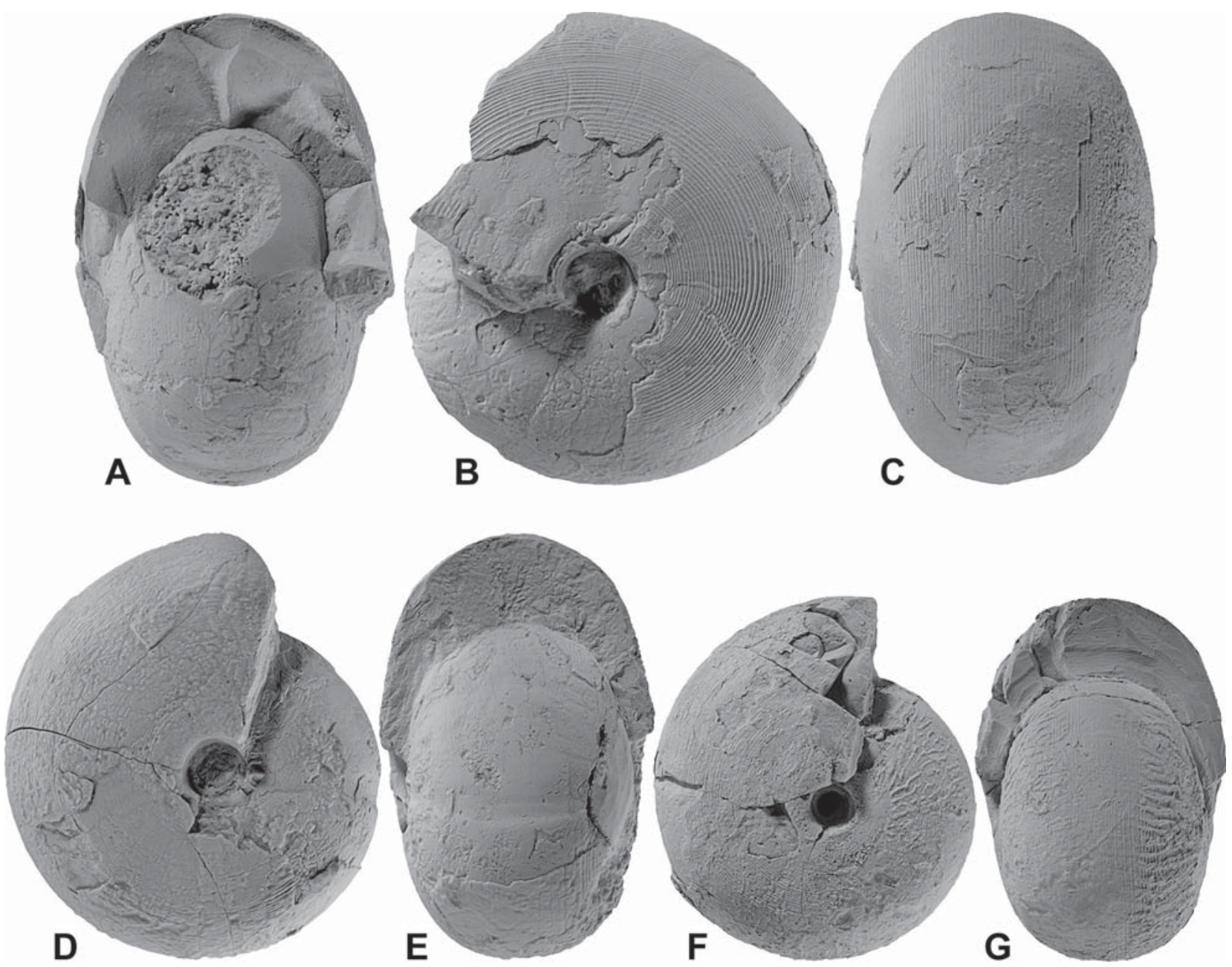

Fig. 23. Goniatites gerberi n. sp. from Horizon GI-2 of the Gara el Itima; all $\times 1$. A-C - holotype MB.C.9088.1; D, E paratype MB.C.9097.2; F, G - paratype MB.C.9097.1. 
shaped, moderately narrow external lobe $(0.50$ of the external lobe depth), and low median saddle ( 0.35 of the external lobe depth).

Description. In the bivariate plots of the morphometric data, the ontogenetic changes and the variability is expressed; ontogenetic trends are described below. The intraspecific variability is normal for a Goniatites species, with more slender and stouter forms, of which the latter show more depressed whorls with low aperture (Fig. 24G, H).

The cross section of paratype MB.C.9088.2 displays the conch development from the initial stage to a maximum diameter of almost $60 \mathrm{~mm}$ (Figs 22B, 24A). Ten and a half whorls are preserved and demonstrate rather significant ontogenetic changes. In the early juvenile stage, at $1 \mathrm{~mm} \mathrm{dm}$, there is a rather widely umbilicate, globular conch $\quad(u w / d m=0.35 ; \quad w w / d m=0.88)$. The uw/dm ratio becomes continuously lower, and already at $5.5 \mathrm{~mm} \mathrm{dm}$, it has a value of only 0.06 . There is a slight heightening in the late ontogeny, and in the last whorl at $58 \mathrm{~mm} \mathrm{dm}$, it has 0.12 . The conch is thickest at $2.5 \mathrm{~mm} \mathrm{dm}$, where it is spindle-shaped (ww/dm 1.22). A subsequent
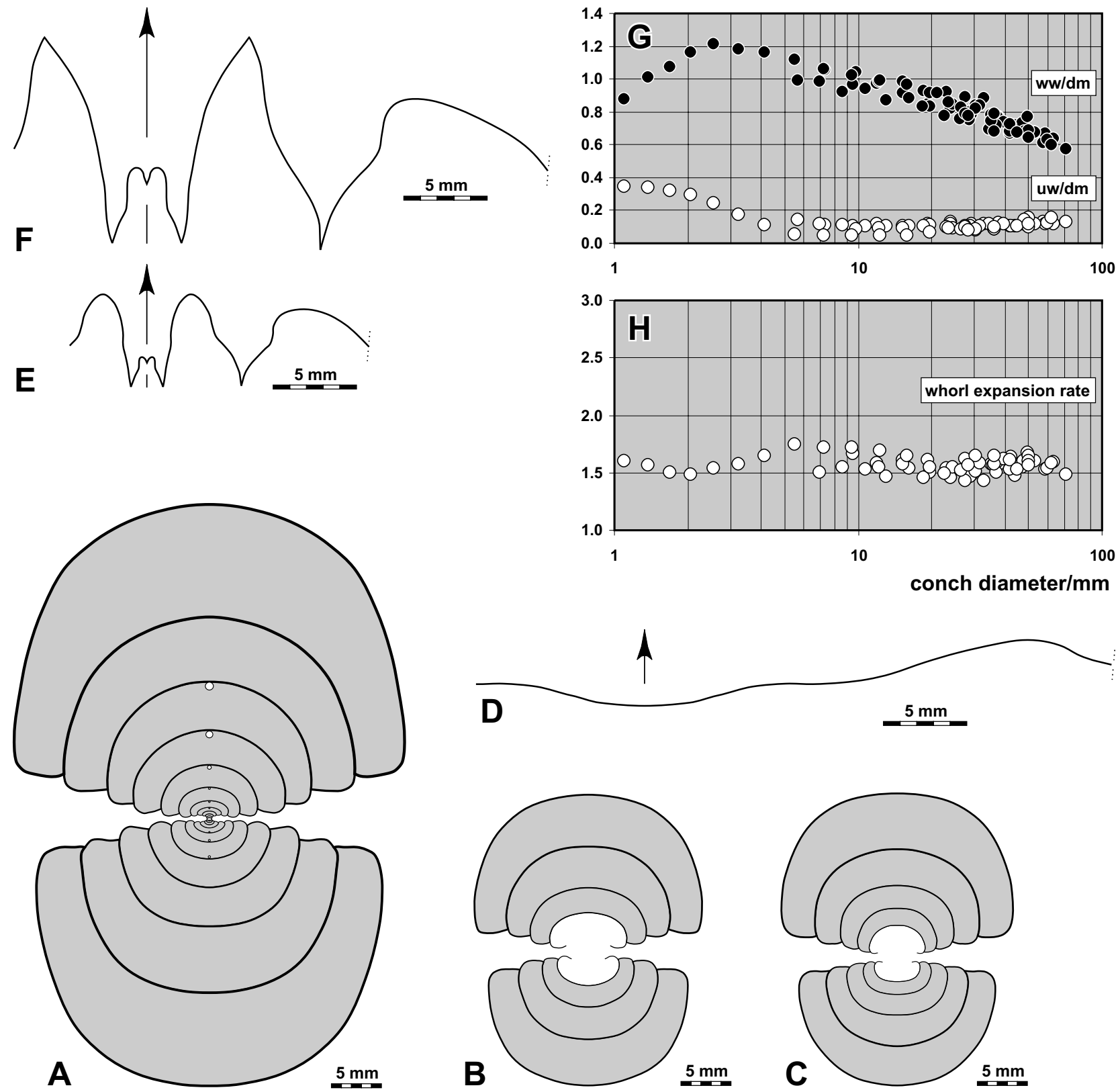

Fig. 24. Goniatites gerberi n. sp. from Horizon GI-2 of the Gara el Itima. A - Cross section, paratype MB.C.9088.2; $\times 1.5$; $\mathbf{B}$ - Cross section, paratype MB.C.9088.6; $\times 1.5 ; \mathbf{C}$ - Cross section, paratype MB.C.9088.7; $\times 1.5$; D - Growth line course, paratype MB.C. 9088.3 , at $46.9 \mathrm{~mm} \mathrm{dm}, 30,8 \mathrm{~mm}$ ww, $20,2 \mathrm{~mm}$ wh; $\times 2.5 ; \mathbf{E}-$ Suture line, paratype MB.C.9088.5, at $17.1 \mathrm{~mm}$ ww, $8.6 \mathrm{~mm}$ wh; $\times 2.5 ; \mathbf{F}-$ Suture line (reversed), paratype MB.C.9088.4, at $24.9 \mathrm{~mm}$ ww, $15.5 \mathrm{~mm}$ wh; $\times 2.5$; G - Ontogenetic development of the whorl width index (ww/dm) and umbilical width index (uw/dm); H - Ontogenetic development of the whorl expansion rate (WER). 
linear decrease can be seen, and the conch is pachyconic $(w w / d m=0.67)$ at $58 \mathrm{~mm} \mathrm{dm}$. The whorl expansion rate ranges between 1.50 and 1.60 throughout ontogeny, but there is a heightening to a maximum of $1.70-1.75$ between 5 and $12 \mathrm{~mm} \mathrm{dm}$. All stages show a widely rounded venter and slightly converging, rounded flanks; the conch is widest near the umbilicus. The umbilical margin is rounded, and the umbilical wall is rounded in juvenile stages and flattened in stages larger than $18 \mathrm{~mm} \mathrm{dm}$.

Specimens of all preserved growth stages possess a delicate ornament in which spiral lines are predominant. The largest well preserved specimen, the holotype MB.C. 9088.1 has, at $63 \mathrm{~mm}$ conch diameter, approximately 190 spiral lines on flanks and venter (Fig. 23A-C). These spirals are irregularly spaced in distances of $0.3-0.8 \mathrm{~mm}$. They are coarser than the growth lines of which $8-10$ can be counted in an interval of $1 \mathrm{~mm}$. The course of the growth lines is biconvex with a wellvisible dorsolateral projection and a shallow and wide ventral sinus. A granulation of the spiral lines is visible at the crossings with the growth lines. The steinkern has shallow constrictions that follow the course of the growth lines; they are strongest on flanks and venter.

The smaller specimens MB.C.9088.3 and MB.C. 9097.1 show, both at $40-50 \mathrm{~mm} \mathrm{dm}$, the same ornament with irregularly spaced spiral lines and slightly biconvex growth lines that show a rather prominent dorsolateral projection (Figs 23F, G, 24D). Both specimens display the conspicuous Runzelschicht pattern in the dorsal portion of the conch, but this is restricted to the flanks where it occurs symmetrically. It is composed of rough elongate radial wrinkles, arranged $1.2 \mathrm{~mm}$ apart, and coccasionally bifurcate in ventral direction. They disappear suddenly towards the venter.

The suture line of paratype MB.C.9088.4 has, at $25 \mathrm{~mm}$ whorl width (corresponding to appr. 30-35 mm dm) a $\mathrm{V}$-shaped, moderately narrow external lobe ( 0.50 of the lobe depth) with concavely curved flanks. The median saddle has a height of 0.36 of the external lobe depth. On the flank follow an asymmetric, acute ventrolateral saddle and an adventive lobe that is as wide as the external lobe. It possesses slightly curved flanks, with the dorsal flank more sinuous than the ventral (Fig. 24F).

In the juvenile paratype MB.C.9088.5 is the external lobe slightly pouched, and the ventrolateral saddle is narrowly rounded. The adventive lobe is symmetric (Fig. 24E).
Discussion. Comparable species of Goniatites are G. stenumbilicatus Kullmann, 1961, G. moorei Weyer, 1972, G. multiliratus Gordon, 1962, G. spirifer Roemer, 1850, G. olysia Korn, 2002, and G. evelinae n. sp.; all show a stout conch and a shell surface fully covered by fine spiral lines. The difference of the new species to the listed are as follows: G. stenumbilicatus possesses a wider spindle-shaped early juvenile stage $(2.5 \mathrm{~mm} \mathrm{dm})$ and a much less developed evolute early juvenile stage. G. moorei has also a globular or even spindle-shaped early juvenile stage. G. multiliratus has a similar conch development, but differs in the higher number of spirals (200) and the faster expanding whorls (WER $>1.80$ in specimens larger than $10 \mathrm{~mm} \mathrm{dm}$ ). G. spirifer has a stronger radial ornament in middle and adult stages and a higher median saddle in the suture line. G. olysia has a conch morphology that is similar in all growth stages. G. evelinae has a strongly sinuous cross section of the umbilical wall.

\section{Goniatites evelinae n. sp.}

Figs 22C, 25, 26

Derivation of name. After Evelin Stenzel (Museum für Naturkunde, Berlin), to acknowledge her careful preparation of the specimens.

Holotype. Specimen MB.C.9058.1 (coll. Ebbighausen 2003); figured here in Fig. 25A, B.

Type locality and horizon. Gara el Itima, southeastern Anti-Atlas, Morocco; Horizon GI-2 (Zrigat Formation), probably early to middle part of the Late Viséan.

Material. 16 specimens between 30 and $55 \mathrm{~mm}$ conch diameter.

Diagnosis. Goniatites with globular conch between 2 and $10 \mathrm{~mm}$ diameter (ww/dm 0.90-1.00), pachyconic conch (ww/ $\mathrm{dm} 0.70-0.80)$ at $30 \mathrm{~mm}$ diameter and thinly pachyconic conch (ww/dm $0.65-0.70)$ at $50 \mathrm{~mm}$ diameter. Umbilicus very narrow in all stages larger than $7 \mathrm{~mm} \mathrm{dm}$ (uw/dm 0.02-0.10), in the adult stage slightly opening. Umbilical wall strongly incurved in cross section. Ornamentation with crenulated, slightly biconvex and rectiradiate growth-lines; external sinus shallow. 160 fine spiral lines. Suture line with moderately narrow external lobe ( 0.45 of the external lobe depth), and low median saddle ( 0.35 of the external lobe depth).

Description. The bivariate plots (Fig. 26E, F) of the three conch parameters whorl width index, umbilical width index, and whorl expansion rate display the ontogenetic trends in the investigated specimens and the relatively low intraspecific variability.

Two cross sections were produced from paratypes MB.C.9058.2 and MB.C.9069.1 (Figs 22C, 26A, B). Both show similar ontogenetic trends of conch development with a widely umbilicate early juvenile stage, a globular late juvenile 


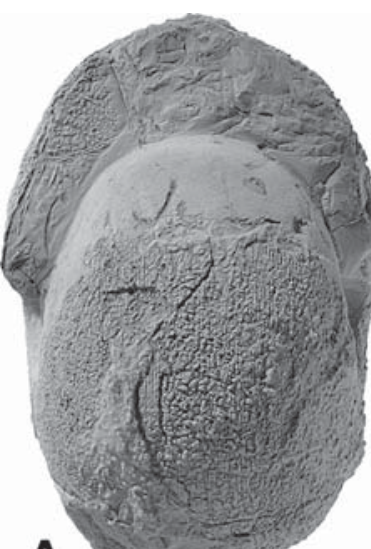

A

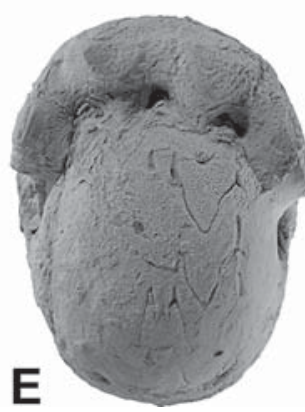

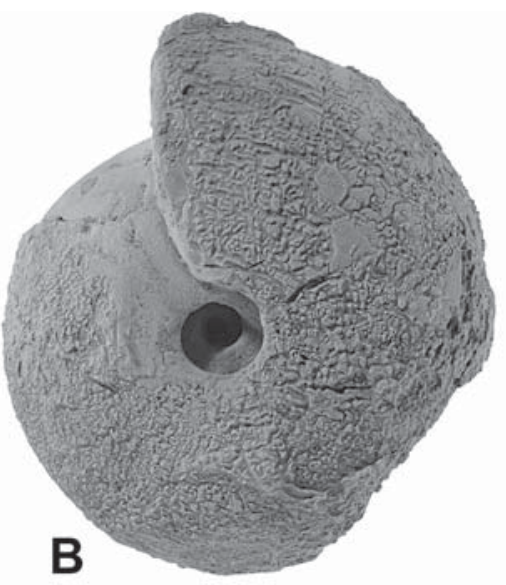

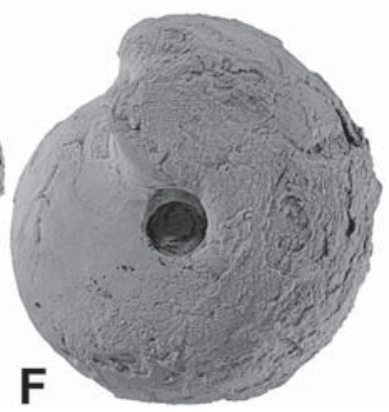

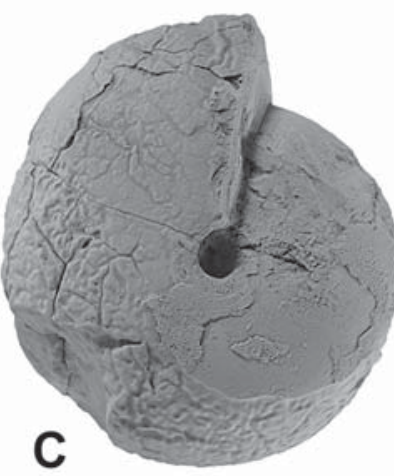

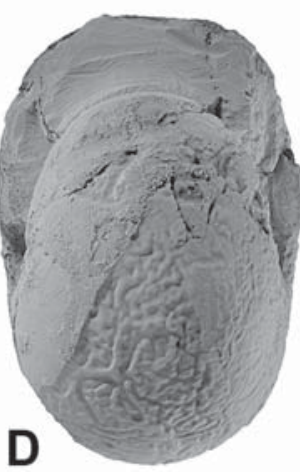

G

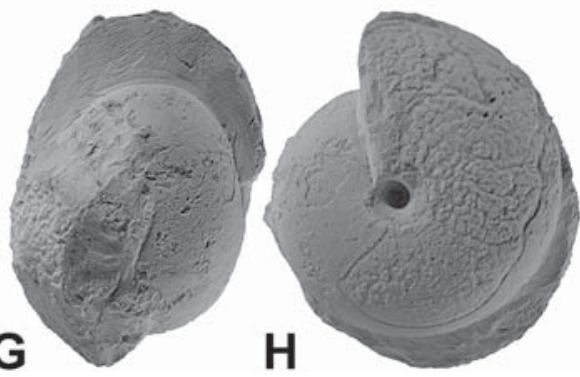

Fig. 25. Goniatites evelinae n. sp. from Horizon GI-2 of the Gara el Itima; all $\times 1$. A, B - holotype MB.C.9058.1; C, D paratype MB.C.9037.2; E, F - paratype MB.C.9069.2; G, H - paratype MB.C.9037.1.
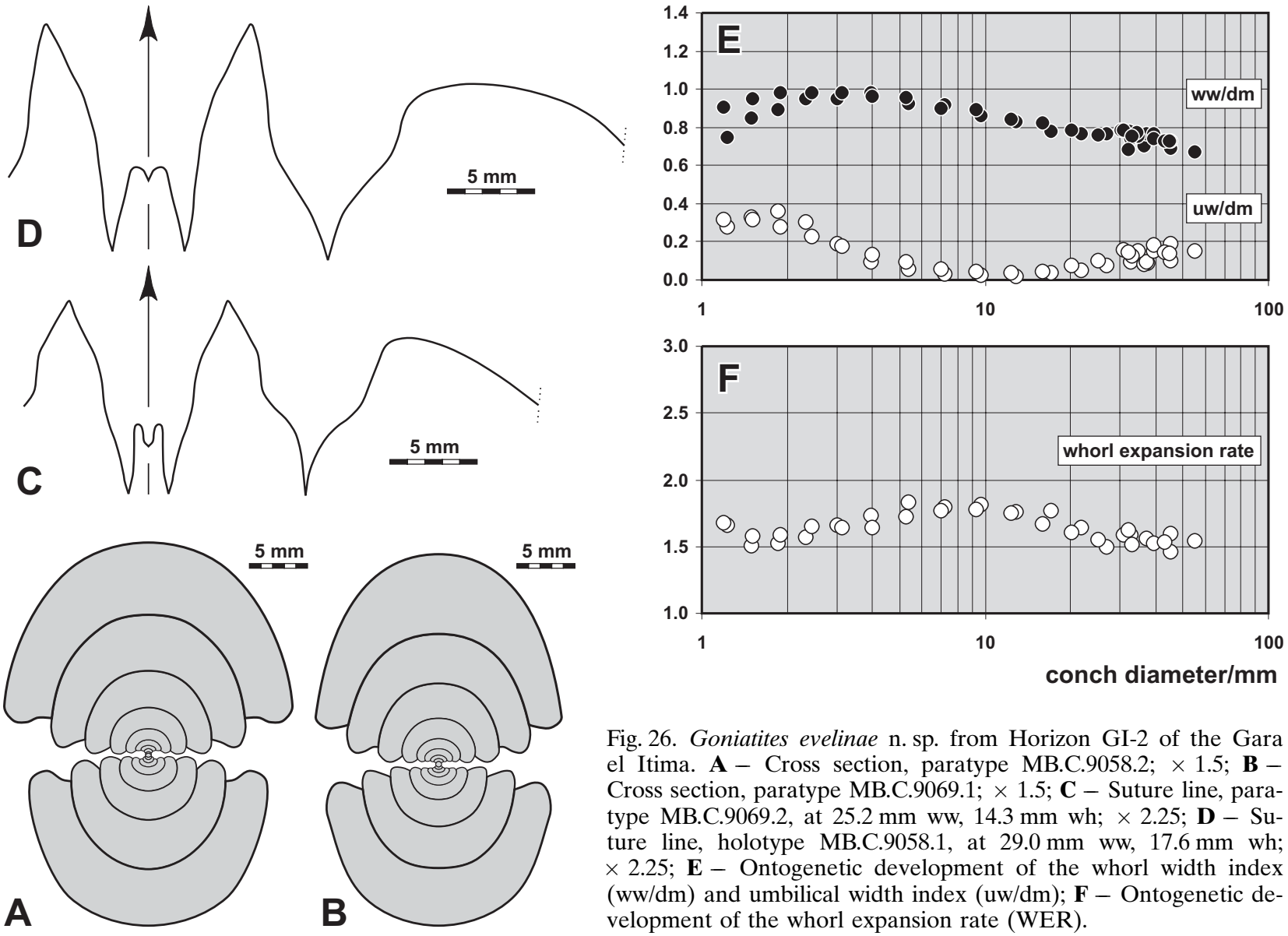

Fig. 26. Goniatites evelinae n. sp. from Horizon GI-2 of the Gara el Itima. A - Cross section, paratype MB.C.9058.2; $\times 1.5 ; \mathbf{B}-$ Cross section, paratype MB.C.9069.1; × 1.5; C - Suture line, paratype MB.C.9069.2, at $25.2 \mathrm{~mm}$ ww, $14.3 \mathrm{~mm}$ wh; $\times 2.25$; D $-\mathrm{Su}-$ ture line, holotype MB.C. 9058.1 , at $29.0 \mathrm{~mm}$ ww, $17.6 \mathrm{~mm}$ wh; $\times 2.25 ; \mathbf{E}-$ Ontogenetic development of the whorl width index (ww/dm) and umbilical width index (uw/dm); F - Ontogenetic development of the whorl expansion rate (WER). 
stage, and a pachyconic and involute adult stage. Specimen MB.C.9058.2 has the maximum uw/dm ratio of almost 0.40 at $2 \mathrm{~mm}$ conch diameter; thereafter this value is rapidly lowered toward almost 0.00 at $10 \mathrm{~mm} \mathrm{dm}$. In later stages, the umbilicus opens to $u w / d m=0.13$ at $33 \mathrm{~mm} \mathrm{dm}$. The conch is thickest at $4 \mathrm{~mm} \mathrm{dm}$, where a maximum ww/dm ratio of almost 1.00 is attained; the conch becomes slimmer in later stages but has still 0.75 at $33 \mathrm{~mm} \mathrm{dm}$. The development of the whorl expansion rate runs almost diametrically to the umbilical width; there is an increase from 1.50 to more than 1.80 between 1.5 and $5.5 \mathrm{~mm} \mathrm{dm}$ and a subsequent slight decrease. Both specimens show whorl cross sections that are widest at the umbilical margin, with strongly converging flanks. The characteristic feature of the sinuous, incurved umbilical wall can be seen in stages over $10 \mathrm{~mm} \mathrm{dm}$ and is best visible in the adult stage.

Paratype MB.C.9037.1 displays the ornament in a growth stage of approximately $22 \mathrm{~mm} \mathrm{dm}$. The spiral lines are fine, and not much more prominent than the crenulated growth lines (Fig. 25G, H).

The suture line is characteristic for the genus Goniatites. Holotype MB.C.9058.1 shows, at approximately $43 \mathrm{~mm} \mathrm{dm}$, a narrow, Y-shaped external lobe with flanks that diverge particularly in the upper half of the lobe (Fig. 26D). The width/height ratio of the external lobe is 0.46 , and the median saddle has 0.37 of the external lobe depth. On the flank follow a narrow, asymmetric and dorsally inclined, pointed ventrolateral saddle and an asymmetric adventive lobe with rather strongly curved flanks. The adventive lobe is wider than the external lobe.

Some characteristic features can be seen in the suture line of the smaller paratype MB.C.9069.2 (dm appr. $35 \mathrm{~mm}$ ). The external lobe is almost V-shaped; it has sinuous flanks. The width of this lobe is 0.47 of the depth, and the median saddle reaches 0.36 of the external lobe depth. The ventrolateral saddle has a tectiform outline and the adventive lobe is asymmetric (Fig. 26C).

Discussion. Goniatites evelinae n. sp. differs from the co-occurring species G. stenumbilicatus Kullmann, 1961 and G. gerberi by the sinuous cross section of the umbilical wall, which is also the separating criterion from all other species of Goniatites.

\section{Goniatites stenumbilicatus Kullmann, 1961}

Figs 22D, 27, 28

1961 Goniatites (Goniatites) stenumbilicatus stenumbilicatus Kullmann: 290, pl. 21: figs 2-5, textfig. 9a-c, 10c-d.

1961 Goniatites (Goniatites) stenumbilicatus globiformis Kullmann: 294, pl. 22: fig. 4a, b.

1963b Goniatites (Goniatites) stenumbilicatus stenumbilicatus. - Kullmann: 188, pl. 5: figs 4, 5.

1963 boniatites (Goniatites) stenumbilicatus globiformis. Kullmann: 188, pl. 5: fig. 6.

1970 Goniatites stenumbilicatus. - Kullmann \& Scheuch: 408, textfig. 7 .

Holotype. Specimen IGT 1160/388 (coll. Kullmann); figured by Kullmann (1961) on pl. 21: fig. 3 .

Type locality and horizon. Peña Roscas, León Province, Spain; Alba Formation, probably early to middle part of the Late Viséan.

Material. Three specimens between 38 and $66 \mathrm{~mm}$ conch diameter.
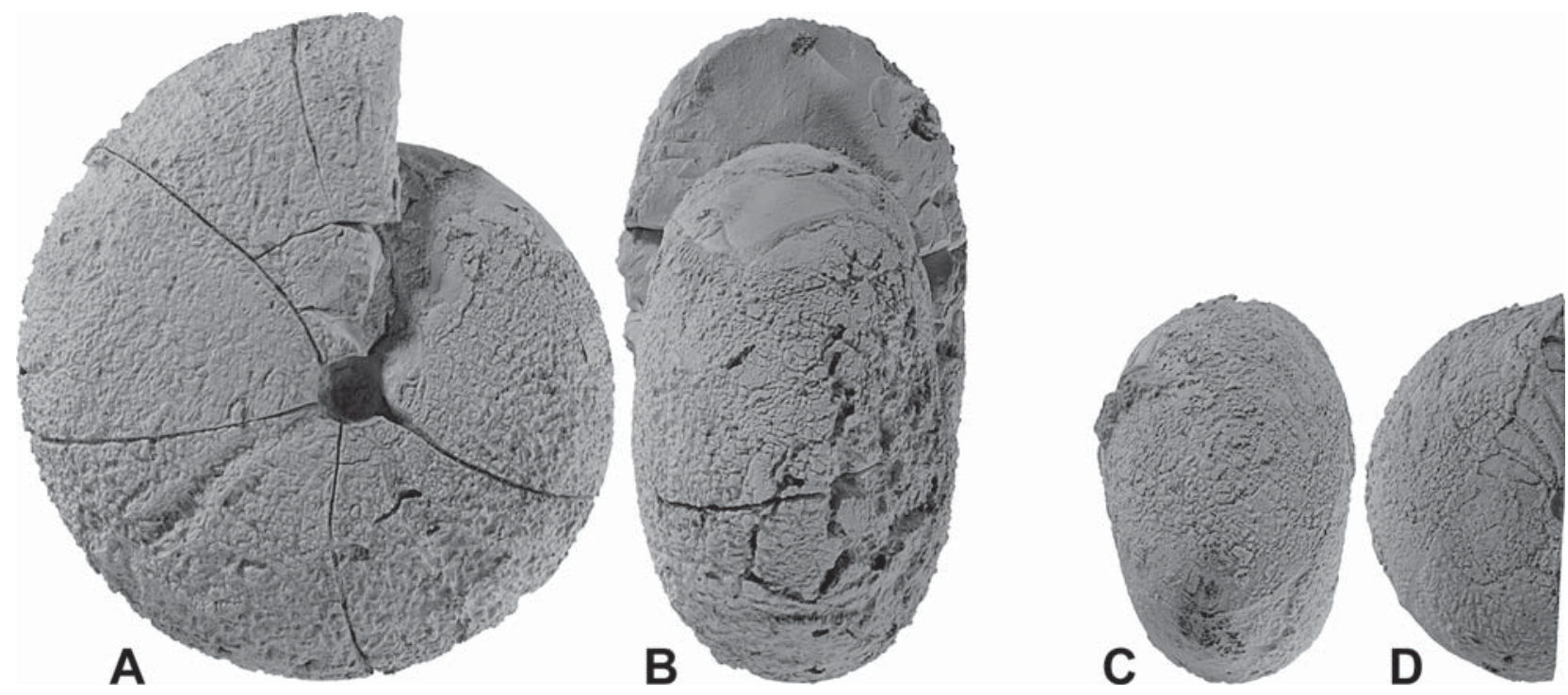

Fig. 27. Goniatites stenumbilicatus Kullmann, 1961 from Horizon GI-2 of the Gara el Itima; all $\times 1$. A, B - specimen MB.C.9070; C, D - specimen MB.C.9060. 
Diagnosis. Goniatites with spindle-shaped conch in early growth stages $(w w / d m>1.30$ at $2.5 \mathrm{~mm} \mathrm{dm})$, globular conch at $10 \mathrm{~mm}$ diameter (ww/dm 0.90-1.05), and pachyconic conch (ww/dm $0.65-0.75)$ at $30 \mathrm{~mm}$ diameter. Umbilicus very narrow in all stages larger than $4 \mathrm{~mm} \mathrm{dm}(\mathrm{uw} / \mathrm{dm}<0.10)$. Umbilical wall rounded, umbilical wall flat. Ornamentation with crenulated, slightly biconvex and rectiradiate growthlines; external sinus shallow. 180 fine spiral lines. Suture line with moderately narrow external lobe $(0.50$ of the external lobe depth), and moderate median saddle ( 0.50 of the external lobe depth).

Description. The cross section of specimen MB.C.9060 allows the observation of ontogenetic trends between 2.2 and $38 \mathrm{~mm}$ conch diameter (Fig. 28A). The conch is involute in all stages, with an uw/dm ratio of constantly $0.06-0.10$. A similarly low variability can be seen in the aperture height; the whorl expansion rate ranges, with a minor ontogenetic trend towards higher values, between 1.48 and 1.65 . Only the relative thickness of the whorls perform striking changes. In the ontogenetic interval between 2.2 and $38 \mathrm{~mm}$ conch diameter, there is a continuous and linear decrease of the ww/dm ratio, from 1.36 to 0.68. All stages show sections with broadly rounded, converging flanks and an also broadly rounded venter.

The largest specimen MB.C.9070 has a thickly discoidal conch $(\mathrm{ww} / \mathrm{dm}=0.54)$ with very narrow
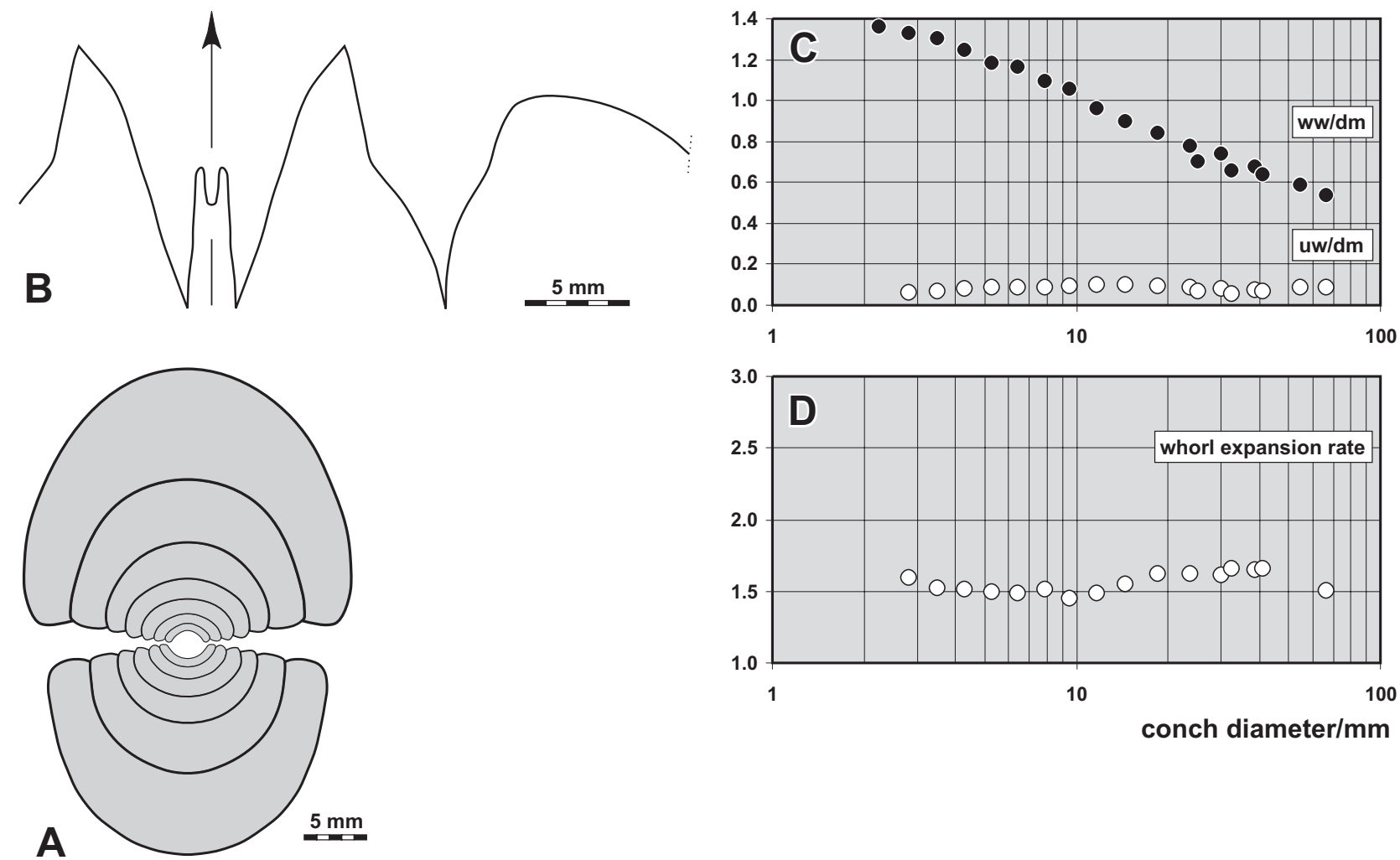

Fig. 28. Goniatites stenumbilicatus Kullmann, 1961 from Horizon GI-2 of the Gara el Itima. A - Cross section, specimen MB.C. $9060 ; \times 1.5 ; \mathbf{B}-$ Suture line, specimen MB.C. 9060 , at ca. $36 \mathrm{~mm} \mathrm{dm}, 24.9 \mathrm{~mm}$ ww, $19.6 \mathrm{~mm}$ wh; $\times 2.5$; C - Ontogenetic development of the whorl width index (ww/dm) and umbilical width index (uw/dm); D - Ontogenetic development of the whorl expansion rate (WER). delicate spiral lines and sinuous steinkern constrictions (Fig. 27A, B).

The suture line of specimen MB.C.9060 (ca. $36 \mathrm{~mm} \mathrm{dm}$ ) is characteristic for its narrow, Vshaped external lobe with strongly diverging, almost straight flanks, and a width/depth ratio being 0.50 . The median saddle is very narrow and is little more than half as high as the external lobe depth. An acute ventrolateral saddle and a slightly asymmetric adventive lobe with sinuous flanks complete the external suture line (Fig. 28B).

D iscussion. G. stenumbilicatus Kullmann, 1961 is characteristic for its remarkable ontogenetic changes of the conch morphology, with extremely wide inner whorls that lead to a spindleshaped conch (Fig. 22D), but with rather slender adult whorls. This is particularly a criterion to separate this species from other spirally-ornamented species of Goniatites, e.g. G. moorei Weyer, 1971, G. multiliratus Gordon, 1962, G. spirifer Roemer, 1850, G. olysia Korn, 2002, G. gerberi n. sp., and G. evelinae n. sp. In all these species, the inner whorls are less wide, but the adult 
stage is stouter. A further character that distinguishes G. stenumbilicatus from the others is the high median saddle (more than 0.50 of the external lobe depth), and the very narrow base of the external lobe.

\section{Hypergoniatites Ruzhencev \& Bogoslovskaya, 1970}

Type species. Hypergoniatites exiguus Ruzhencev \& Bogoslovskaya, 1970

\section{Hypergoniatites fusiger $\mathbf{n} . \mathbf{s p}$.}

Figs 29, 30, 31A

Derivation of name. After Latin fusus $=$ spindle and gerere $=$ to bear, because of the spindle-shaped inner whorls.

Holotype. Specimen MB.C.9081.1 (coll. Ebbighausen and Korn 2004); figured here in Fig. 29A, B.

Type locality and horizon. Gara el Itima, southeastern Anti-Atlas, Morocco; Horizon GI-4 (basal Hamou-Rhanem Formation), probably latest Viséan.

Material. 8 specimens between 13 and $62 \mathrm{~mm}$ conch diameter.

Diagnosis. Species of Hypergoniatites with spindle-shaped conch at $2 \mathrm{~mm}$ diameter $(\mathrm{ww} / \mathrm{dm}=1.35-1.40)$, pachyconic conch (ww/dm 0.70$)$ at $20 \mathrm{~mm}$ diameter, and thickly discoidal conch $(w w / d m ~ 0.50)$ at $50 \mathrm{~mm}$ diameter. Umbilicus very narrow in all stages larger than $3 \mathrm{~mm} \mathrm{dm}$ (uw/dm $0.05-0.10$ ). Ornamentation with biconvex and slightly prorsiradiate growth-lines and 130 fine spiral lines. Suture line with rather narrow external lobe ( 0.55 of the external lobe depth), and low median saddle ( 0.40 of the external lobe depth).

Description. The three cross sections MB.C.9081.2, MB.C.9081.3, and MB.C.9081.4 as well as the additional specimens show an astonishing little variability, when the conch shape is regarded (Fig. 30A-C). All data points of the conch width index (whorl width/conch diameter) follow a strict ontogenetic trajectory, and also the umbilical width index varies within narrow limits. The bivariate plot demonstrates the striking ontogenetic changes in the whorl width; the conch is spindle-shaped at $2 \mathrm{~mm}$ conch diameter $(w w / d m=1.35-1.40 ;$ Fig. $31 \mathrm{~A})$, and thereafter, this ratio decreases almost continuously to less than 0.50 at $50 \mathrm{~mm} \mathrm{dm}$. Only the early juvenile stage has an open umbilicus; already at $7 \mathrm{~mm}$ $\mathrm{dm}$ there is a uw/dm ratio of less than 0.10 . Such a value is maintained throughout ontogeny. A character that is more variable is the whorl expansion rate, which differs in the various specimens. An ontogenetic trend towards higher aperture is observable; a WER value of more than 2.00 is exceeded by adult conchs. All stages show widely rounded flanks and venter, and the conch is usually thickest in some distance from the umbilicus. The umbilical wall is steep in juveniles and preadult stages, but oblique in adult whorls (Fig. 30E, F).

Specimens MB.C.9081.5 (23 mm dm) und MB.C.9081.6 (19 $\mathrm{mm} \mathrm{dm}$ ) show the morphology of the intermediate growth stage, in which the conch is pachyconic $(\mathrm{ww} / \mathrm{dm}=0.65-0.70)$. Flanks and venter are broadly rounded, and the conch is thickest at the inner flank. Both specimens possess a very narrow umbilicus (uw/dm 0.08). The ornament of the two specimens consist of fine spiral lines, approximately 130 on flanks and venter, and very fine growth lines (Fig. 29C, D).

MB.C.9081.7 is one of the smallest specimens (Fig. 29G, H). It has, at $13 \mathrm{~mm} \mathrm{dm}$, a thickly pachyconic shape (ww/dm 0.80) with an almost closed umbilicus. The shell is covered by delicate spiral lines, which are best visible on the inner flanks around the umbilicus. Growth lines are also visible, they are periodically strengthened and run almost linear across the flanks to bend back for a wide and shallow ventral sinus.

Holotype MB.C.9081.1 allows the study of the suture line, which is characteristic for a member of Hypergoniatites (Fig. 30D). A V-shaped external lobe is very narrow at its base, with strongly diverging, almost straight flanks. At half height, the lobe is only little more than half as wide as
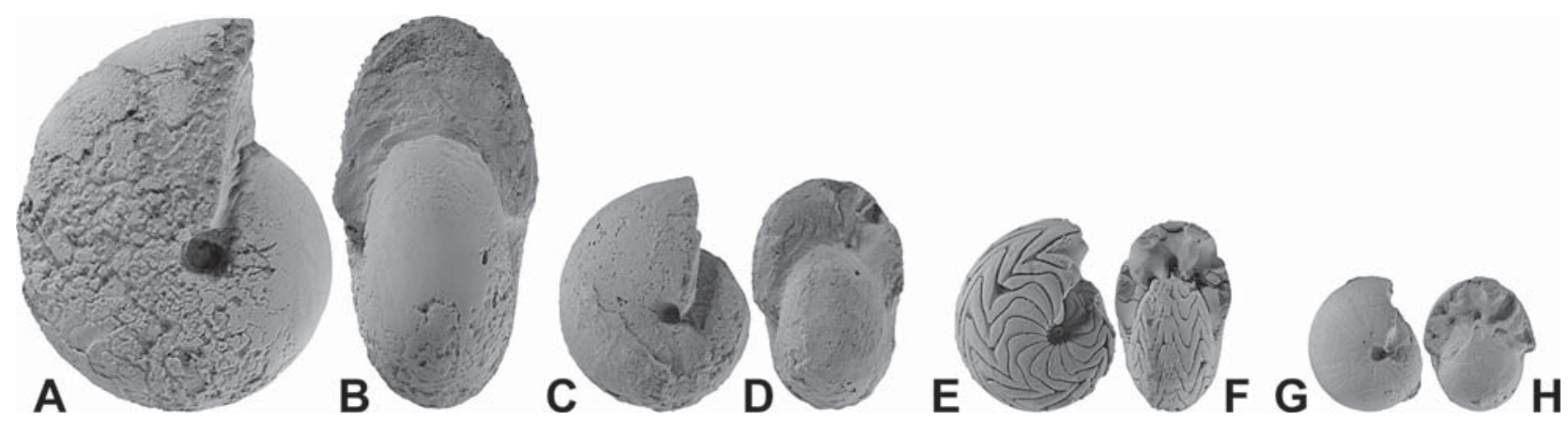

Fig. 29. Hypergoniatites fusiger n. sp. from Horizon GI-4 of the Gara el Itima; all $\times 1$. A, B - holotype MB.C.9081.1; C, D holotype MB.C.9081.5; E, F - paratype MB.C.9095.1; G, H - paratype MB.C.9081.7. 

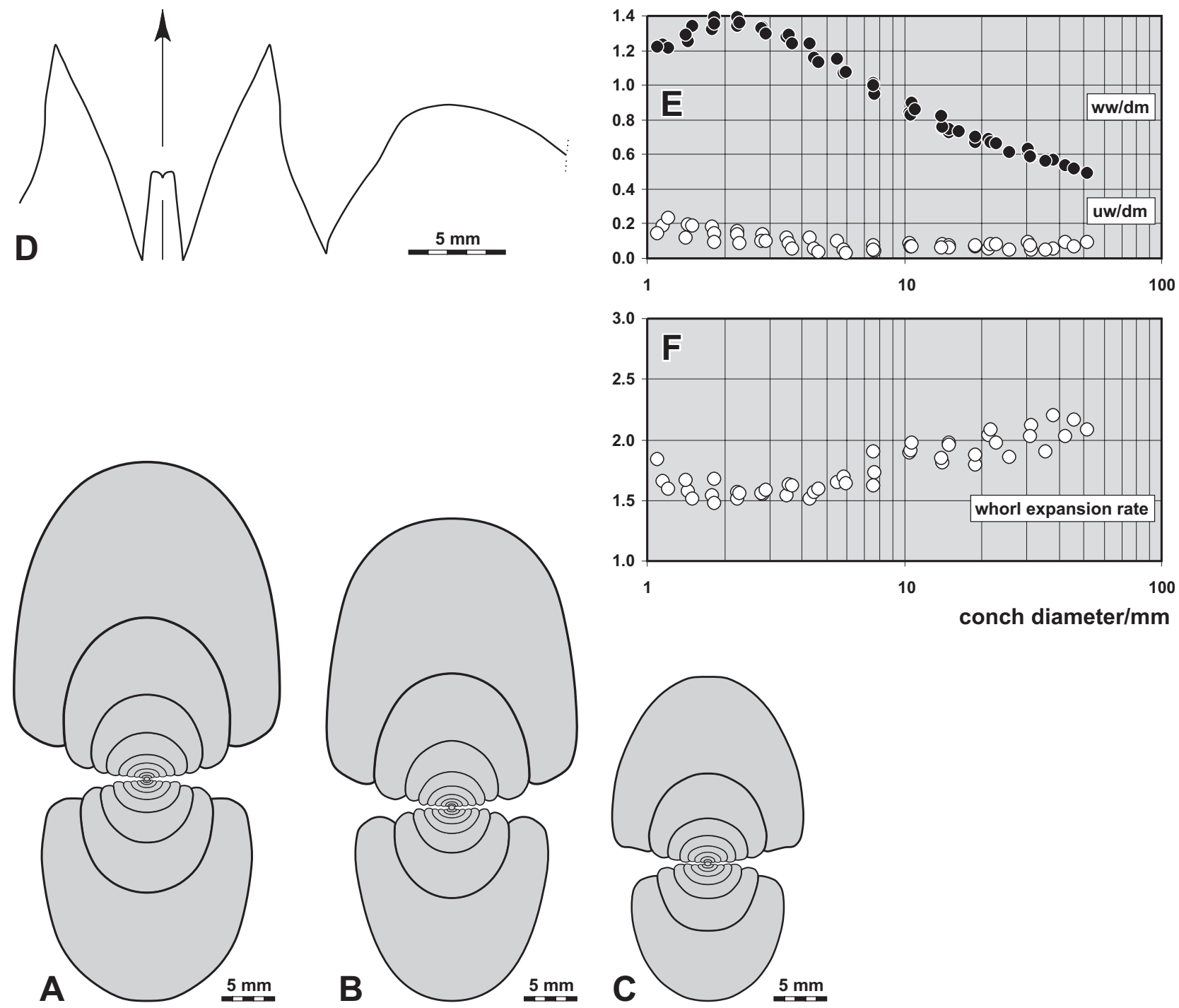

Fig. 30. Hypergoniatites fusiger n. sp. from Horizon GI-4 of the Gara el Itima. A - Cross section, paratype MB.C.9081.2; $\times 1.5$; B - Cross section, paratype MB.C.9081.3; × 1.5; C - Cross section, paratype MB.C.9081.4; $\times 1.5 ; \mathbf{D}-$ Suture line, holotype MB.C.9081.1, at $16.5 \mathrm{~mm}$ ww, $13.0 \mathrm{~mm}$ wh; $\times 2.75 ; \mathbf{E}-$ Ontogenetic development of the whorl width index (ww/dm) and umbilical width index (uw/dm); F - Ontogenetic development of the whorl expansion rate (WER).

deep. A narrow, rather low median saddle $(0.40$ of the external lobe depth) is visible. The ventrolateral saddle is acute and almost symmetric, and so is the $\mathrm{V}$-shaped adventive lobe.

Discussion. Hypergoniatites fusiger differs from the Cantabrian H. reticulatus Wagner-Gentis, 1980 in a number of characters: the umbilicus is almost closed in the latter species, the spiral ornament is weaker, constrictions are lacking, and, according to the suture drawing, the external lobe is narrower. H. tenuiliratus Ruzhencev \& Bogoslovskaya, 1971 has a similar conch shape and ornament, but possesses a much narrower external lobe with a lower median saddle. H. exiguus Ruzhencev \& Bogoslovskaya, 1971 lacks spiral ornament.

\section{Neogoniatites Ruzhencev \& Bogoslovskaya, 1970}

Type species. Neogoniatites milleri Ruzhencev \& Bogoslovskaya, 1970

\section{Neogoniatites worki n. sp.}

Figs 31B, 32, 33

Derivation of name. After David Work (Augusta), to acknowledge his contribution to Carboniferous palaeontology.

Holotype. Specimen MB.C.9091.1 (coll. Ebbighausen and Korn 2004); figured here in Fig. 32C, D.

Type locality and horizon. Gara el Itima, southeastern Anti-Atlas, Morocco; Horizon GI-3 (uppermost Zrigat Formation), latest Viséan.

Material. 12 specimens between 20 and $53 \mathrm{~mm}$ conch diameter; five of these came from Horizon GI-3 and seven from Horizon GI-4. 


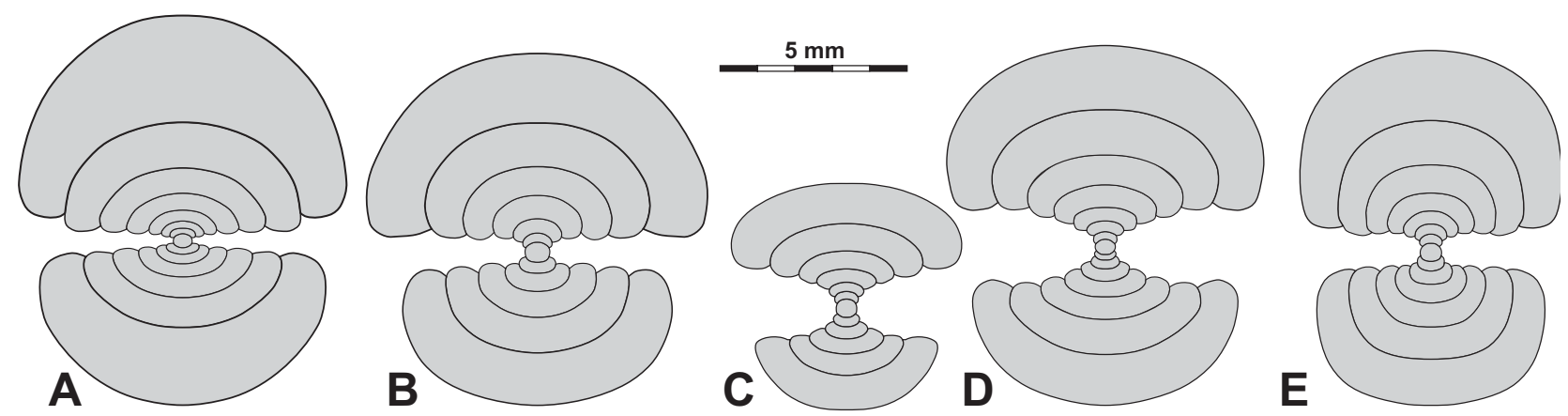

Fig. 31. Cross sections of the internal whorls of various species of the superfamily Goniatitoidea; all $\times 4$. A - Hypergoniatites fusiger n. sp., Horizon GI-4, paratype MB.C.9081.2; B - Neogoniatites worki n. sp., Horizon GI-4, paratype MB.C.9074.1; C - Dombarites granofalcatus (Kullmann, 1961), Horizon GI-3, specimen MB.C.3773; D - Dombarites granofalcatus (Kullmann, 1961), Horizon GI-3, specimen MB.C.9090.1; E - Platygoniatites rhanemensis n. sp., Horizon GI-4, paratype MB.C.9079.4.

Diagnosis. Species of Neogoniatites with globular conch at 4-9 $\mathrm{mm}$ diameter (ww/dm 1.00), globular conch (ww/dm $0.85)$ at $20 \mathrm{~mm}$ diameter, and pachyconic conch (ww/dm $0.70)$ at $40 \mathrm{~mm}$ diameter. Umbilicus very narrow in all stages larger than $5 \mathrm{~mm} \mathrm{dm}$ (uw/dm 0.05-0.15). Ornamentation with biconvex and rectiradiate growth-lines and 170 fine spiral lines. Suture line with rather wide external lobe $(0.65$ of the external lobe depth), and high median saddle (0.55 of the external lobe depth).

Description. The sectioned paratype MB.C.9074.1 displays the conch morphology up to a diameter of $38 \mathrm{~mm}$ (Figs 31B, 33A). At first glance, there appear to be little ontogenetic changes, particularly in the whorl width/conch diameter ratio. However, there is a low early ontogenetic depression in this ratio, a heightening to a maximum of approximately 1.00 between 4 and $9 \mathrm{~mm}$ diameter, and a subsequent decrease. The umbilicus opens in early ontogeny to a value of 0.30 at $2 \mathrm{~mm} \mathrm{dm}$, and thereafter, a slow de-
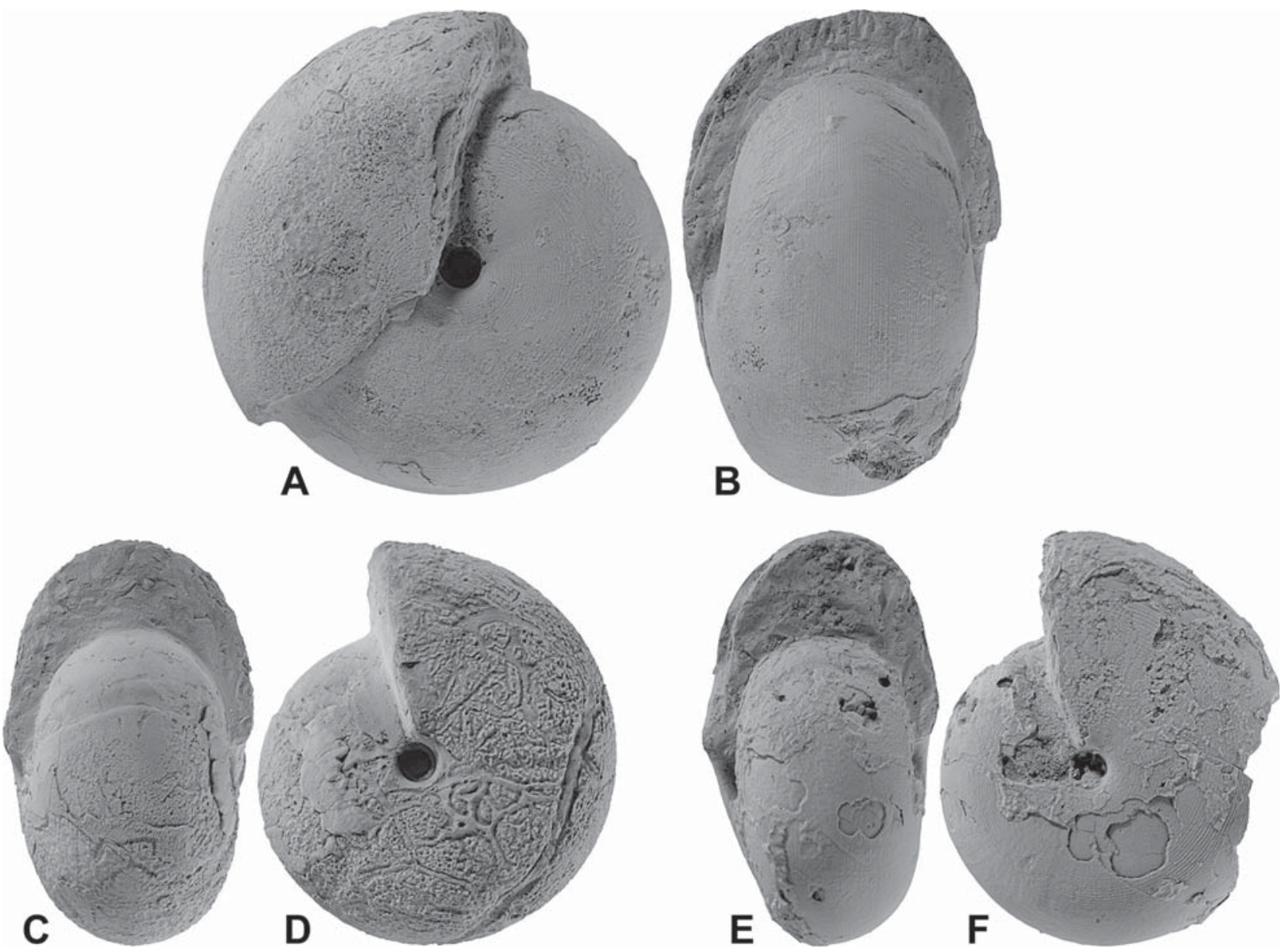

Fig. 32. Neogoniatites worki n. sp. from horizons GI-3 (A-D) and GI-4 (E-F) of the Gara el Itima; all $\times 1$; $\mathbf{A}, \mathbf{B}-$ paratype MB.C.9091.2; C, D - holotype MB.C.9091.1; E, F - paratype MB.C.9074.3. 
crease can be observed. The minimum lies between 10 and $20 \mathrm{~mm} \mathrm{dm}$, where the uw/dm ratio is $0.06-0.07$. In later stages, the umbilicus opens slowly. All growth stages show broadly rounded flanks and venter, and a rounded umbilical wall.

The shell is best preserved in paratype MB.C.9091.2 from Horizon GI-3 (Fig. 32A, B). At $40-50 \mathrm{~mm}$ conch diameter, there are $170 \mathrm{de}$ licate spiral lines on flanks and venter. They are arranged in regular distances; on the venter they are as wide as their interspaces, but around the umbilicus, they are much finer. Fine growth lines run with biconvex course with low projections and shallow sinuses across flanks and venter. The steinkern possesses wide and low constrictions, which follow the course of the growth lines.

In specimen MB.C.9074.2, the outer whorls are partly broken away, and hence an inner whorl is exposed. It is a pachyconic conch at $44 \mathrm{~mm}$ conch diameter $(\mathrm{ww} / \mathrm{dm}=0.67)$ with a very narrow umbilicus $(\mathrm{uw} / \mathrm{dm}=0.08)$, and has broadly rounded flanks and venter. Spiral lines can be seen on the weathered shell of the last whorl, and the steinkern bears rather deep radial constrictions. In the inner whorl, at approximately $25 \mathrm{~mm}$ conch diameter, there a steinkern constrictions with linear course, standing $90^{\circ}$ apart.

Holotype MB.C.9091.1 displays the suture line (Fig. 33B). It has a rather wide, V-shaped external lobe ( 0.65 of its depth; 1.20 of the adventive lobe) with sinuous flanks and a narrow median saddle that reaches a height of 0.58 of the lobe depth. The ventrolateral saddle is almost symmetric and acute, and the adventive lobe is asymmetric with convex flanks. The dorsolateral saddle is much lower than the ventrolateral saddle.

Discussion. Neogoniatites delicatus Korn et al., 1999 is another Moroccan species, and it also possesses a shell that is ornamented with delicate spiral lines. This species differs from $N$. worki in the higher aperture, with a whorl expansion rate between 1.75 and 1.90 at $20-40 \mathrm{~mm} \mathrm{dm}$. By contrast, the WER reaches only 1.55-1.65 in the new species.

The new species differs from $N$. milleri Ruzhencev \& Bogoslovskaya, 1970 in the presence of spiral lines, the narrower external lobe and the lower median saddle. N. ruginosus Ruzhencev \& Bogoslovskaya, 1971 has a similar suture line, but has a much more slender conch, with a ww/dm ratio always approximately 0.10 lower than the new species.
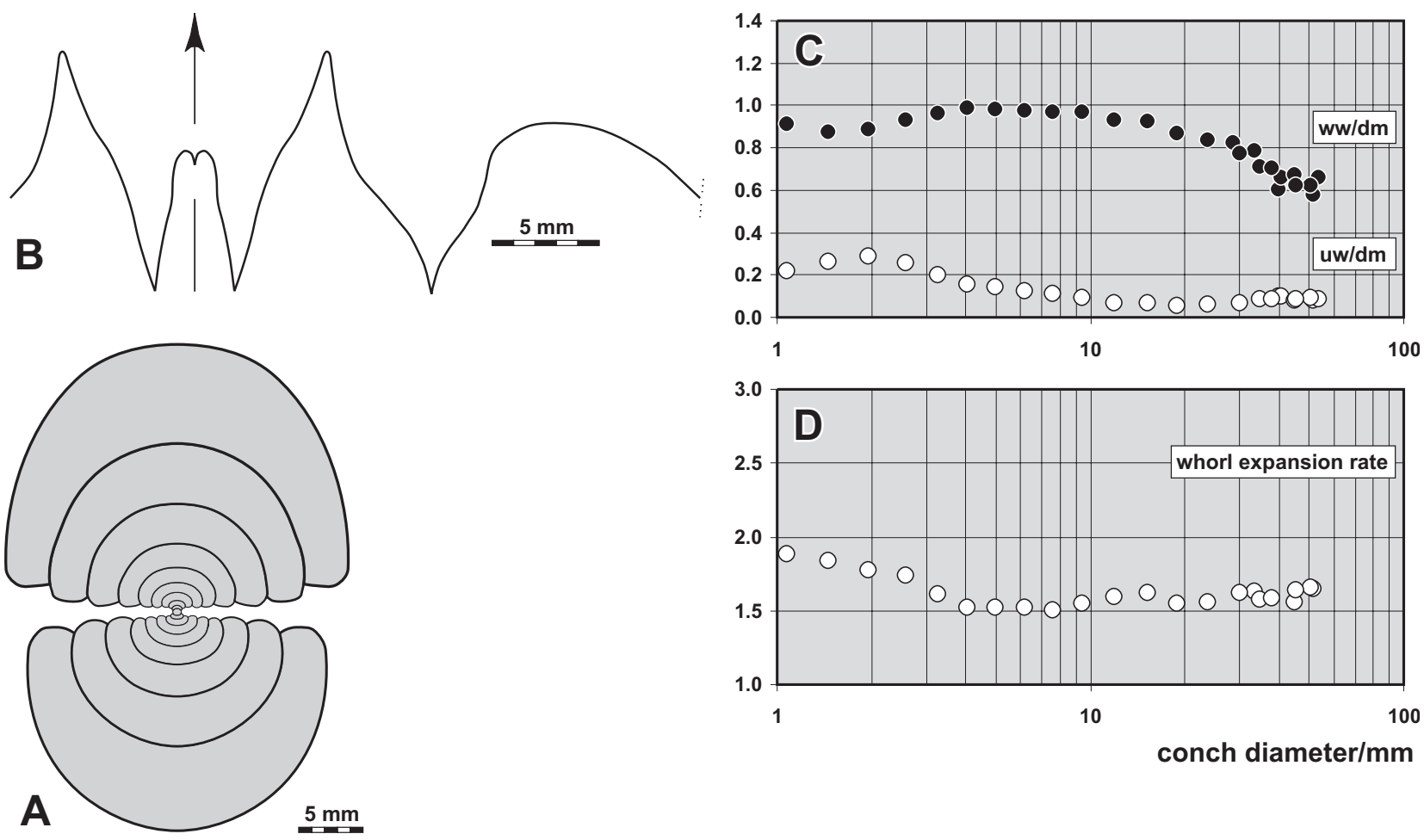

Fig. 33. Neogoniatites worki n. sp. from horizons GI-3 and GI-4 of the Gara el Itima. A - Cross section, paratype MB.C.9074.1; $\times 1.5 ; \mathbf{B}-$ Suture line, holotype MB.C.9091.1, at $24.2 \mathrm{~mm}$ ww, $16.0 \mathrm{~mm}$ wh; $\times 2.5 ; \mathbf{C}-$ Ontogenetic development of the whorl width index $(w w / d m)$ and umbilical width index (uw/dm); D - Ontogenetic development of the whorl expansion rate (WER). 
Family Agathiceratidae von Arthaber, 1911

\section{Dombarites Librovitch, 1957}

Type species. Dombarites tectus Librovitch, 1957

Discussion. Wagner-Gentis (1980) erected the genus Revilloceras for those goniatites of early agathiceratids (or advanced goniatitids) in which the flanks of the external lobe do not diverge as much as in most of the species of Dombarites, but are more parallel-arranged in the lower half. After its original description, the genus was obviously never treated as a valid taxon. The difference in the shape of the external lobe, Y-shaped in Revilloceras, cannot be regarded as a criterion to separate the genus. It is therefore treated as junior synonym of Dombarites.

\section{Dombarites granofalcatus (Kullmann, 1961)} Figs 31C, D, 34, 35

1961 Goniatites (Goniatites) granofalcatus Kullmann: 305, pl. 22: figs 1, 2.

1963b Goniatites (Goniatites) granofalcatus. - Kullmann: 190, pl. 6: figs 3, 4.

? 1963 Mesoglyphioceras granosus var. barruelensis. Wagner-Gentis: 11, pl. 1: fig. 1, pl. 2: fig. 1, pl. 5: fig. 1.

1980 Dombarites granofalcatus. - Wagner-Gentis: 10, pl. 1: figs 2-4.

? 1980 Dombarites cantina. - Wagner-Gentis: 12, pl. 4: fig. 5.

? 1980 Revilloceras barruelense.- Wagner-Gentis: 14, pl. 5: figs 2, 3,

?1980 Revilloceras globosum. - Wagner-Gentis: 16, pl. 5: fig. 1 ,

1999 Dombarites granofalcatus. - Korn, Klug \& Mapes: 358, pl. 5: figs $1-3$.

2004 Dombarites granofalcatus. - Korn, Klug \& Mapes: 88, fig. 2D, E.

Holotype. Specimen IGT 1160/513 (coll. Kullmann); figured by Kullmann (1961) on pl. 22: fig. 1.

Type locality and horizon. Ruada Mountain, Montó Region (León Province, Cantabrian Mountains, Spain); red nodular limestone of the "Marbre Griotte" (Alba Formation); probably latest Viséan.

Material. 75 specimens between 24 and $85 \mathrm{~mm}$ conch diameter, of which three are stored in the collection of the Institut für Geowissenschaften, University of Tübingen, and the remainder in the Museum für Naturkunde, Berlin. Approximately half of the specimens are fragments. All come from Horizon GI-3 (uppermost Zrigat Formation), latest Viséan; Gara el Itima, southeastern Anti-Atlas, Morocco.

Diagnosis. Species of Dombarites with variable, thickly pachyconic to globular conch at $20 \mathrm{~mm}$ diameter (ww/dm $0.72-0.88$ ), pachyconic conch (ww/dm $0.64-0.72)$ at $40 \mathrm{~mm}$ diameter and pachyconic conch (ww/dm $0.55-0.65)$ at $60 \mathrm{~mm}$ diameter. Umbilicus wide in early growth stages, narrow at $20 \mathrm{~mm} \mathrm{dm}$ (uw/dm 0.12-0.24), and opening in adult conchs (uw/dm $0.24-0.28$ at $60 \mathrm{~mm} \mathrm{dm}$ ). Ornamentation with $80-90$ coarse spiral lines and fine but rhythmically strengthened, crenulated growth lines with biconvex and rursiradiate course. External sinus wide and rather deep. Suture line with moderately wide, Y-shaped external lobe $(0.65-0.75$ of the external lobe depth), and moderately high saddle ( 0.50 of the external lobe depth).

Description. The morphometric plot demonstrates the wide variability of the species, but it is clear that this variability is different in the various growth stages (Fig. $35 \mathrm{G}, \mathrm{H}$ ). What can be stated is that variability is much more expressed in juveniles and immature conchs, but the mature conchs are rather similar.

Five cross sections were produced to gain information on the ontogenetic development and the intraspecific variability. Of these sections, specimen MB.C.9090.1 (Fig. 35A) displays twelve whorls from the initial stage to the mature stage at $66 \mathrm{~mm}$ conch diameter, and the others (MB.C.3773, MB.C.3774, MB.C.9031.1, MB.C.9090.2) show aspects of juvenile or adult morphology (Figs 31C, D, 35B-D). Specimen MB.C.9090.1 has a juvenile morphology with wide umbilicus and low, ventrally depressed whorls. Between 1.2 and $2.5 \mathrm{~mm}$ conch diameter, the uw/dm ratio exceeds a value of 0.40 , and thereafter, this ratio decreases continuously to a minimum of $0.15-0.17$ between 11 and $30 \mathrm{~mm}$ diameter. Subsequently, the umbilicus opens in the adult stage toward 0.24 at $66 \mathrm{~mm} \mathrm{dm}$. The three-fold ontogeny can also be observed in the whorl width/conch diameter ratio. The conch begins pachyconic and becomes globiform (ww/dm $>0.85$ ) between 2 and $10 \mathrm{~mm}$ diameter; with a maximum of 0.96 from 3.5 to $5.5 \mathrm{~mm} \mathrm{dm}$. Above this diameter, there is a continuous decrease in the ww/dm ratio towards less than 0.60 at $66 \mathrm{~mm}$ $\mathrm{dm}$. A character that is much less influenced by ontogenetic changes is the apertural height, expressed by the almost constant whorl expansion rate. After an early juvenile decrease, this rate remains stable around 1.50 throughout ontogeny. This means that the aperture is very low in the entire ontogeny, being responsible for the high number of whorls. Most of the whorls show broadly rounded flanks and a rounded venter, but at approximately $10 \mathrm{~mm} \mathrm{dm}$, there is a slight ventral depression, leading to the cuboid morphology (Korn et al. 2004). Stages larger than $20 \mathrm{~mm}$ dm show an almost rectangular umbilical margin, and the conch is widest at this place, with flanks slowly converging towards the venter.

Mostly large specimens are available for study. At $65 \mathrm{~mm}$ conch diameter (specimen IGT 1851-93), the thinly pachyconic conch (ww/ $\mathrm{dm}=0.64$ ) has a relatively wide umbilicus (uw/ $\mathrm{dm}=0.27$ ) with angular margin (Fig. 34C, D). The conch is widest at the umbilicus, and the 


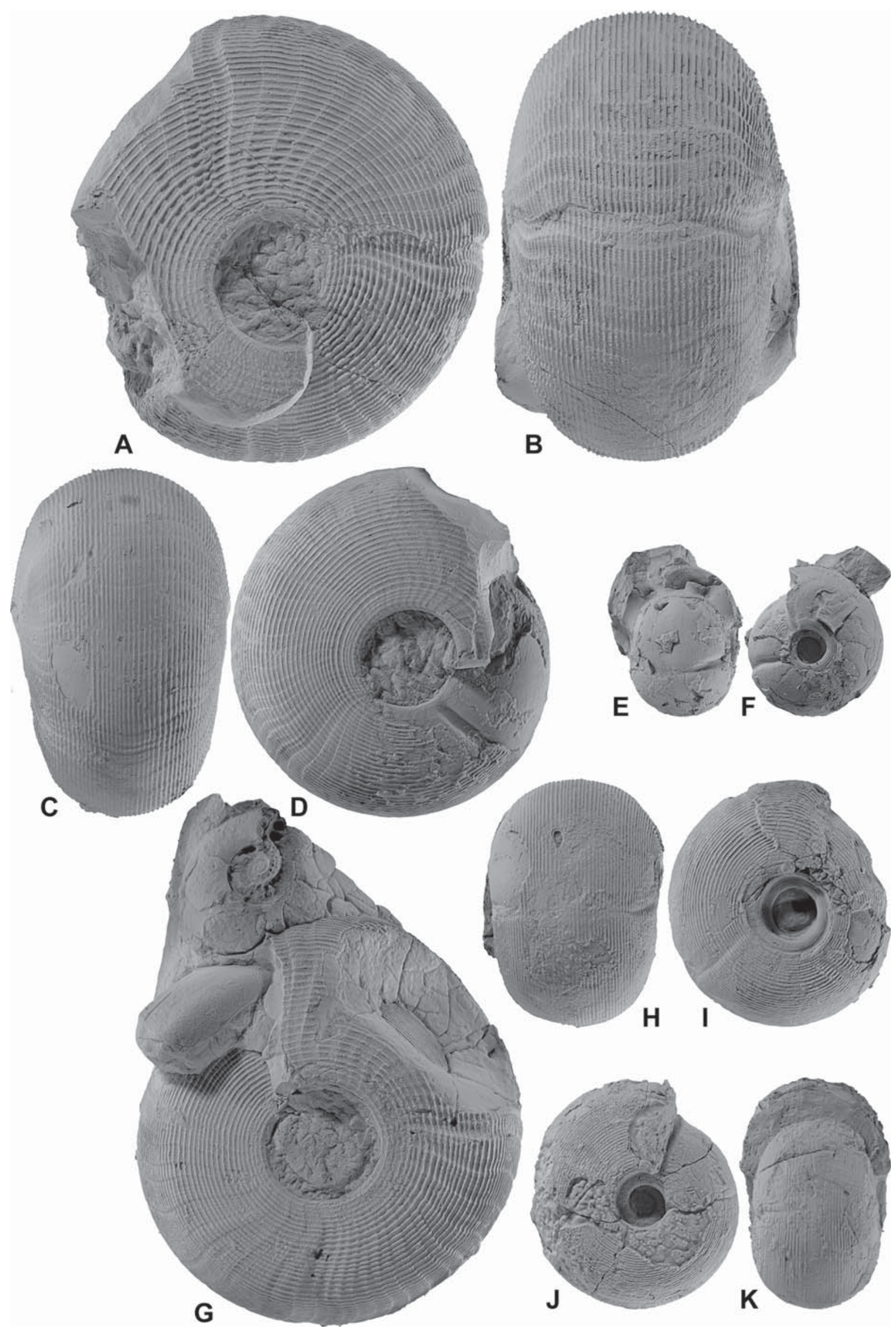

Fig. 34. Dombarites granofalcatus (Kullmann, 1961) from Horizon GI-3 of the Gara el Itima; all $\times 1$. A, B - specimen IGT 1851-95; C, D - specimen IGT 1851-93; E, F - specimen MB.C.9031.2; G - specimen IGT 1851-94; H, I - specimen MB.C.9090.3; J, K - specimen MB.C.9090.4. 

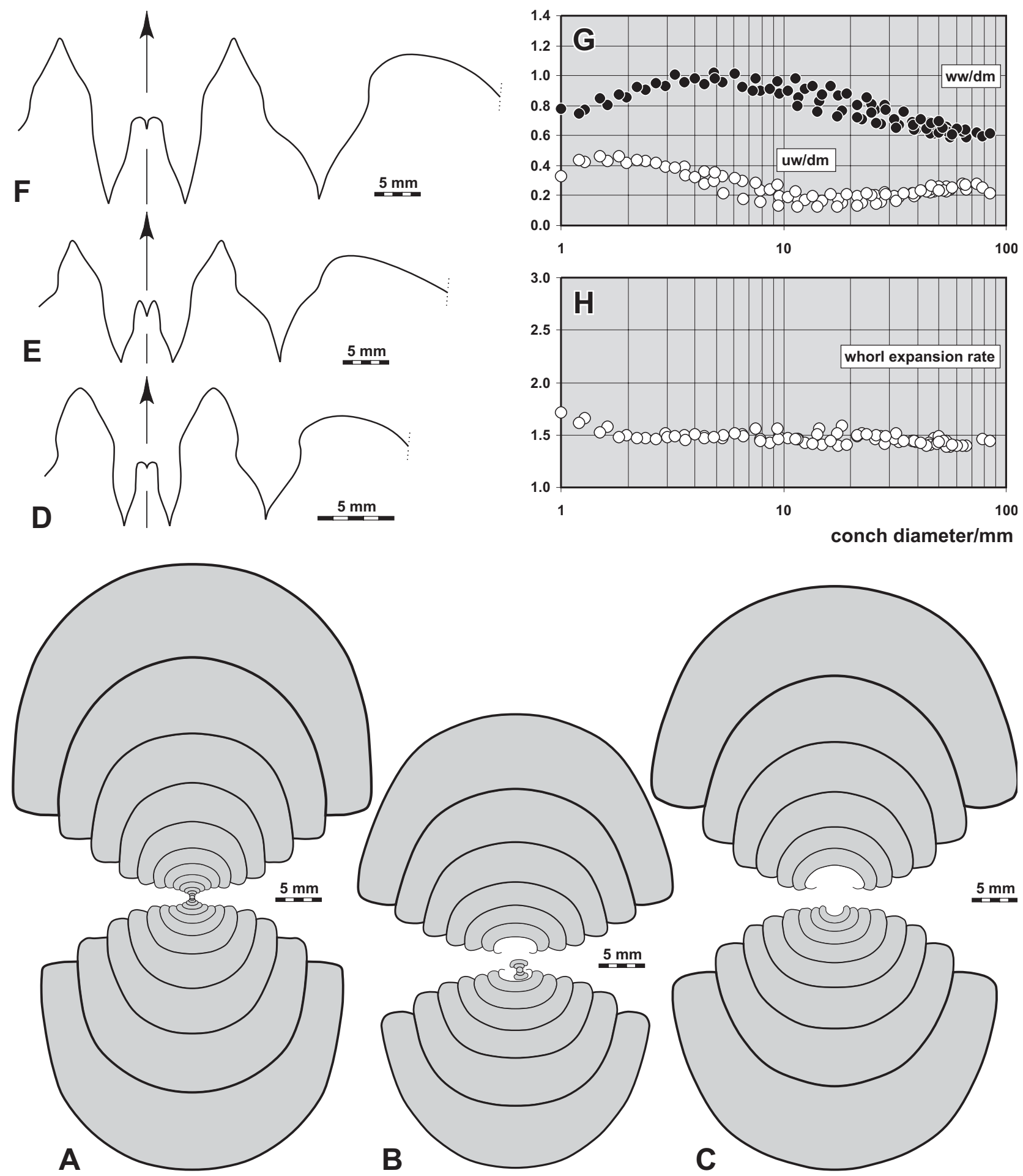

Fig. 35. Dombarites granofalcatus (Kullmann, 1961) from Horizon GI-3 of the Gara el Itima. A - Cross section, specimen MB.C. $9090.1 ; \times 1,5 ; \mathbf{B}-$ Cross section, specimen MB.C. $9090.2 ; \times 1,5 ; \mathbf{C}-$ Cross section, specimen MB.C.9031.1; $\times 1,5 ; \mathbf{D}-$ Suture line (reversed), specimen MB.C. 9031.2 , at $26.2 \mathrm{~mm} \mathrm{dm}$, ca. $21 \mathrm{~mm}$ ww, ca. $9.5 \mathrm{~mm}$ wh; $\times 2.5 ; \mathbf{E}-$ Suture line, specimen IGT 1851-93, at $32 \mathrm{~mm} \mathrm{ww;} \times 1,5 ; \mathbf{F}-$ Suture line (reversed), specimen MB.C.9031.3, at ca. $35 \mathrm{~mm}$ ww, $22.5 \mathrm{~mm}$ wh; $\times 1,5$. G - Ontogenetic development of the whorl width index (ww/dm) and umbilical width index (uw/dm); H - Ontogenetic development of the whorl expansion rate (WER).

flanks converge only slightly to continue into the broad and rounded venter. The two larger specimens IGT 1851-94 and 1851-95 are similar conchs; in both specimens is the aperture very low with a whorl expansion rate of approximately 1.45 .
The ornament of the specimens slightly suffered from aeolian weathering, but can be described in detail. Specimen IGT 1851-93 displays, at $65 \mathrm{~mm}$ conch diameter, 80 coarse and sharp spiral lines that are arranged in equal distances of $0.8-1.0 \mathrm{~mm}$. The growth lines are not well 
preserved in this specimen, but their rhythmic strengthening can be seen, beginning at $55 \mathrm{~mm}$ conch diameter. One volution bears four steinkern constrictions, which are only barely visible on the shell surface (Fig. 34C, D).

The larger specimens IGT 1851-94 (Fig. 34G) and 1851-95 (Fig. 35A, B) display the growth lines, which occur in distances of $0.4-0.5 \mathrm{~mm}$, and produce a granulation when crossing the spiral lines. About every tenth growth line is strengthened to form a relatively coarse radial ornament. The course of the growth lines is rursiradiate and biconvex with two lateral projections and a shallow and wide external sinus. Four constrictions of the shell are present on one volution.

The suture line of the immature specimen MB.C. 9031.2 has, at $26 \mathrm{~mm}$ conch diameter, a Yshaped external lobe in which the flanks stand parallel in the lover half (Fig. 35D). The prongs are lanceolate; the median saddle between them is narrow and raised to approximately 0.45 of the external lobe depth. The tectiform ventrolateral saddle is narrowly rounded, and the adventive lobe asymmetrically lanceolate; its ventral flank is strongly curved.

At $32 \mathrm{~mm}$ whorl width, corresponding to approximately $55 \mathrm{~mm}$ conch diameter, the suture line of specimen IGT 1851-93 has still a Yshaped external lobe with strongly sinuous flanks, and the subacute ventrolateral saddle has a tectiform outline. The ventral flank of the adventive lobe is stronger curved than the dorsal flank (Fig. 35E).

Specimen MB.C.9031.3 does not differ much from the preceding specimen. The ventral lobe has precisely a width of two thirds of the depth, and the median saddle raise a little higher than half of the E lobe depth. The width of the external lobe is 1.15 of the adventive lobe (Fig. 35F).

Discussion. It is demonstrated here that the species has a wide intraspecific variability, and hence, some of the species that were described on the base of conch morphology must be treated as synonyms. This is particularly the case in those species that came from the Alba Formation and its lateral equivalents of the Cantabrian Mountains, i.e., "Dombarites cantina WagnerGentis, 1980" and "Revilloceras globosum Wagner-Gentis, 1980". The first may only be a less stout variant of the species, and the second a more globiform. Even the type species of Revilloceras, "Revilloceras barruelense", may be a junior subjective synonym. It was, like the second of the other two putative synonyms, probably based on preadult specimens of approximately $35 \mathrm{~mm}$ conch diameter, in a growth interval that displays the widest variability. A revision of the Spanish material is required to solve this problem.

Dombarites granofalcatus has to be compared with those species of Dombarites, which possess a rather low median saddle. It is one of the most coarsely ornamented species of the genus. Other strongly ornamented species, such as D. falcatoides Ruzhencev \& Bogoslovskaya, 1970, D. parafalcatoides Ruzhencev \& Bogoslovskaya, 1971, D. masculus (Sheng, 1983), D. mapesi (Drahovzal \& Quinn, 1972), and D. bellornatus n. sp. have a much narrower umbilicus (uw/dm $0.10-0.15$ ), in contrast to 0.25 in D. granofalcatus. Another good character to distinguish between D. granofalcatus and other species is the strikingly rursiradiate direction of the growth lines, together with their rhythmical strengthening. The cardinal character, however, is the Yshaped external lobe of $D$. granofalcatus. This is probably an indication for a close relationship to the genus Platygoniatites, in which the prongs of the external lobe develop towards independent lobes.

\section{Dombarites bellornatus n. sp.}

Figs 36, 37

Derivation of name. After the Latin bellus = pretty and ornatus $=$ decorated, because of the beautiful ornament of the species.

Holotype. Specimen MB.C.9072.1 (coll. Kaiser); figured here in Fig. 36A, B.

Type locality and horizon. Gara el Itima, southeastern Anti-Atlas, Morocco; Horizon GI-6 (middle Hamou-Rhanem Formation), probably latest Viséan.

Material. 4 specimens between 28 and $70 \mathrm{~mm}$ conch diameter. Three of these, including the holotype come from Horizon GI-6 and one from Horizon GI-4.

Diagnosis. Species of Dombarites with globular conch between 5 and $12 \mathrm{~mm}$ diameter $(\mathrm{ww} / \mathrm{dm}=0.90)$ and pachyconic conch (ww/dm $0.60-0.65$ ) at $40 \mathrm{~mm}$ diameter. Umbilicus wide in early growth stages, narrow in stages larger than $8 \mathrm{~mm} \mathrm{dm}$ (uw/dm 0.10-0.16). Ornamentation with 90 spiral lines and fine but rhythmically strengthened, crenulated growth lines with biconvex and rursiradiate course. External sinus shallow. Suture line with moderately wide, V-shaped external lobe ( 0.65 of the external lobe depth), and moderately high saddle ( 0.50 of the external lobe depth).

Description. Specimen MB.C.9072.2 was cut for a cross section; it shows dislocated inner whorls but allows to observe the ontogeny between 4 and $28 \mathrm{~mm}$ conch diameter (Fig. 37A). The conch has a cuboid shape between approximately 4 and $8 \mathrm{~mm} \mathrm{dm}$, with a narrow umbilicus 

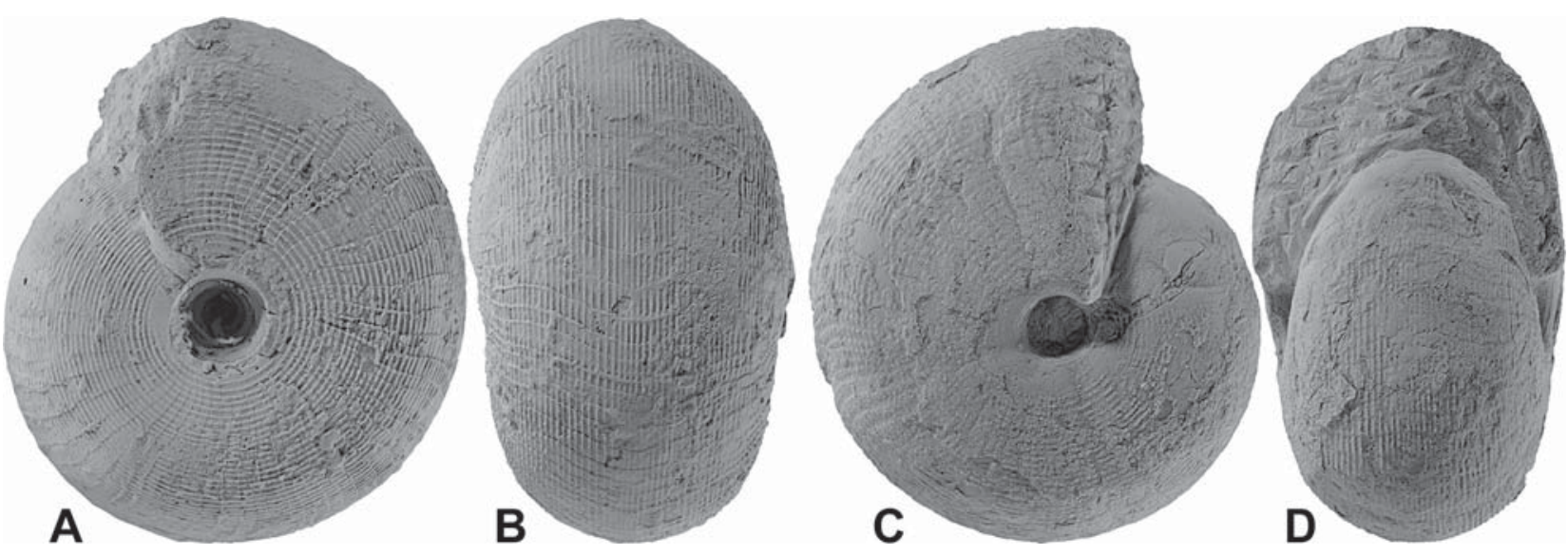

Fig. 36. Dombarites bellornatus n. sp. from Horizon GI-6 of the Gara el Itima; all × 1. A, B - holotype MB.C.9072.1; C, D paratype MB.C.9061.

(uw/dm $=0.16-0.24)$, a low aperture, and a slightly flattened venter. In later stages is the venter broadly rounded and continues into the flanks. The conch is thickest in the midflank area. The aperture is low in all the preserved stages, the whorl expansion rate is always close to 1.50 .

The well-preserved holotype MB.C.9072.1 displays all ornament details (Fig. 36A, B). 90 spiral lines standing in equal distances in this specimen with $55 \mathrm{~mm}$ conch diameter. Growth lines are much finer, they run rursiradiate with a weekly biconvex course across flanks and venter, with a rather high dorsolateral projection and a shallow, wide external sinus. The growth lines are periodi- cally strengthened, each 15 th growth line in average, and lead to a weak falcate ornament. At the crossings of spiral lines and growth lines, a granulation is produced. The steep and flattened umbilical wall possesses coarse growth lines and lacks spirals.

Paratype MB.C.9061 has a very similar conch morphology and ornament (Fig. 36C, D). The conch is thinly pachyconic $(\mathrm{ww} / \mathrm{dm}=0.61)$ at $55 \mathrm{~mm}$ conch diameter, with a narrow umbilicus (uw/dm $=0.11$ ). The aperture is comparatively high, with a whorl expansion rate of 1.73 .

The suture line of specimen MB.C.9072.2 has a V-shaped, rather wide external lobe with
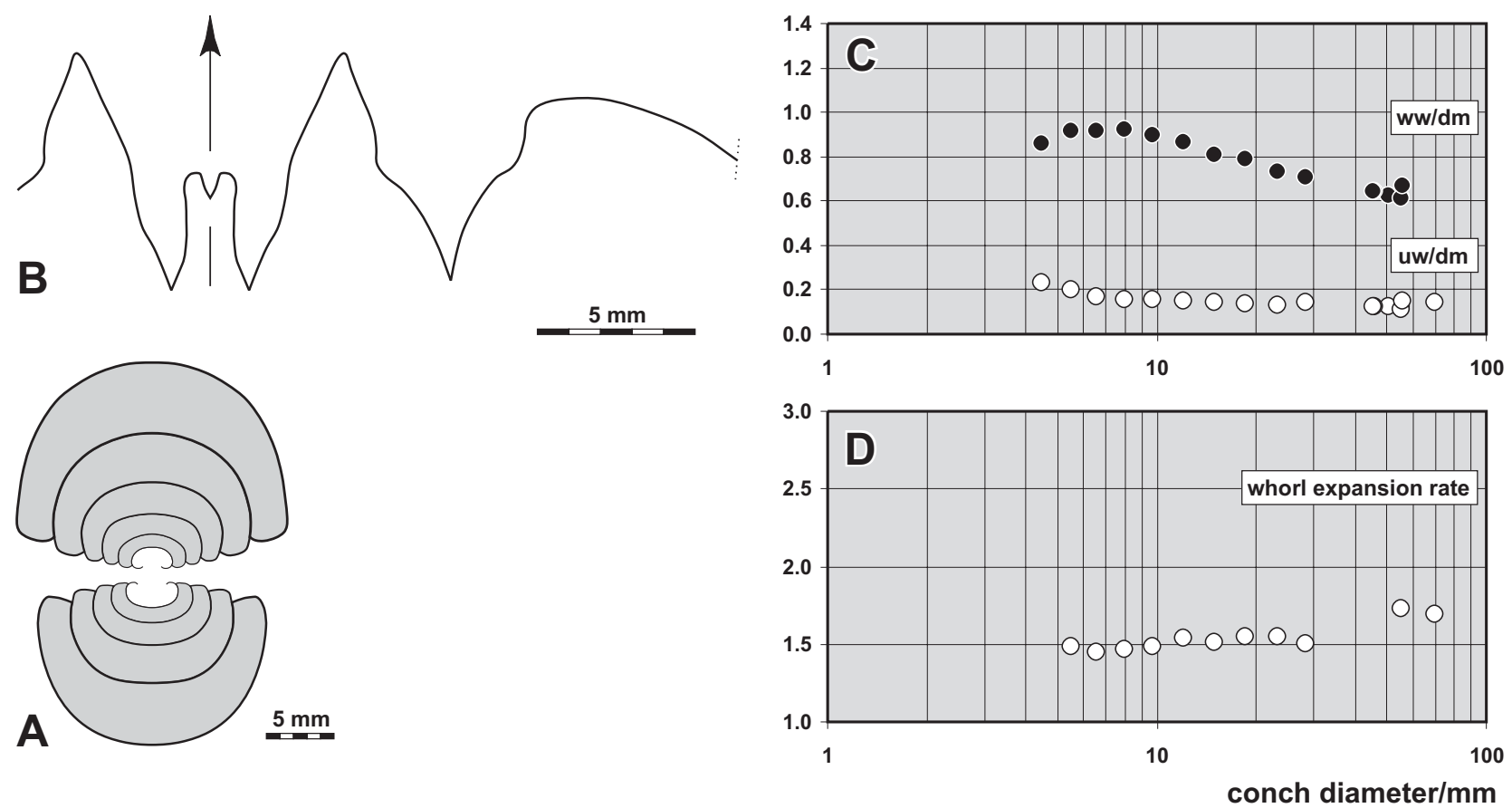

Fig. 37. Dombarites bellornatus n. sp. from Horizon GI-6 of the Gara el Itima. A - Cross section, specimen MB.C.9072.2; $\times 1.5 ; \mathbf{B}$ - Suture line (reversed), specimen MB.C.9072.2, at $18.7 \mathrm{~mm}$ ww, $12.3 \mathrm{~mm} \mathrm{wh;} \times 3.5 ; \mathbf{C}-$ Ontogenetic development of the whorl width index (ww/dm) and umbilical width index (uw/dm); D - Ontogenetic development of the whorl expansion rate (WER). 
strikingly sinuous but continuously diverging flanks (Fig. 37B). At half height, the lobe has a width of exactly two thirds of the depth, and the median saddle has exactly half the height of the total lobe depth. The ventral flanks of the lanceolate, asymmetric prongs are almost parallel. The ventrolateral saddle is slightly asymmetric and subacute, followed by an adventive lobe with angularly sinuous flanks. The ratio $\mathrm{E}$ lobe/A lobe width, measured at half depth, is 1.28:1.

Discussion. Dombarites bellornatus n. sp. is an early species of the genus, in which the median saddle is still rather low. D. parafalcatoides $\mathrm{Ru}$ zhencev \& Bogoslovskaya, 1971 is a rather similar species, but differs in some characters: D. parafalcatoides has, at comparable conch diameters, a more slender conch, a narrower umbilicus, and a higher aperture. The growth lines are rectiradiate in this species, in contrast to the rursiradiate lines of $D$. bellornatus. The flanks of the external lobe are much more sinuous in D. bellornatus. The other species of Dombarites differ in their higher median saddle, being higher than 0.60 of the external lobe depth.

\section{Family Delepinoceratidae Ruzhencev, 1957}

\section{Platygoniatites Ruzhencev, 1956}

Type species. Platygoniatites molaris Ruzhencev, 1956.

\section{Platygoniatites rhanemensis $\mathbf{n} . \mathbf{s p}$.}

Figs 31E, 38-41

Derivation of name. After the Hamou Rhanem, after which the ammonoid-bearing formation is named.

Holotype. Specimen MB.C.9079.1 (coll. Ebbighausen and Korn 2004); figured here in Fig. 38A, B.

Type locality and horizon. Gara el Itima, southeastern Anti-Atlas, Morocco; Horizon GI-4 (basal Hamou-Rhanem Formation), probably latest Viséan.

Material. 215 specimens between 20 and $125 \mathrm{~mm}$ conch diameter, of which one fourth are fragments.

Diagnosis. Species of Platygoniatites with thickly pachyconic conch at $10 \mathrm{~mm}$ diameter (ww/dm $0.75-0.85$ ), thickly discoidal or thinly pachyconic conch at $40 \mathrm{~mm} \mathrm{dm} \mathrm{(ww/dm}$ $0.55-0.65$ ) and thickly discoidal (ww/dm $0.45-0.55$ ) at $80 \mathrm{~mm}$ diameter. Umbilicus wide in early growth stages, narrow in stages larger than $8 \mathrm{~mm} \mathrm{dm}$ (uw/dm 0.10-0.16). Umbilicus opening in stages larger than $25 \mathrm{~mm} \mathrm{dm}$ to a uw/dm ratio of 0.25 . Ornamentation with 90 spiral lines and fine but rhythmically strengthened, crenulated growth lines with biconvex and rursiradiate course. External sinus wide and rather deep. Suture line with wide external lobe (0.80-0.90 of the external lobe depth), and moderately high saddle ( 0.50 of the external lobe depth).
Description. Most of the specimens range, in their conch dimensions, between 30 an $90 \mathrm{~mm}$, and hence this interval is best documented by morphometric data (Fig. 41G, H). The range of variability can be regarded as normal in comparison with other goniatite species, and there occurs a continuous decrease in the ww/dm ratio from $0.57-0.67$ at $30 \mathrm{~mm}$ dm towards $0.45-0,52$ at $80-90 \mathrm{~mm} \mathrm{dm}$. At the same time, the umbilicus is almost continuously opened from a uw/dm ratio of $0.10-0.15$ towards $0.18-0.23$.

A number of cross sections were produced to study the ontogeny of the conch; some of them are figured in Fig. 41A-D. Cross section MB.C.9051.1 allows a complete insight in the ontogenetic development of the conch up to a stage of $47 \mathrm{~mm} \mathrm{dm}$. The earliest whorls up to approximately $10 \mathrm{~mm} \mathrm{dm}$ are globular (ww/dm 0.90) without significant ontogenetic changes. Only the width of the umbilicus shows a trend, with a maximum value of 0.30 at $2 \mathrm{~mm} \mathrm{dm}$ and a subsequent decrease to 0.10 at $26 \mathrm{~mm} \mathrm{dm}$. After $10 \mathrm{~mm} \mathrm{dm}$, the relative width of the conch becomes lesser, and at $47 \mathrm{~mm} \mathrm{dm}$, it has only 0.55 of the conch diameter. The aperture is low in all stages, with a whorl expansion rate that ranges between 1.40 and 1.50 in stages from 3 to $47 \mathrm{~mm}$ $\mathrm{dm}$. Some growth stages display a cuboid outline of the whorl section, best visible between 7 and $15 \mathrm{~mm} \mathrm{dm}$. Almost all whorls show a rather distinct, sometimes subangular umbilical margin. Similar cross sections can be seen in the other sectioned paratypes MB.C.9079.2, MB.C.9079.3, and MB.C.9079.4.

Many specimens are, though somewhat eroded, well preserved and display the shell ornament. In the largest specimen MB.C.9079.5 $(125 \mathrm{~mm} \mathrm{dm})$, there are approximately 90 spiral lines on flanks and venter, they are arranged in distances of 1 to $1.5 \mathrm{~mm}$. The growth lines are finer than the spirals, they possess a prominent dorsolateral projection and run then in backward direction across the flanks to form a much less pronounced ventrolateral projection and a deep, semicircular ventral sinus. At the crossings with the spiral lines, they cause a distinct granulation. There is a periodical strengthening of the transverse ornament in distances of 8 to 12 growth lines, i.e., with irregular spaces of 4 to $8 \mathrm{~mm}$ on the venter.

The rhythmic strengthening of the growth lines is a mature character of the ornament. In the specimens MB.C.9079.6 (Fig. 39A, B) and MB.C.9079.1 (the holotype; Fig. 38A, B) it appears at 66 and $77 \mathrm{~mm}$ conch diameter, respec- 

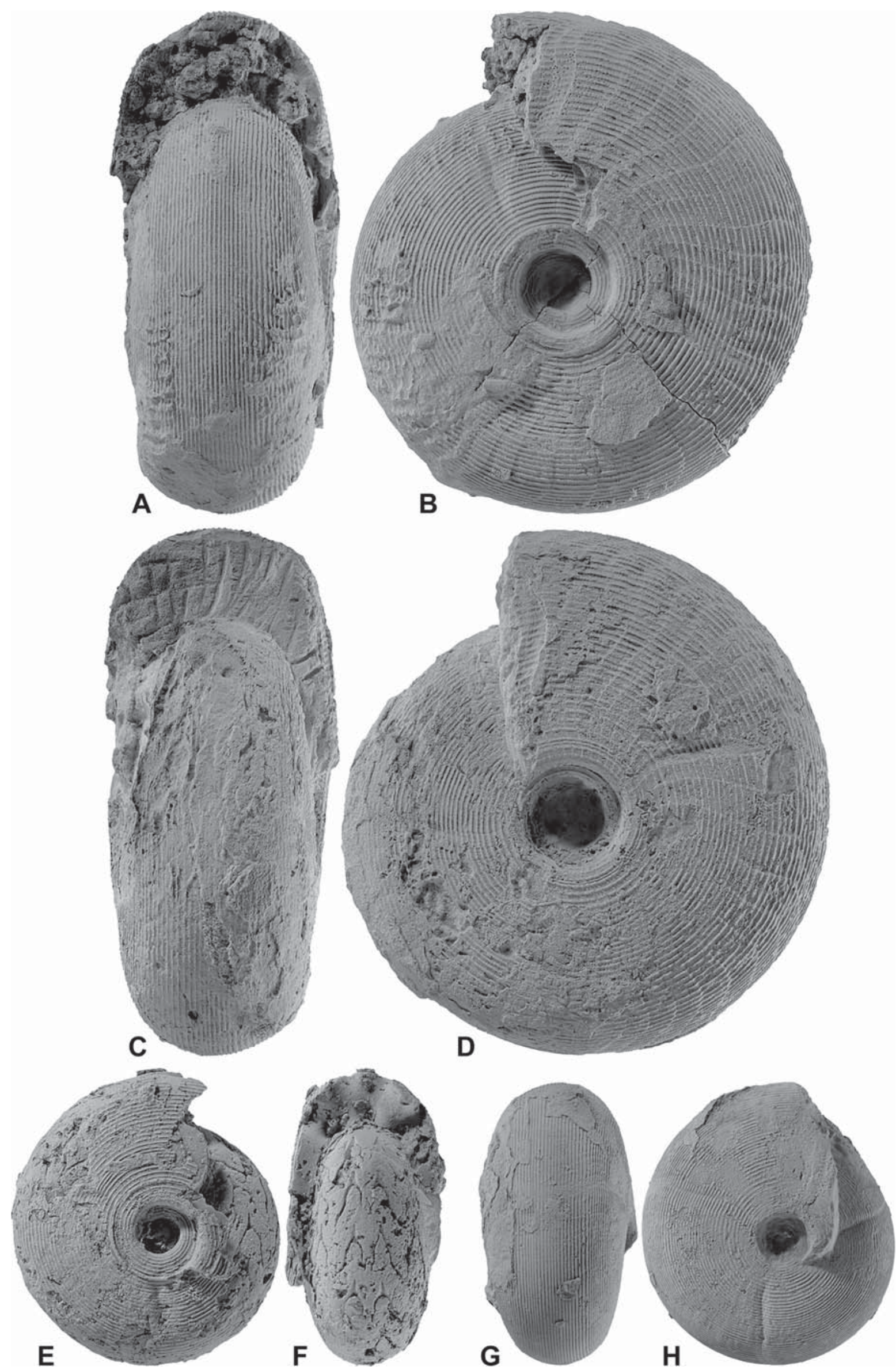

Fig. 38. Platygoniatites rhanemensis n. sp. from Horizon GI-4 of the Gara el Itima; all $\times 1$. A, B - holotype MB.C.9079.1; C, D - paratype MB.C.9079.11; E, F - paratype MB.C.9079.12; G, H - paratype MB.C.9079.7. 

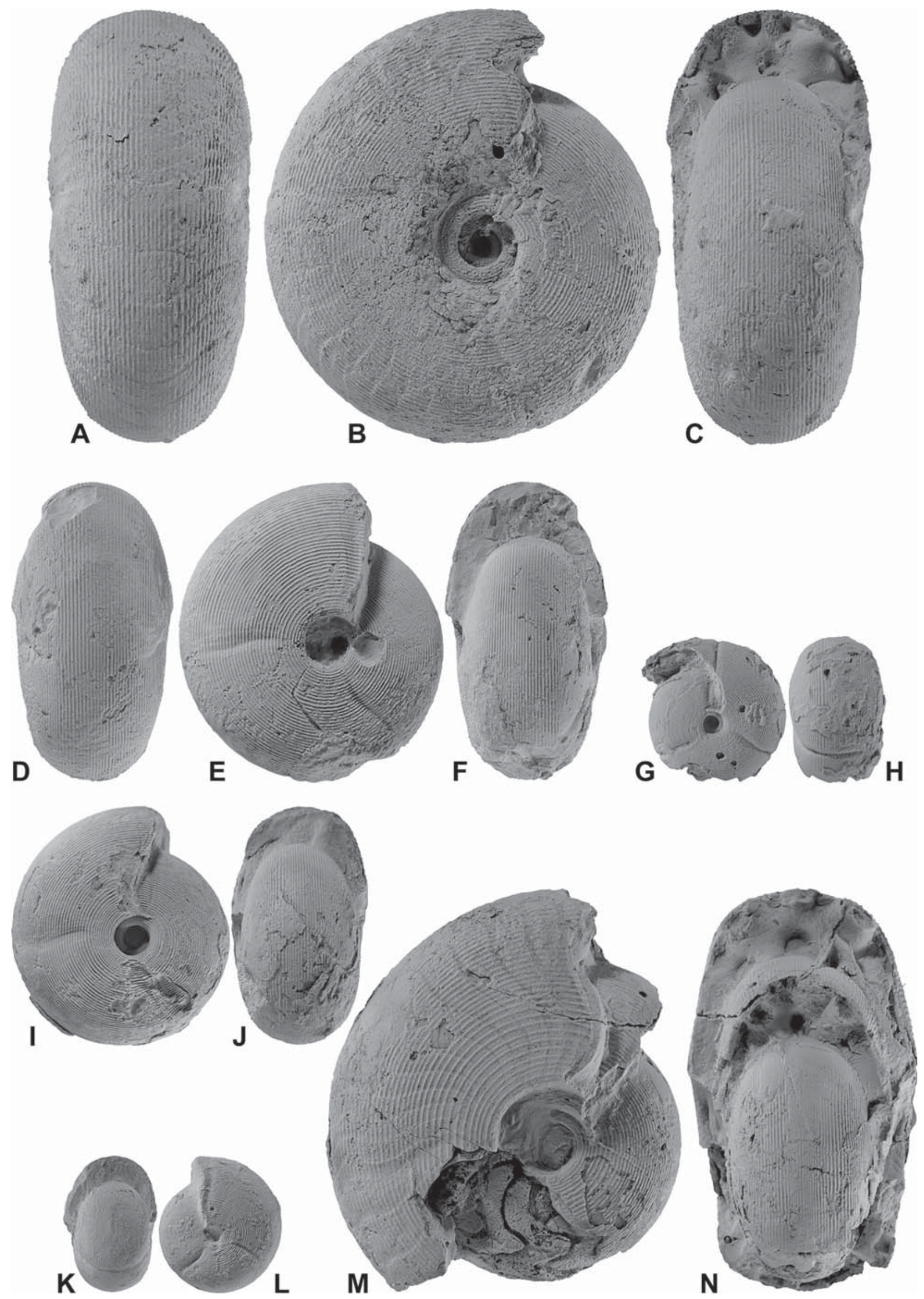

Fig. 39. Platygoniatites rhanemensis n. sp. from Horizon GI-4 of the Gara el Itima; all $\times 1$. A-C - paratype MB.C.9079.6; D-F - paratype MB.C.9079.13. G, H - paratype MB.C.9079.14; I, J - paratype MB.C.9079.8; K, L - paratype MB.C.9079.9; M, N - paratype MB.C.9079.15. 
tively. Both specimens possess shallow shell constrictions that are restricted to the flanks. They follow the growth line course and are arranged in spaces of $90^{\circ}$. Both specimens differ from specimen MB.C.9079.5 in the more V-shaped ventral sinus; particularly holotype MB.C.9079.1 has a chevron-shaped ventral sinus. Both specimens display approximately 85 regularly spaced spiral lines. The conspicuous Runzelschicht is preserved in some of the large specimens when the last volution is removed (Fig. 40). It is restricted to the flanks of the dorsal whorl zone.

Intermediate stages as displayed in specimens MB.C.9079.7 (47 mm dm; Fig. 38G, H) and MB.C.9079.8 (42 mm dm; Fig. 39I, J) have also 85-90 spiral lines and finer growth lines with rursiradiate course. In this stage, however, lateral projections and ventral sinus are much less prominent. Both specimens possess rather weak shell constrictions, best visible in the midflank area and becoming much weaker towards the venter and the umbilical margin.

The small specimen MB.C.9079.9 has, at 20-24 mm dm, a similar ornament, but the growth lines extend almost linear with only weak projections and a very shallow external sinus across flanks and venter. Three constrictions are present; they are deepest on the flanks, but continue across the venter (Fig. 39K, L).

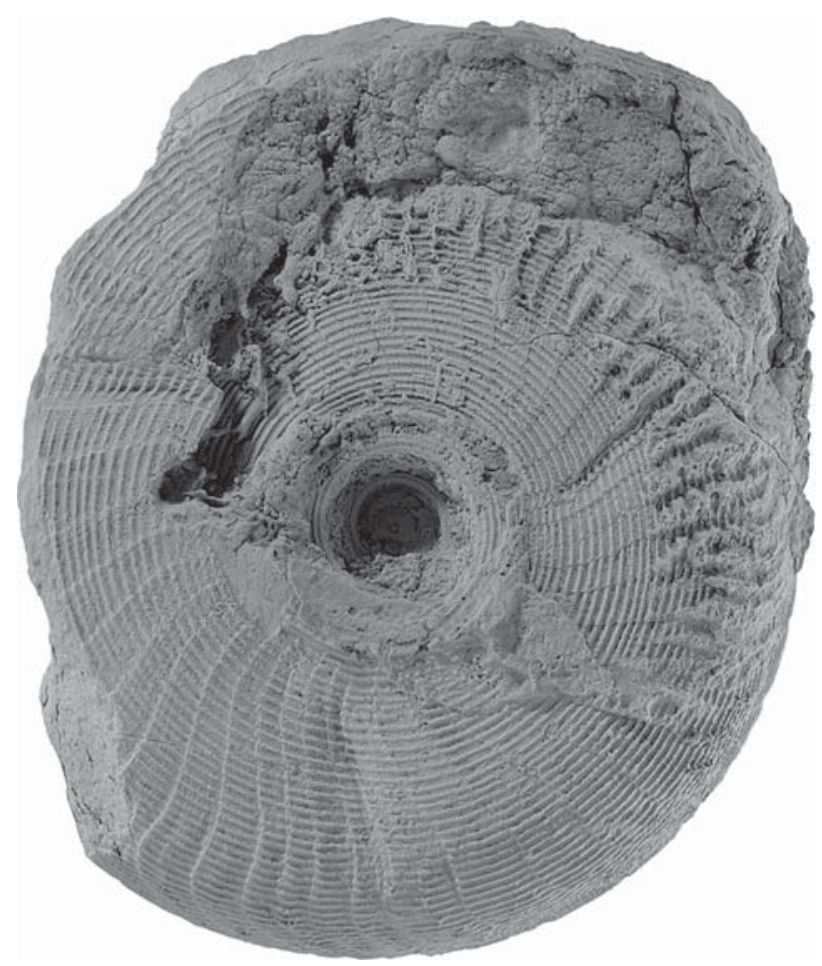

Fig. 40. Platygoniatites rhanemensis n. sp. from Horizon GI-4 of the Gara el Itima; paratype MB.C.9079.16; $\times 1$. Showing conspicuous Runzelschicht (wrinkle layer) on the flanks in the dorsal whorl zone.
A specimen intermediate in size (paratype MB.C.9079.10) shows, at $12 \mathrm{~mm}$ whorl height (corresponding to appr. $25 \mathrm{~mm} \mathrm{dm}$ ), a Y-shaped external lobe with two symmetric lanceolate prongs. The width of the external lobe is 0.81 of the depth, and the median saddle is raised 0.57 of the E lobe depth. The symmetric ventrolateral saddle is tectiform and subacute, and the adventive lobe is narrow and lanceolate. The dorsolateral saddle is higher than the ventrolateral saddle (Fig. 41E).

Paratype MB.C.9051.2 allows the study of the adult suture line at $72 \mathrm{~mm}$ conch diameter (Fig. 41F). The external lobe is widely V-shaped in this stage with sinuous and strongly diverging flanks. It has a width/depth ratio of 0.90 , and a median saddle of almost half the external lobe depth is present. A tectiform ventrolateral saddle with blunt top follows, and the asymmetric adventive lobe is slightly pouched. It is only a little wider than half of the external lobe.

Discussion. The new species can be regarded as one of the earliest representatives of the genus and the family Delepinoceratidae, displaying some affinities to species of the genus Dombarites, such as D. granofalcatus (Kullmann, 1961). It is characterised by a rather simple suture line that, in contrast to species such as Platygoniatites molaris Ruzhencev, 1956 and P. omniliratus Ruzhencev \& Bogoslovskaya, 1971, has a still comparatively narrow external lobe with a relatively low median saddle. Furthermore, it has a thicker conch than the two mentioned species.

Superfamily Neoglyphioceratoidea Plummer \& Scott, 1937

Family Ferganoceratidae Ruzhencev, 1960

\section{Ferganoceras Librovitch, 1957}

Type species. Ferganoceras elegans Librovitch, 1957.

\section{Ferganoceras torridum n. sp.}

Fig. 42

1961 Girtyoceras bisinum - Pareyn: 118, pl. 10: figs 12, 13.

Derivation of name. After the Latin torridus $=$ dried out, because of the desert in which the species was found.

Holotype. Specimen MB.C.9071 (coll. Aboussalam and Becker 2004); figured here in Fig. 42.

Type locality and horizon. Gara el Itima, southeastern Anti-Atlas, Morocco; Horizon GI-6 (middle Hamou-Rhanem Formation), probably latest Viséan. 

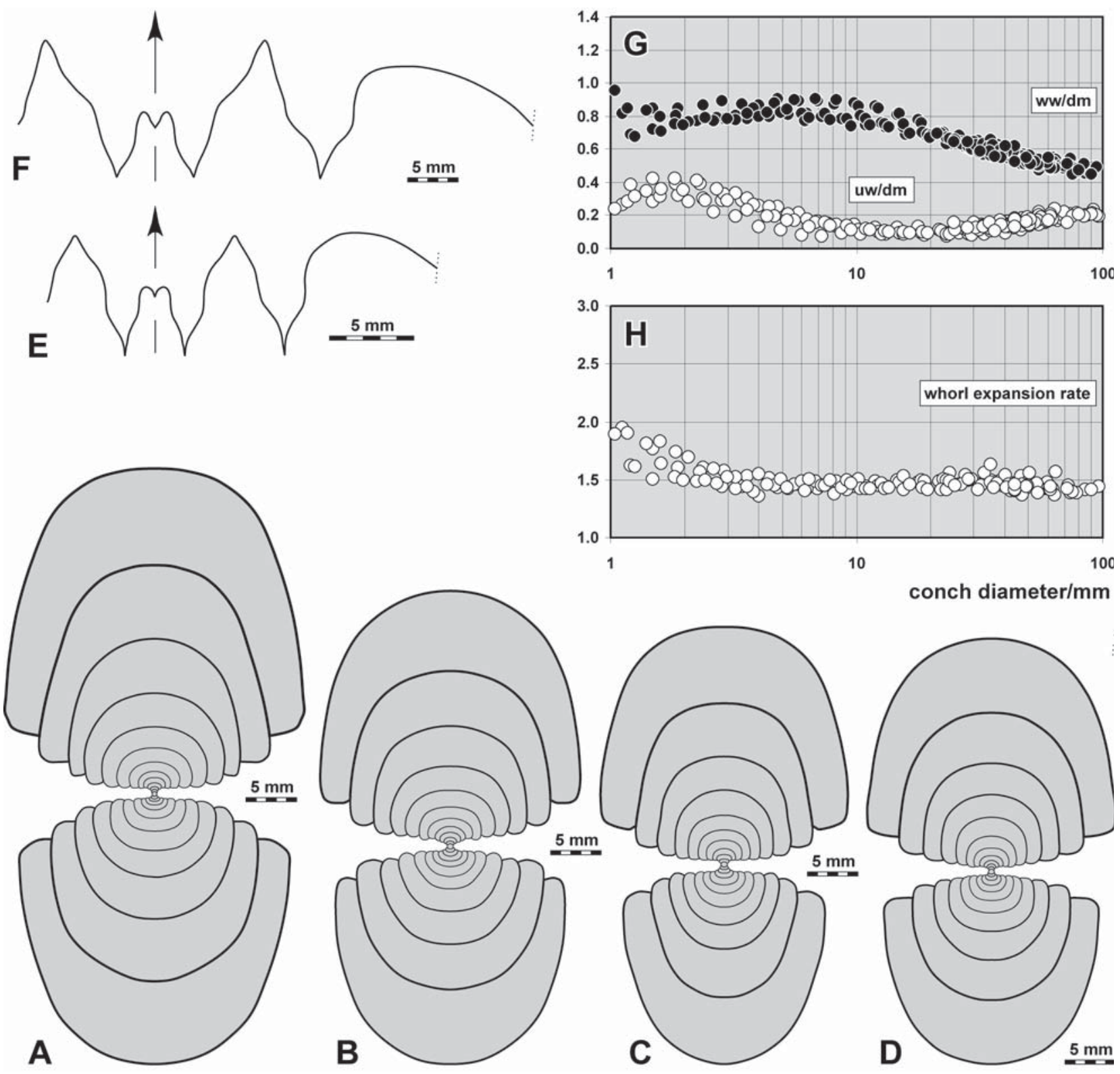

Fig. 41. Platygoniatites rhanemensis n. sp. from Horizon GI-4 of the Gara el Itima. A - Cross section, paratype MB.C.9079.2; $\times 1,5 ; \mathbf{B}-$ Cross section, paratype MB.C.9051.1; $\times 1,5 ; \mathbf{C}-$ Cross section, paratype MB.C.9079.3; $\times 1,5 ; \mathbf{D}-$ Cross section, paratype MB.C.9079.4; $\times 1,5 ; \mathbf{E}-$ Suture line (reversed), paratype MB.C.9079.10, at $11.9 \mathrm{~mm}$ wh; $\times 2.5$; $\mathbf{F}-$ Suture line (reversed), paratype MB.C. 9051.2 , at $72.3 \mathrm{~mm} \mathrm{dm}, 36.2 \mathrm{~mm}$ ww, $31.4 \mathrm{~mm}$ wh; $\times 1,5 ; \mathbf{G}$ - Ontogenetic development of the whorl width index $(\mathrm{ww} / \mathrm{dm})$ and umbilical width index $(\mathrm{uw} / \mathrm{dm}) ; \mathbf{H}-$ Ontogenetic development of the whorl expansion rate (WER).

Material. Only the holotype.

Diagnosis. Species of Ferganoceras with discoidal conch $(\mathrm{ww} / \mathrm{dm}=0.40)$ and moderately narrow umbilicus (uw/ $\mathrm{dm}=0.25)$. Ornament with 55 course spiral lines on flanks and venter. Five shell constrictions per whorl.

Description. The single specimen MB.C.9071 is strongly weathered, but shows some details of the conch shape and ornament. It has $30 \mathrm{~mm}$ conch diameter and is discoidal $(\mathrm{ww} / \mathrm{dm}=0.38)$ with a moderately narrow umbilicus (uw/ $\mathrm{dm}=0.24$ ). The flanks stand almost parallel and are bordered by a sharp ventrolateral groove. The venter is slightly flattened. Flanks and venter are ornamented with 55 spiral lines; growth lines are barely visible in the specimen. The last volution has five constrictions that run with a lateral sinus across the flanks and bend forward to

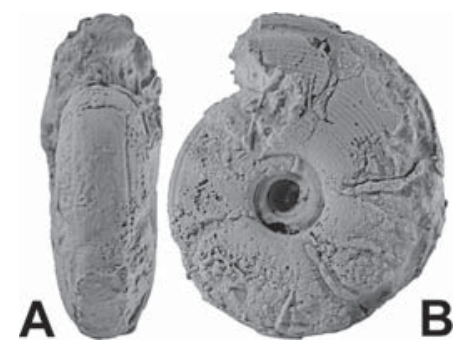

Fig. 42. Ferganoceras torridum n. sp. from Horizon GI-6 of the Gara el Itima; × 1. A, B - holotype MB.C.9071. 
a prominent ventrolateral salient. On the venter they form a shallow sinus.

Discussion. Despite the fact that only one specimen is available, it is described as a new species. For the suture line, the illustration of a specimen from Ksar el Azoudj (northwestern Algeria) by Pareyn (1961, Fig. 11D) can be used. The specimen has much coarser spiral lines than the two Uralian species $F$. elegans Librovitch, 1957 and F. gracile Ruzhencev \& Bogoslovskaya, 1971, which possess about 70-80 spiral lines. $F$. bisinum (Delépine, 1935) is only known from crushed specimens from the Pyrenees; it has also much finer spiral lines (more than 80 ) and obviously a much narrower umbilicus.

Superfamily Prolecanitoidea de Hyatt, 1884 Family Prolecanitidae Hyatt, 1884

\section{Prolecanites Mojsisovics, 1882}

Type species. Prolecanites mojsisovicsi Miller, 1938 [= Goniatites mixolobus Sandberger and Sandberger, 1851 (non Phillips, 1836)]

\section{Prolecanites maeandricus n. sp.}

Figs 43, 44

Derivation of name. After the Latin Maeandros, because of the strongly meandering suture line.

Holotype. Specimen MB.C.9085.1 (coll. Ebbighausen and Korn 2004); figured here in Fig. 43.

Type locality and horizon. Gara el Itima, southeastern Anti-Atlas, Morocco; Horizon GI-1 (Zrigat Formation), probably early part of the Late Viséan.

Material. 9 fragmentary specimens between 40 and $50 \mathrm{~mm}$ conch diameter.

Diagnosis. Species of Prolecanites with thinly discoidal conch $(w w / d m=0.35)$; umbilicus moderately wide (uw/ $\mathrm{dm}=0.45$ ). Whorl cross section slightly compressed, flanks and venter broadly rounded. Ornament with strengthened growth lines. Suture line with deep, bottle-shaped external

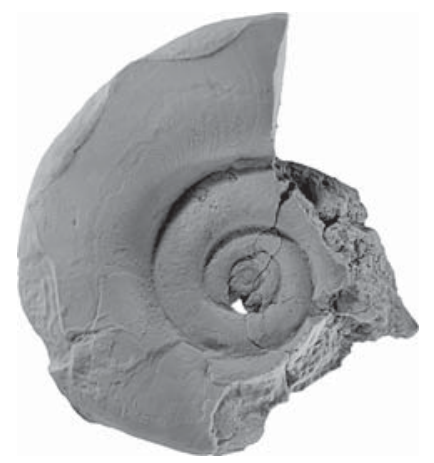

Fig. 43. Prolecanites maeandricus n. sp. from Horizon GI-1 of the Gara el Itima; $\times 1$. holotype MB.C.9085.1. lobe, pouched and pointed adventive lobe, deep, pouched and acute first lateral lobe, and pouched second lateral lobe.

Description. Holotype MB.C.9085.1 is a somewhat corroded specimen, but displays a number of characters. The serpenticonic conch has, at $33 \mathrm{~mm}$ conch diameter, whorls that embrace the preceding only to a minor degree. The whorls have an almost circular cross section, but the flanks are slightly flattened. The umbilicus has 0.45 of the conch diameter. Remains of the shell are preserved in the specimen; they show biconvex growth lines that are rather coarse on the umbilical wall, where they project forward.

Two specimens of approximately $30-33 \mathrm{~mm}$ $\mathrm{dm}$ display very similar suture lines (Fig. 44A, B). In paratype MB.C.9085.2 is the entire suture line preserved; it has a strongly pouched external lobe, followed by a narrower ventrolateral saddle, a slightly asymmetric and less pouched adventive lobe, and two further pouched lobes on the flank. Of these is the first lateral lobe the deepest of all lobes, it is strongly pouched. Two small V-shaped lobes occur on both sides of the umbilical seem, and the internal lobe is narrow and lanceolate. Close septal spacing in the midflank area causes a nesting of the suture lines, particularly of the first lateral lobe. The suture line of holotype MB.C.9085.1 principally resembles the paratype; differences are mainly in the proportions detectable.

Discussion. Prolecanites maeandricus belongs to the earlier species of the genus, indicated by the very small umbilical lobe and a less deep external lobe. Comparative are P. serpentinus (Phillips, 1836), P. hesteri Moore, 1952, P. discoides

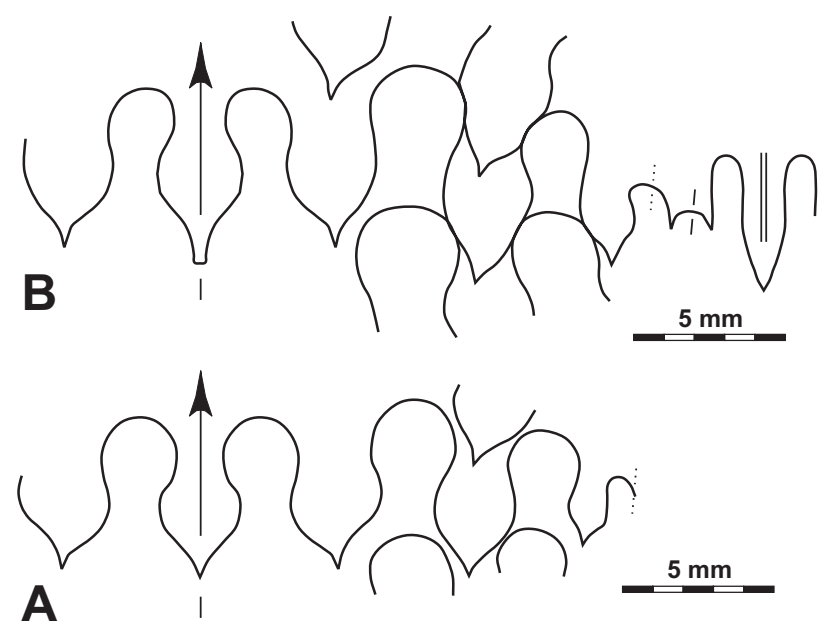

Fig. 44. Prolecanites maeandricus n. sp. from Horizon GI-1 of the Gara el Itima. A - Suture line, holotype MB.C.9085.1, at $33.1 \mathrm{~mm} \mathrm{dm}, 10.5 \mathrm{~mm}$ ww, $11.2 \mathrm{~mm}$ wh; $\times 3$; B - Suture line, paratype MB.C. 9085.2 , at $11.1 \mathrm{~mm}$ ww, $12.2 \mathrm{~mm}$ wh; $\times 3$. 
Foord \& Crick, 1897, and P. kiaensis Ruzhencev, 1966, but the main differences are as follows: P. serpentinus and P.hesteri possess wider, less pouched adventive and lateral lobes, $P$. discoides has lobes that are much less pouched and more rounded at the base, and P. kiaensis has only rounded lobes.

\section{Prolecanites mapesi n. sp.}

Figs 45, 46

Derivation of name. After Royal H. Mapes (Athens, Ohio), to acknowledge his contribution to Carboniferous palaeontology.

Holotype. Specimen MB.C.9080.1 (coll. Ebbighausen and Korn 2004); figured here in Fig. 45A, B.

Type locality and horizon. Gara el Itima, southeastern Anti-Atlas, Morocco; Horizon GI-4 (basal Hamou-Rhanem Formation), probably latest Viséan.

Material. 139 specimens between 15 and $54 \mathrm{~mm}$ conch diameter, of which one third are fragments.

Diagnosis. Species of Prolecanites with thinly discoidal conch (ww/dm 0.22-0.33) in growth stages larger than $10 \mathrm{~mm} \mathrm{dm}$; umbilicus moderately wide to wide (uw/dm $0.38-0.48)$. Whorl cross section compressed, flanks and venter rounded. Ornament smooth, occasionally with strengthened growth lines. Suture line with deep, bottle-shaped external lobe, pouched and pointed adventive lobe, deep and acute first lateral lobe, and lanceolate second lateral lobe.

Description. The conch has a similar shape in all growth stages (Fig. 46D-F). Between 15 and $54 \mathrm{~mm}$ conch diameter, there is a barely visible trend towards more compressed forms, the ww/ $\mathrm{dm}$ ratio is reduced from 0.30 to 0.25 in this interval. The relative umbilical width remains stable (uw/dm 0.40-0.45). It is only the aperture that changes significantly; the whorl expansion rate increases from 2.00 at $20 \mathrm{~mm}$ dm to 2.25 at $40 \mathrm{~mm} \mathrm{dm}$.

The two cross sections MB.C.9080.2 and MB.C.9080.3 display the slight ontogenetic changes, which are best visible in the trend towards more compressed adult whorls (Fig. 46A, B). Up to $14 \mathrm{~mm}$ conch diameter, the whorls are still almost circular in their section, but later in ontogeny, the ww/wh ratio decreases slowly. All stages show a rounded umbilical wall.

All specimens display an almost smooth shell, and ornament is only rarely visible. Holotype MB.C. 9080.1 shows, at $40 \mathrm{~mm} \mathrm{dm}$, periodically strengthened growth lines that are best visible on the flanks (Fig. 45A, B). They run biconvex with a rather prominent dorsolateral projection on the inner flank. The smaller paratype MB.C.9080.4 (36 mm dm) confirms this.

In the suture line of paratype MB.C.9080.5 (appr. $25 \mathrm{~mm} \mathrm{dm}$ ), four lobes can be counted on the flanks. Of these, the adventive lobe is the widest; it is strongly pouched and pointed at the base. The deepest lobe is the first lateral lobe, it is narrower than the adventive lobe and also strongly pouched and acute. The second lateral lobe is lanceolate, and the third lateral lobe Vshaped and rounded. The external lobe is narrow, pouched, and possesses an elongate base. It is much deeper than the adventive lobe (Fig. 46C).

Discussion. Approximately 20 species of the genus Prolecanites are known so far. All share a very similar conch morphology, and a revision of the group is required. At the moment, it is not clear how many of the species are valid.

The new species differs particularly in the suture line from other time-equivalent species from the Prototethian realm. P. primitivus (Kullmann, 1963) from the Cantabrian Mountains of Spain and P. librovitchi (Ruzhencev, 1947) from the South Urals possess a less pouched, more rounded adventive lobe. P. dombarensis Librovitch, 1975 and P. lenticularis Wang, 1983 are in-
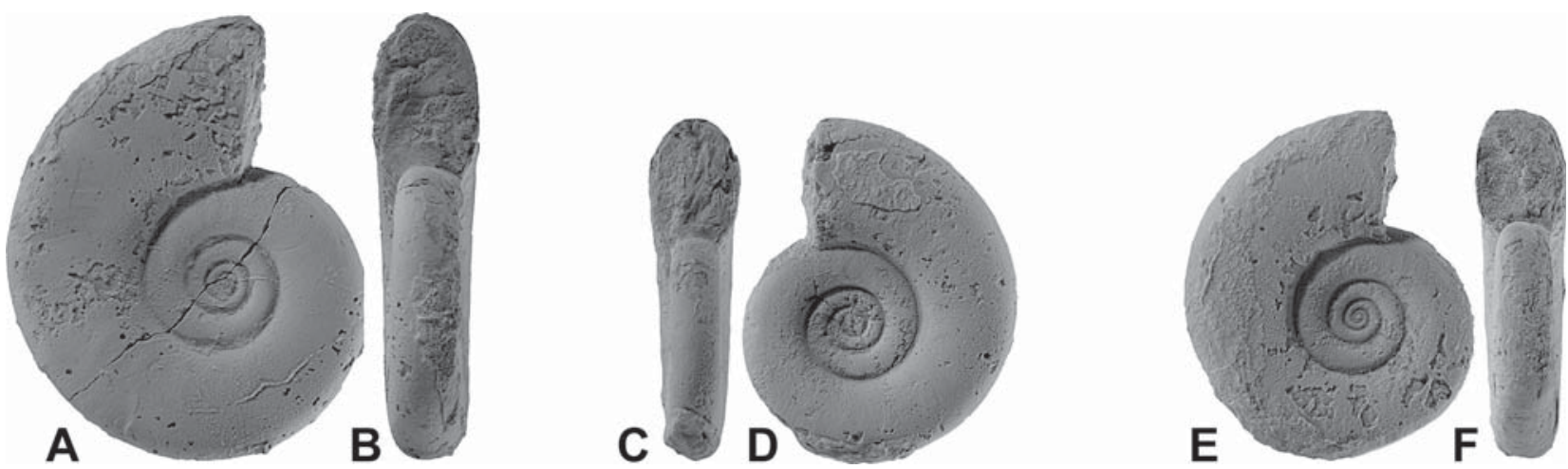

Fig. 45. Prolecanites mapesi n. sp. from Horizon GI-4 of the Gara el Itima; all $\times 1$. A, B - holotype MB.C.9080.1; C, D paratype MB.C.9080.4; E, F - paratype MB.C.9080.6. 

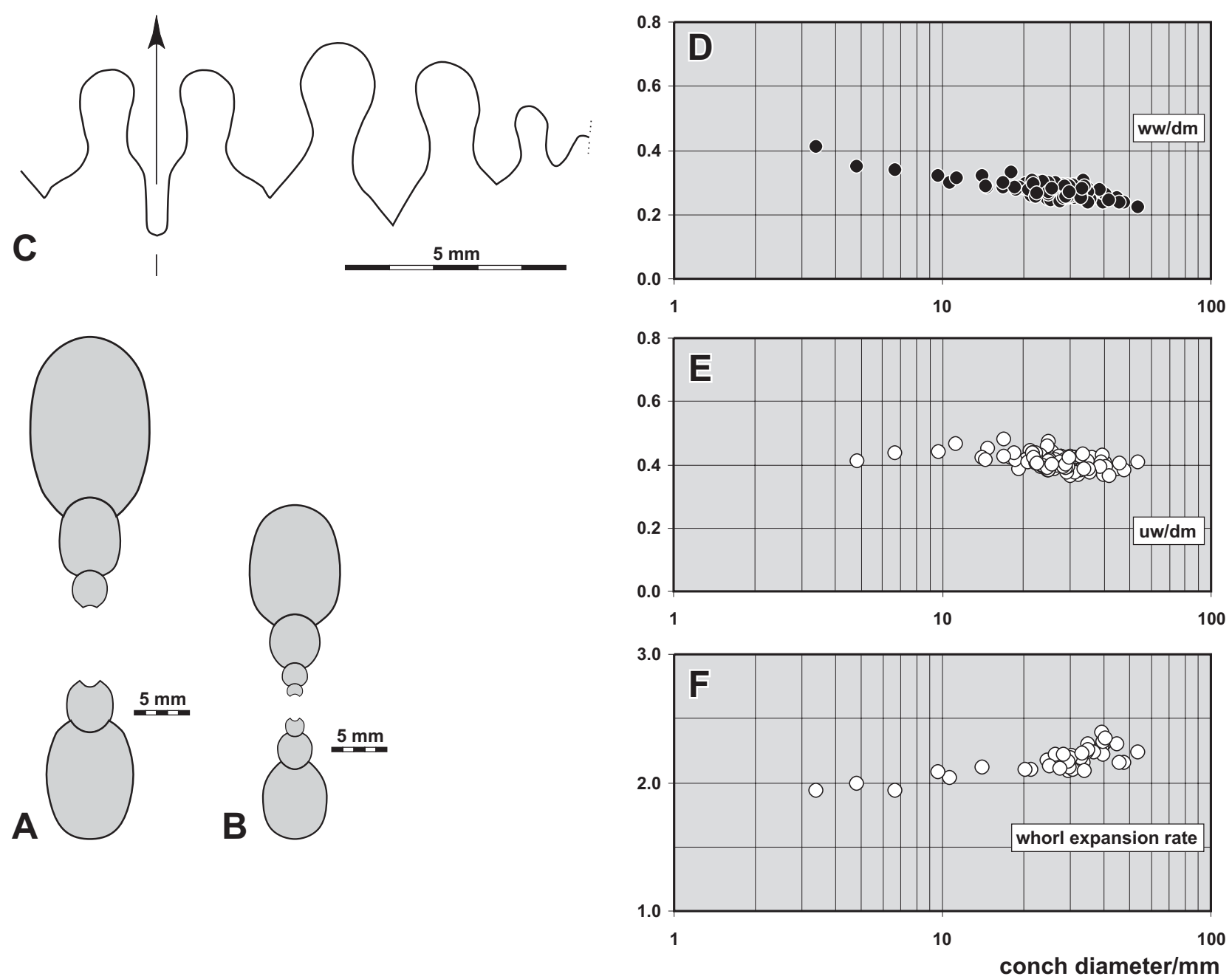

Fig. 46. Prolecanites mapesi n. sp. from Horizon GI-4 of the Gara el Itima. A - Cross section, paratype MB.C.9080.2; × 1,5; B - Cross section, paratype MB.C.9080.3; × 1,5; C - Suture line, paratype MB.C.9080.5, at $7.1 \mathrm{~mm}$ ww, $9.2 \mathrm{~mm} w \mathrm{wh} \times 6$; D Ontogenetic development of the whorl width index (ww/dm); E - Ontogenetic development of the umbilical width index (uw/ $\mathrm{dm}) ; \mathbf{F}$ - Ontogenetic development of the whorl expansion rate (WER).

sufficiently described, but appear to possess a thinner conch. P. nilkaensis Ruan, 1991 from Xinjiang is stratigraphically much younger (probably Kinderscoutian), but this species may be represent a juvenile Dombarocanites. It has rounded lobes on the flank and a short external lobe.

The stratigraphically older species of Prolecanites, such as P. serpentinus (Phillips, 1836), of which P. mixolobus (Phillips, 1836), and P. mojsisovicsi Miller, 1938 are synonyms, appear to be more similar to P. mapesi. The shape of the lobes on the flank are closely resembling, and the general conch morphology resembles the new species. The main difference is the shape of the external lobe that is longer in P.mapesi. This difference distinguishes the new species also from other species, such as $P$. discoides Foord \& Crick, 1897, P. hesteri Moore, 1952, and P. kiaensis Ruzhencev, 1966.

\section{Family Daraelitidae Tschernow, 1907}

\section{Epicanites Schindewolf, 1926}

Type species. Paraprolecanites Sandbergeri Schmidt, 1925 [non Karpinsky, 1889].

\section{Epicanites hamianensis n. sp.}

Figs 47, 48

Derivation of name. After the Oued Hamiane, where the new species was discovered.

Holotype. Specimen MB.C.9075.1 (coll. Ebbighausen and Korn 2004); figured here in Fig. 47A, B.

Type locality and horizon. Gara el Itima, southeastern Anti-Atlas, Morocco; Horizon GI-4 (basal Hamou-Rhanem Formation), probably latest Viséan.

Material. 190 specimens between 20 and $77 \mathrm{~mm}$ conch diameter, half of them are fragments; all except for one (Horizon GI-5) from Horizon GI-4. 
Diagnosis. Species of Epicanites with discoidal conch (ww/ $\mathrm{dm} 0.30-0.40)$ in all growth stages; umbilicus moderately wide (uw/dm 0.40 at $10 \mathrm{~mm} \mathrm{dm}, 0.30$ at $60 \mathrm{~mm} \mathrm{dm}$ ). Whorl cross section compressed, flanks and venter rounded. Shell almost smooth, with strengthened growth lines on the umbilical wall in large specimens. Suture line with pouched external lobe, pouched and bulb-shaped adventive lobe and first lateral lobe, and tongue-shaped second lateral lobe.

Description. Ontogenetic changes are minor in this species, and the conch form has similar proportions throughout ontogeny (Fig. 48D-F). The conch is discoidal in all stages with a ww/dm ratio of 0.32 to 0.40 . The umbilical width index (uw/dm) allows the separation of two growth stages, i.e., a juvenile stage up to $16 \mathrm{~mm}$ conch diameter, in which the umbilical width is 0.40 of the conch diameter, and a later stage in which this ratio is reduced to 0.30 . More remarkable ontogenetic changes can be seen in the whorl expansion rate. Beginning from 2.00 in early ontogeny, there is a rather constant increase to a maximum of 2.75 in late ontogeny at $75 \mathrm{~mm}$ conch diameter.

Paratype MB.C.9054.1 shows the cross section between 2 and $57 \mathrm{~mm}$ conch diameter (Fig. 48B). Up to $15 \mathrm{~mm}$ conch diameter, all whorls have a regularly compressed oval outline. The last 1.5 whorls display a slight modification with slightly flattened parallel flanks. There is some variability in the flattening of the flanks in adult conchs; some specimens such as MB.C.9075.2 display rounded but well-defined umbilical and ventro- lateral edges, while in others (paratype MB.C.9075.3, holotype MB.C.9075.1) the flanks are not bordered from the umbilical wall and the venter.

Preadult specimens such as MB.C.9075.4 (35 mm dm) and MB.C.9075.5 (44 mm dm) appear to be completely smooth (Fig. 47C, D), but this can be caused by aeolian erosion in the desert. The ornament is better preserved in the adult paratypes MB.C.9075.3 and MB.C.9075.2 $(60 \mathrm{~mm} \mathrm{dm})$, where fine growth lines are visible on the flanks, where they run with weakly biconvex course and form a shallow ventrolateral projection. These growth lines are much coarser on the umbilical wall where they show a prominent projection.

In the suture line of paratype MB.C.9075.6, at $12.5 \mathrm{~mm}$ whorl width, a strongly pouched external lobe with a median saddle of one third of the lobe depth can be recognised. On the flank follow the meandering other sutural elements, with bulb-shaped, broadly rounded adventive and first lateral lobes and a narrower saddle between them. No indication of a serration of the lobes can be seen (Fig. 48C).

Discussion. Ten species of Epicanites are known so far, if the genus is restricted to those forms that lack a serration of lobes. Ruzhencev \& Bogoslovskaya (1971) treated Epicanites in a wider sense, i.e., including Praedaraelites with
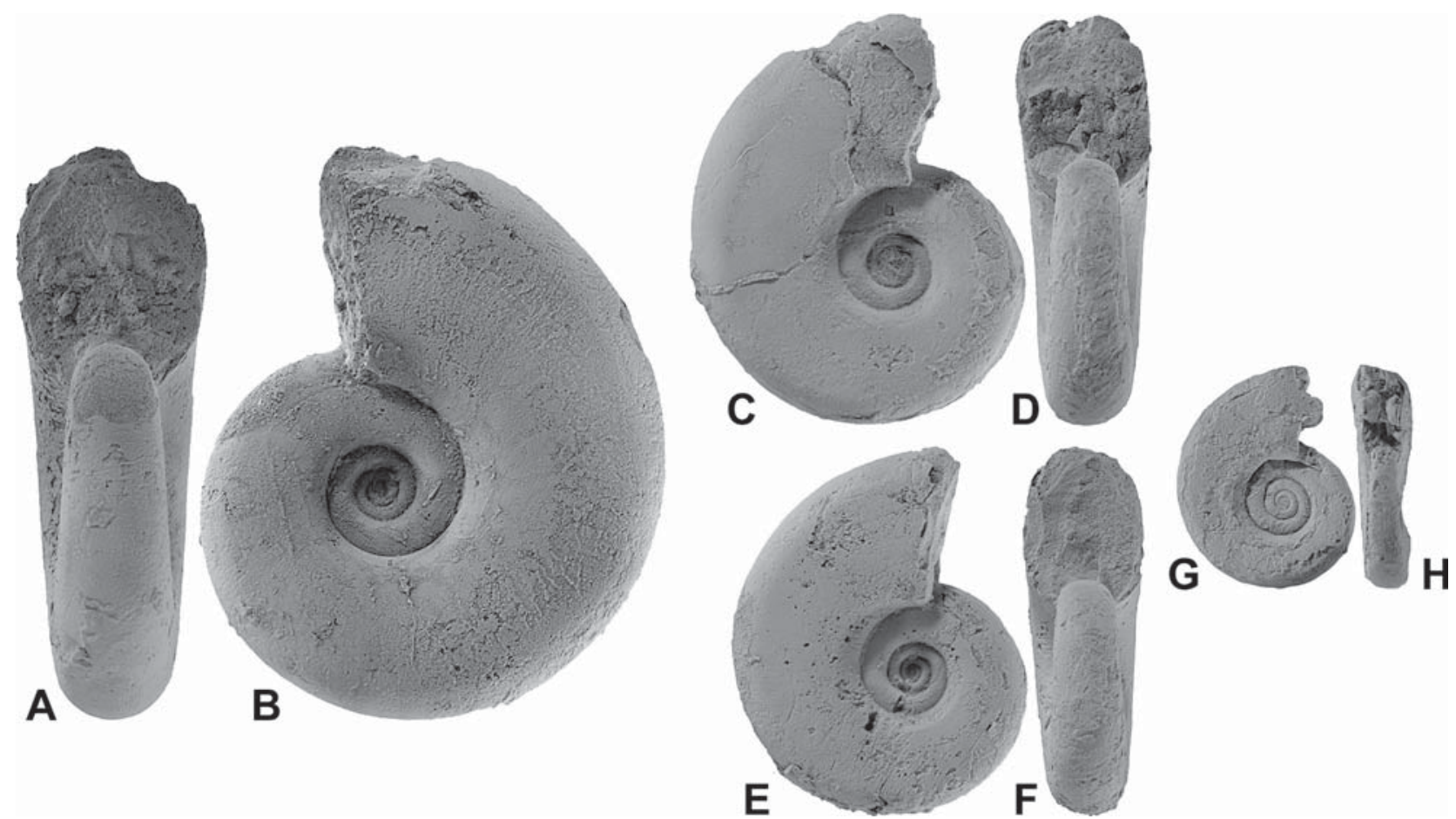

Fig. 47. Epicanites hamianensis n. sp. from Horizon GI-4 of the Gara el Itima; all $\times 1$. A, B - holotype MB.C.9075.1; C, D paratype MB.C.9075.5; E, F - paratype MB.C.9075.7; G, H - paratype MB.C.9094. 

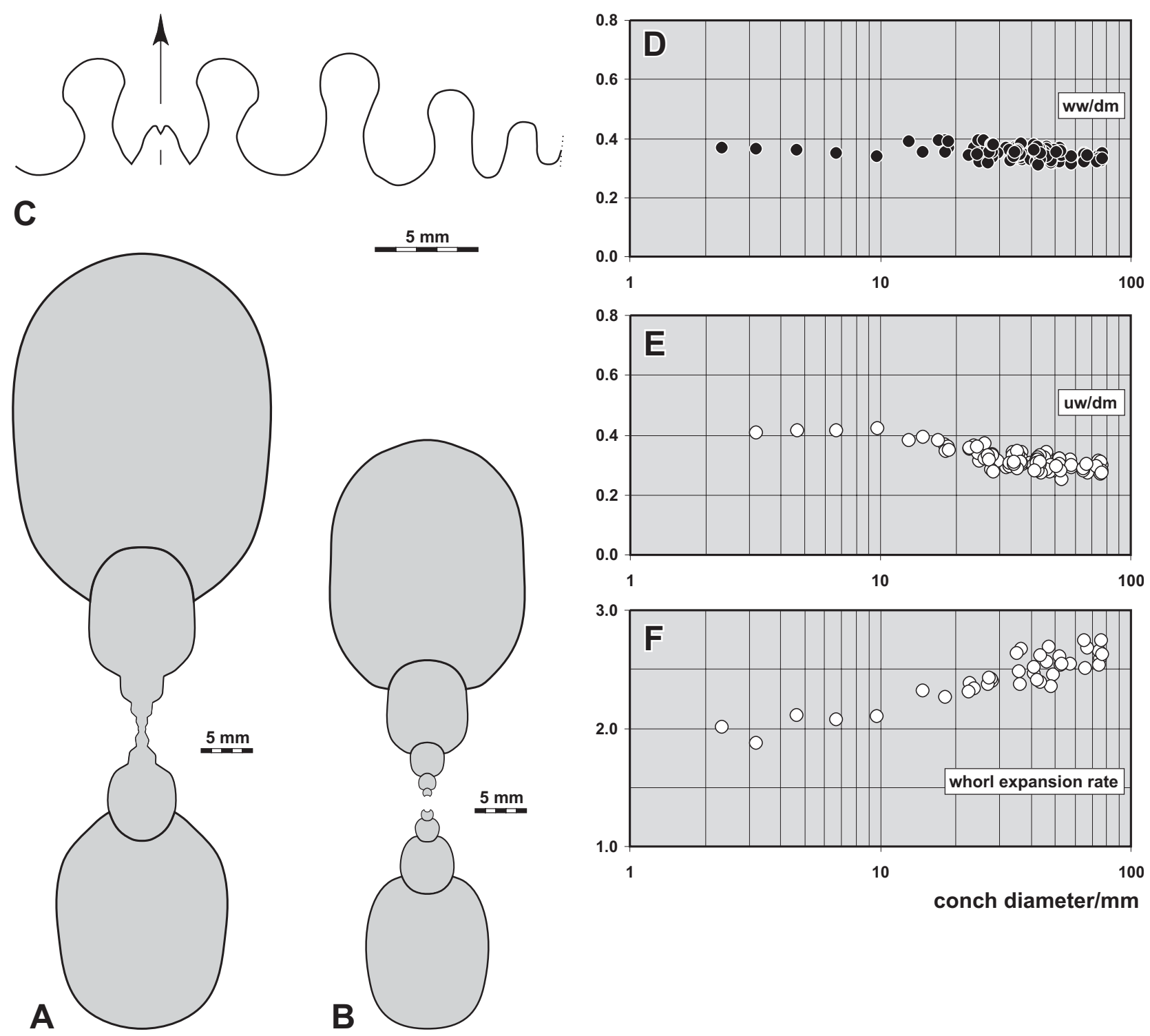

Fig. 48. Epicanites hamianensis n. sp. from Horizon GI-4 of the Gara el Itima. A - Cross section, paratype MB.C.9075.8; $\times 1,5 ; \mathbf{B}-$ Cross section, paratype MB.C. $9054.1 ; \times 1,5 ; \mathbf{C}-$ Suture line (reversed), paratype MB.C.9075.6, at $12.4 \mathrm{~mm}$ ww, $16.4 \mathrm{~mm}$ wh; $\times 3$; D - Ontogenetic development of the whorl width index (ww/dm); E - Ontogenetic development of the umbilical width index (uw/dm). F - Ontogenetic development of the whorl expansion rate (WER).

serrated lobes. The very close similarities in all other characters, such as conch shape and ornament, support this hypothesis, but it is not clear if the serration is an apomorphic or a homoplastic character. In the following, the hypothesis of an apomorphic character is supported, and Praedaraelites is regarded as a valid genus.

The type species of the genus, E. sandbergeri Schmidt, 1925, was described by the use of very small specimens from Ksar el Azoudj in northern Algeria. These specimens were maximally $12 \mathrm{~mm}$ in diameter, and therefore difficult to interpret. Pareyn (1961) figured more fragmentary preserved specimens from the vicinity of the type locality, but these came from very different horizons spanning an interval from the late Viséan into the late Serpukhovian. It is therefore questionable that all belong to the same species. These individuals appear to be more widely umbilicate than Epicanites hamianensis n. sp. E. dangeardi Pareyn, 1961 from the late Serpukhovian is also based on a small $(13.5 \mathrm{~mm} \mathrm{dm})$, but more complete specimen; it differs from the new species by an additional fifth lobe on the flank.

E. loeblichi Miller \& Furnish, 1940 from the Caney Shale of Oklahoma and E.magmus Sheng, 1983 from late Viséan rocks of Tibet are based on small specimens that can hardly be compared with the large individuals of the new species. The Cantabrian species E. discoidalis Kullmann, 1963 and E. divergens Kullmann, 1963 differ in the conch shape form: E. discoidalis has 
a subquadrate whorl cross section, and E. divergens has a narrower umbilicus (uw/dm 0.30 at $23 \mathrm{~mm} \mathrm{dm}$ ). The published suture figures of these two species show rounded prongs of the external lobe.

Superfamily Medlicottioidea Karpinsky, 1889 Family Pronoritidae Frech, 1901

\section{Megapronorites Ruzhencev, 1949}

Type species. Megapronorites sakmarensis Ruzhencev, 1949.

\section{Megapronorites itimensis n. sp.}

Figs 49, 50

Derivation of name. After the Gara el Itima, where the new species was discovered.

Holotype. Specimen MB.C.9076.1 (coll. Ebbighausen and Korn 2004); figured here in Fig. 49A, B.
Type locality and horizon. Gara el Itima, southeastern Anti-Atlas, Morocco; Horizon GI-4 (basal Hamou-Rhanem Formation), probably latest Viséan.

Material. 21 specimens between 19 and $90 \mathrm{~mm}$ conch diameter, mostly fragmentary preserved.

Diagnosis. Species of Megapronorites with thinly discoidal conch at $20 \mathrm{~mm} \mathrm{dm}(\mathrm{ww} / \mathrm{dm}=0.25-0.30)$ and discoidal conch at $40-80 \mathrm{~mm} \mathrm{dm}(\mathrm{ww} / \mathrm{dm}=0.30-0.35)$. Umbilicus very wide in early stages (uw/ $/ \mathrm{dm}=0.50$ at $10 \mathrm{~mm} \mathrm{dm})$, closing during ontogeny (uw $/ \mathrm{dm}=0.15-0.20$ at $40-60 \mathrm{~mm} \mathrm{dm}$ ). Whorl cross section compressed, flanks and venter flattened; adult stage with concave venter. Shell almost smooth. Suture line with asymmetric adventive lobe and three lanceolate, pointed lobes on the flank.

Description. Ontogenetic changes are significant; cross section MB.C.9076.2 shows a serpenticonic conch up to $7 \mathrm{~mm}$ conch diameter (Fig. 50A). In later stages, the whorls become compresses and flattened. The venter is flattened at $32 \mathrm{~mm} \mathrm{dm}$, and at $50 \mathrm{~mm} \mathrm{dm}$, the umbilical wall is oblique. At this stage, the aperture is rather high, with a whorl expansion rate of 2.37.

The smallest specimen MB.C.9076.3 is unfortunately poorly preserved, but the conch shape and dimensions are visible. The flanks are flat
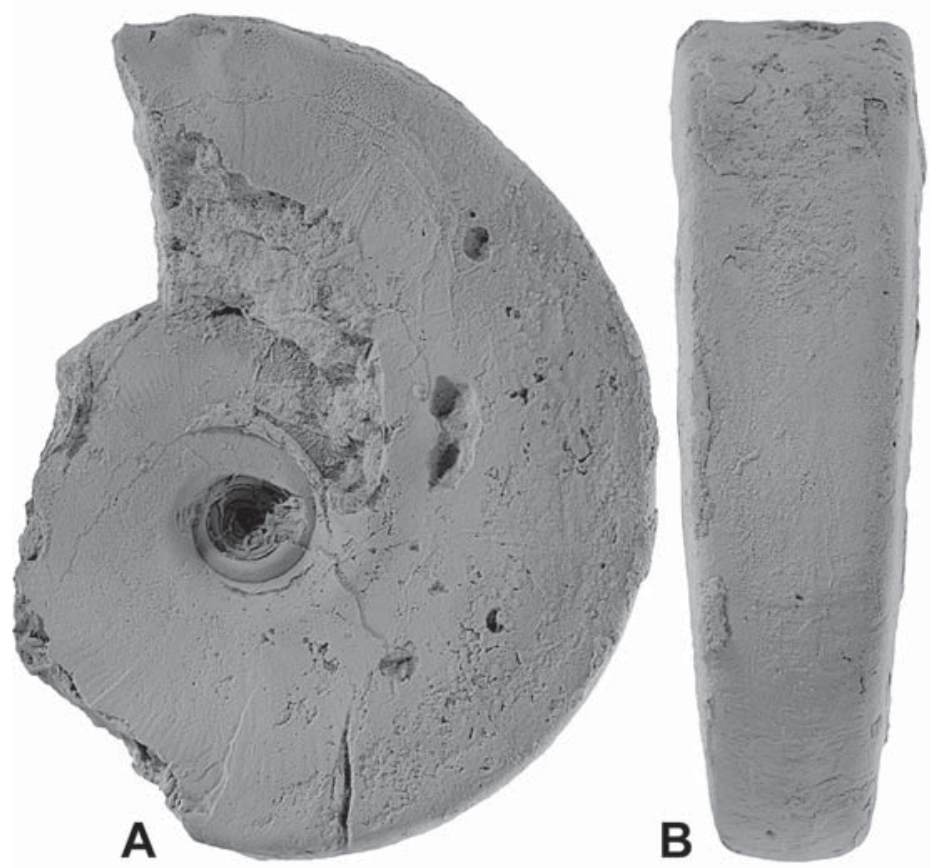

E

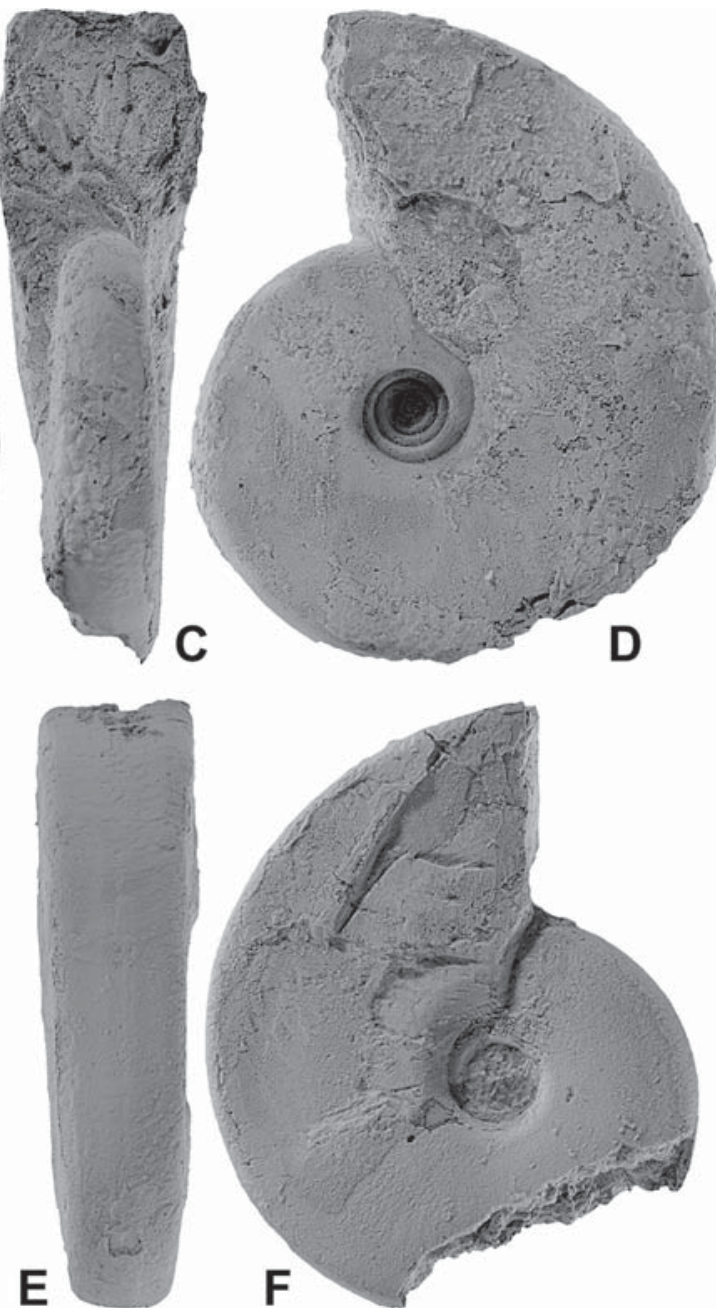

Fig. 49. Megapronorites itimensis n. sp. from Horizon GI-4 of the Gara el Itima; all $\times 1$. A, B - holotype MB.C.9076.1; C, D - paratype MB.C.9076.5; E, F - paratype MB.C.9055. 

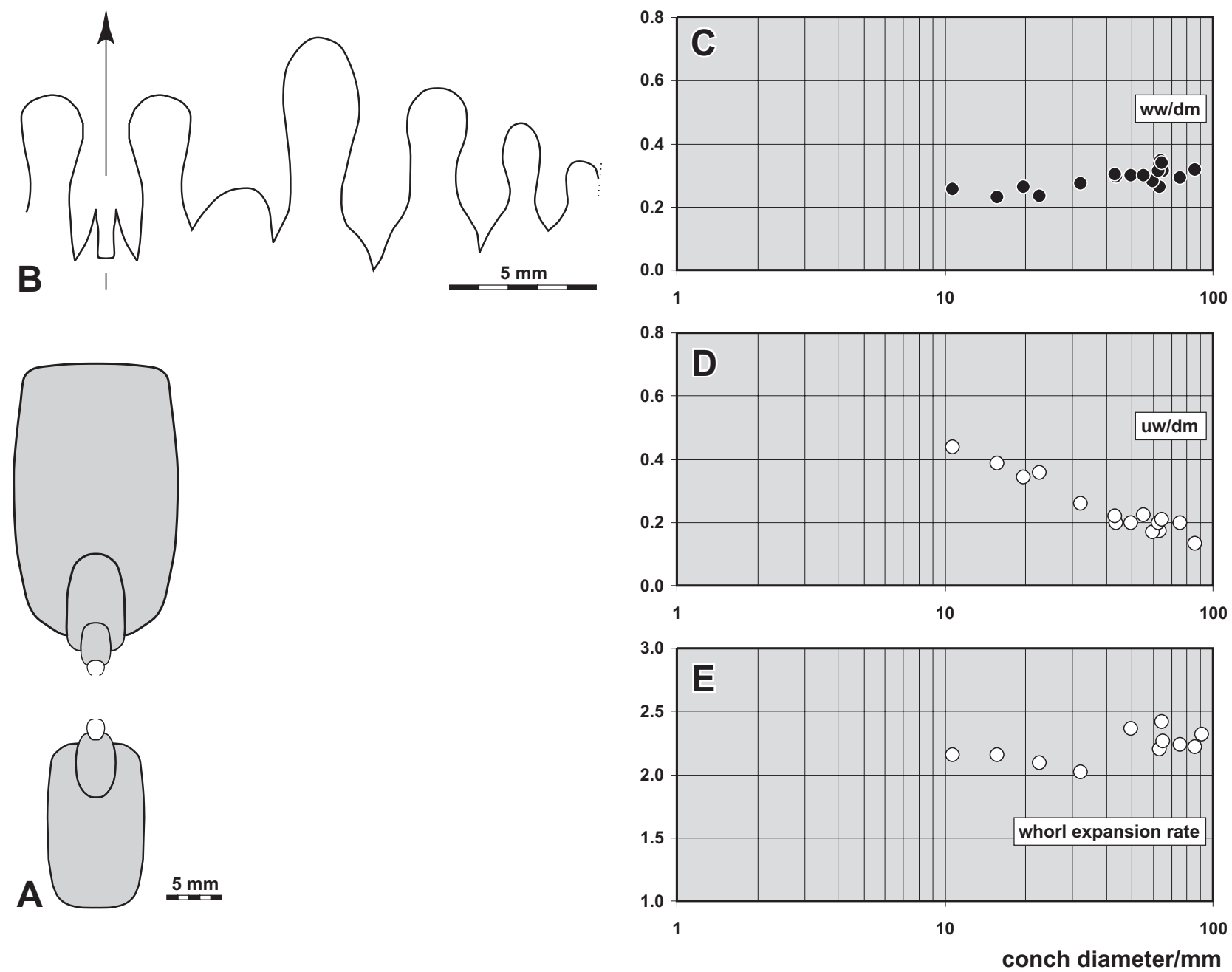

Fig. 50. Megapronorites itimensis n. sp. from Horizon GI-4 of the Gara el Itima. A - Cross section, paratype MB.C.9076.2; $\times 1,5 ; \mathbf{B}$ - Suture line (reversed), paratype MB.C.9076.4, at $35.5 \mathrm{~mm} \mathrm{dm}, 10.2 \mathrm{~mm}$ ww; $\times 4$; $\mathbf{C}$ - Ontogenetic development of the whorl width index (ww/dm); D - Ontogenetic development of the umbilical width index (uw/dm); E - Ontogenetic development of the whorl expansion rate (WER).

and stand parallel, and the venter is rounded. The umbilical margin is also rounded, and the umbilical wall is steep.

An immature pratype (MB.C.9055) of $62 \mathrm{~mm}$ conch diameter is rather well preserved and displays the transformation towards the mature morphology within one whorl (Fig. 49E, F). At the beginning of the last preserved whorl, at approximately $27 \mathrm{~mm} \mathrm{dm}$, the section resembles the small individual MB.C.9076.3, with flattened flanks and widely rounded venter. Half a whorl later, at $43 \mathrm{~mm} \mathrm{dm}$, there is a distinct ventrolateral margin that separates the slightly flattened venter from the flanks. At this stage, the umbilical wall becomes oblique. At its largest diameter, the specimen shows a completely flat venter that is bordered from the flanks by a rectangular margin. Though slightly crushed in this stage, the umbilical wall can be seen as being very shallow.

The adult stage shows further modifications of the whorl section. Holotype MB.C.9076.1 has, at
$80 \mathrm{~mm}$ conch diameter, a slightly concave venter and a very shallow, wide furrow that takes place in the outer third of the flanks (Fig. 49A, B). In this stage, the umbilicus is rather narrow (uw/dm 0.14) with an oblique wall that marks the continuation into the flanks. In specimen MB.C.9076.5, a slightly concave venter is already present at $65 \mathrm{~mm} \mathrm{dm}$.

An incomplete suture line could be drawn from paratype MB.C.9076.4 (Fig. 50B). It displays, at $35 \mathrm{~mm}$ conch diameter, the characteristic elements of the genus: a narrow and slightly pouched external lobe that is deeper than the bifid, asymmetric adventive lobe. Three narrow, pouched and pointed lobes follow on the flank, and the expected fourth is destroyed by erosion of the inner flank of the specimen.

Discussion. The type species of the genus, M. sakmarensis Ruzhencev, 1949, has a similar conch shape and suture line, but particularly the 
adult conch allows a clear distinction. M. sakmarensis has, at $100 \mathrm{~mm}$ conch diameter, a tabulate but slightly convex venter, which in the new species is concave. The ventrolateral groove is more pronounced in M. sakmarensis. A sutural difference is the subangular saddle in the adventive lobe of M. sakmarensis; in M. itimensis this is widely rounded.

\section{Acknowledgements}

We are indebted to Z. Sarah Aboussalam, Sandra Kaiser, R. Thomas Becker (all Münster), and Dieter Weyer (Berlin) for making their collections available for study. We also thank Evelin Stenzel (Berlin) for the careful preparation of a large number of specimens, Wolfgang Gerber (Tübingen) for the photography of all illustrated specimens, and Rodion Ebbighausen (Köln) for the active and successful participation in the field campaign in November, 2004. Alan Titus (Kanab), Jobst Wendt (Tübingen), and David Work (Augusta) mindfully reviewed the manuscript.

\section{References}

Arthaber, G. von 1911. Die Trias von Albanien. - Beiträge zur Paläontologie und Geologie Österreich und Ungarns 24: $169-177$.

Bisat, W. S. 1928. The Carboniferous goniatite zones of England and their continental equivalents. Compte Redue Congrès International de Stratigraphie et de Géologie du Carbonifère (Heerlen 1927), 117-133.

- 1934. The goniatites of the Beyrichoceras Zone in the north of England. - Proceedings of the Yorkshire Geological Society 22: $280-309$.

- 1950. The junction faunas of the Visean and Namurian. Transactions of the Leeds Geological Association 6: $10-26$.

Bogoslovskaya, M. F. 1966. Rod Goniatites i ego predstavateli na Yuzhnom Urale. - Paleontologicheskiy Zhurnal 1966 (1): $38-46$

Bourque, P., Madi, A. \& Mamet, B. L. 1995. A Waulsortiantype bioherm development and response to sea-level fluctuations, upper Visean of Bechar Basin, western Algeria. - Journal of Sedimentary Research, Section B: Stratigraphy and Global Studies $\mathbf{6 5}$ (1): 80-96.

Brüning, K. 1923. Beiträge zur Kenntnis des Rheinisch-westfälischen Unterkarbons, insbesondere der Goniatiten und Korallen in der stratigraphischen Stellung und Gliederung. - 1-59; Marburg.

Delépine, G. 1935. Contribution a l'étude de la faune du Dinantien des Pyrénées. Deuxieme partie. La faune de Mondette. - Bulletin de la Societé géologique de France, 5ème série 5: 171-191.

- 1941. Les goniatites du Carbonifère du Maroc et des confins Algéro-Marocains du sud (Dinantien-Westphalien). Notes et Mémoires, Service géologique, Protectorat de l'État Francais au Maroc 56: 1-111.

Destombes, J. \& Hollard, H. 1986. Tafilalt - Taouz, echelle 1:200.000. In: Fetah, S. E. M., Bensaid, M. M. \& Dahmani, M. M. (eds.): Carte Géologique du Maroc. - Notes et Mémoires du Service Géologique du Maroc 244; Rabat.

Drahovzal, J. A. \& Quinn, J. H. 1972. A new Goniatites species from the Chesterian of Arkansas. - Journal of Paleontology 46: $581-590$.

Foord, A. H. \& Crick, G. C. 1897. Catalogue of the fossil Cephalopoda in the British Museum (Natural History). Part
III. Containing the Bactritidae, and part of the suborder Ammonoidea. 303 pp., London.

Frech, F. 1901. Lethaea geognostica oder Beschreibung und Abbildung der für die Gebirgs-Formationen bezeichnendsten Versteinerungen. I. Theil. Lethaea palaeozoica. 2. Band.

Gordon, M. Jr. 1957. Missisippian Cephalopods of Northern and Eastern Alaska. - Professional Papers, U.S. Geological Survey 283: $1-61$

- 1962. Species of Goniatites in the Caney Shale of Oklahoma. - Journal of Paleontology 36: 355-357.

- 1965. Carboniferous Cephalopods of Arkansas. - Professional Papers, U.S. Geological Survey 460: 1-322.

Haan, G. de 1825. Monographia Ammoniteorum et Goniatiteorum. 168 pp., Lugduni Batavorum (Hazenberg).

Hyatt, A. 1883-1884. Genera of fossil cephalopods. - Proceedings of the Boston Society of Natural History 22: 253-338 (253-272 publ. 1883, 273-338 publ. 1884).

Karpinsky, A. P. 1889. Über die Ammoneen der ArtinskStufe und einige mit denselben verwandte carbonische Formen. - Mémoires de l'Académie Impériale des Sciences de St.-Pétersbourg, VIIe Série 37 (2): 1-104.

Korn, D. 1988. Die Goniatiten des Kulmplattenkalkes (Cephalopoda, Ammonoidea; Unterkarbon; Rheinisches Schiefergebirge). - Geologie und Paläontologie in Westfalen 11: 1-293.

- 1990. Weitere Goniatiten aus dem Ober-Visé des Rheinischen Schiefergebirges. - Geologie und Paläontologie in Westfalen 15: 11-69.

- 1996. Revision of the Late Visean goniatite stratigraphy. - Annales de la Société géologique de Belgique 117 (1): 205-212.

- 1997. The Palaeozoic ammonoids of the South Portuguese Zone. - Memórias do Instituto Geológico e Mineiro de Portugal 33: 1-132.

- 2000. Morphospace occupation of ammonoids over the Devonian-Carboniferous boundary. - Paläontologische Zeitschrift 74 (3): 247-257.

Korn, D., Bockwinkel, J., Ebbighausen, V. \& Klug, C. 2003. Palaeobiogeographic and evolutionary meaning of an early Late Tournaisian ammonoid fauna from the Tafilalt of Morocco. - Acta Palaeontologica Polonica 48 (1): 71-92.

Korn, D., Klug, C. \& Mapes, R. 1999. Viséan and Early Namurian Ammonoids from the Tafilalt (Eastern Anti-Atlas, Morocco). - Abhandlungen der Geologischen Bundesanstalt 54, North Gondwana: Mid-Paleozoic Terranes, Stratigraphy and Biota (Eds. R. Feist, J. A. Talent \& A. Daurer): 345-375.

- 2004. Cuboid Carboniferous ammonoids. - Mitteilungen aus dem Geologisch-Paläontologischen Institut der Universität Hamburg 88: 79-97.

- 2005. The Lazarus ammonoid genus Goniatites, the tetrangularly coiled Entogonites, and Early Carboniferous biogeography. - Journal of Paleontology 79 (2): 149-158.

Korn, D. \& Tilsley, J. (in press): Ammonoid assemblages from the Asbian $\mathrm{B}_{2 \mathrm{~b}}$ Subzone (Early Carboniferous) of Derbyshire, England. - Proceedings of the Yorkshire Geological Society

Kullmann, J. 1961. Die Goniatiten des Unterkarbons im Kantabrischen Gebirge (Nordspanien). I. Stratigraphie. Paläontologie der U. O. Goniatitina Hyatt. - Neues Jahrbuch für Geologie und Paläontologie, Abhandlungen 113 (3): 219-326.

- 1963a. Die Goniatiten des Unterkarbons im Kantabrischen Gebirge (Nordspanien). II. Paläontologie der U. O. Prolecanitina Miller \& Furnish. Die Altersstellung der Faunen. - Neues Jahrbuch für Geologie und Paläontologie, Abhandlungen 116 (3): 269-324.

- 1963b. Las series devónicas y del Carbonífero inferior con ammonoideos de la Cordillera Cantábrica. - Estudios Geológicos 19: 161-191,

Kullmann, J. \& Scheuch, J. 1970. Wachstums-Änderungen in der Ontogenese paläozoischer Ammonoideen. - Lethaia 3: $397-412$. 
Kusina, L. F. 1973. K revizii roda Muensteroceras. - Paleontologicheskiy Zhurnal 1973 (3): 14-25.

Librovitch, L. S. 1957. O nekotorykh novykh gruppakh goniatitov iz kamennougol'nykh otlozheniy SSSR. - Ezhegodnik Vsesoyuznogo Paleontologicheskogo Obshchestva 16: $246-272$

Madi, A., Bourque, P. \& Mamet, B. L. 1993. Waulsortiantype mound complexes, Bechar Basin, northwestern Algeria; architecture, depth-energy zonation, sequence stratigraphy and sea-level curve. In: Beauchamp, B., Embry, A. \& Glass, D. (eds.): Carboniferous to Jurassic Pangea, first international symposium; program and abstracts: 354; Calgary.

Martin, W. 1809. Petrificata Derbiensia; or, Figures and Descriptions of Petrifactions collected in Derbyshire. 28 pp., Wigan.

Miller, A. K. 1938. Devonian ammonoids of America. Geological Society of America, Special Papers 14: 262 pp.

Miller, A. K. \& Furnish, W. M. 1940. Studies on Carboniferous ammonoids: parts 1-4. - Journal of Paleontology 14: 356-377.

Moore, E. W. J. 1946. The Carboniferous Goniatite Genera Girtyoceras and Eumorphoceras. - Proceedings of the Yorkshire Geological Society 25: 387-445.

- 1950. The Genus Sudeticeras and its Distribution in Lancashire and Yorkshire. - Journal of the Manchester Geological Association 1950 (2): 31-50.

- 1952. Notes on the genera Prolecanites and Epicanites with description of two new species. - Liverpool and Manchester Geological Journal 1 (1): 71-76.

Moore, E. W. J. \& Hodson, F. 1958. Goniatites from the Upper Viséan shales of County Leitrim, Eire. - Liverpool and Manchester geological Journal 2 (1); 86-105.

Nicolaus, H.-J. 1963. Zur Stratigraphie und Fauna der crenistria-Zone im Kulm des Rheinischen Schiefergebirges. Beihefte zum Geologischen Jahrbuch 53: 1-246.

Pareyn, C. 1961. Les Massifs Carbonifères du Sahara Sud-Oranais. Tome II. Paléontologie stratigraphique. - Publications du Centre de Recherches Sahariennes, Série Géologie 1: 1-244.

Patteisky, K. 1930. Die Geologie und Fossilführung der mährisch-schlesischen Dachschiefer und Grauwackenformationen. - I-XI, 1-354, Naturwissenschaftlicher Verein Troppau.

Phillips, J. 1836. Illustrations of the geology of Yorkshire; or a description of the strata and organic remains; accompanied by a geological map, sections, and diagrams, and figures of the fossils. Part II. The Mountain Limestone District. I-XX, 1-259, London.

Plummer, F. B. \& Scott, G. 1937. Upper Paleozoic Ammonites in Texas. - In: The Geology of Texas, Vol. III, Pt. 1, University of Texas Bulletin 3701: 1-516.

Roemer, F. A. 1850. Beiträge zur geologischen Kenntnis des nordwestlichen Harzgebirges. - Palaeontographica 3: $1-69$.

Ruan Yi-ping 1991. Lower Upper Carboniferous cephalopods of Nilka, Western Xinjiang. - Acta Paleontologica Sinica 30 (2): 186-211.

Ruzhencev, V. E. 1947. Novyy rod iz semeystva Cheiloceratidae $\mathrm{v}$ namyurskikh otlozheniyakh Urala. - Doklady Akademii Nauk SSSR 57 (3): 281-284

- 1949. Sistematika i evolyutsia semeystv Pronoritidae Frech i Medlicottiidae Karpinsky. - Trudy Palentologicheskogo Instituta Akademiya Nauk SSSR 19: 1-206.

- 1950. Verkhnekamennougol'nye ammonity Urala. - Trudy Palentologicheskogo Instituta Akademiya Nauk SSSR 29: $1-223$.

- 1956. O nekotorykh novykh roday ammonoidey. - Doklady Akademii Nauk SSSR 107: 158-161.
- 1960. Printsipy sistematiki, sistema i filogeniya paleozoyskikh ammonoidey. - Trudy Paleontologicheskogo Instituta Akademiya Nauk SSSR 133: $1-331$.

- 1966. Viseyskie ammonoidei na Yuzhnom Urale. - Paleontologicheskiy Zhurnal 1966 (1): 47-59.

Ruzhencev, V. E. \& Bogoslovskaya, M. F. 1970. Reviziya nadsemeystva Goniatitaceae. - Paleontologicheskiy Zhurnal 1970 (4), 52-65.

- 1971. Namyurskiy etap v evolyutsii ammonoidey. Rannenamyurskie ammonoidei. - Trudy Paleontologicheskogo Instituta Akademiya Nauk SSSR 133: 1-382.

Sandberger, G. \& Sandberger, F. 1850-1856. Die Versteinerungen des rheinischen Schichtensystems in Nassau. Mit einer kurzgefassten Geognosie dieses Gebietes und mit steter Berücksichtigung analoger Schichten anderer Länder. XIV + 564 pp., Wiesbaden.

Sarg, J. F. 1988. Carbonate sequence stratigraphy. - In: Wilgus, C. K. Hastings, B. K., Posamentier, H., Van Wagoner, J., Ross, C. A. \& Kendall, C. G. St. C. (eds.): Sea-Level Changes - An Integrated Approach, SEPM Special Publication 42: 155-181.

Schindewolf, O. H. 1926. Beiträge zur Kenntnis der Cephalopodenfauna des oberfränkisch-ostthüringischen Unterkarbons. - Senckenbergiana 8: 63-96.

Schmidt, H. 1925. Die carbonischen Goniatiten Deutschlands. - Jahrbuch der Preußischen Geologischen Landesanstalt 45 (for 1924): 489-609.

Sebbar, A. \& Ait-Ouali, R. 1996. Dynamique de la plateforme carbonatee du Carbonifère du bassin de "BecharMezarif"; paleoenvironnements, bioconstructions. - Bulletin, Office National de la Geologie 7 (2): 229-251.

Sheng Huaibin 1983. The ammonoids of late Lower Carboniferous from Yongzhu village, Xainza district in North Xizang. - In: The Geology of the Qinghai-Xizang (Tibet) Plateau, 41-68.

Skompski, S., Paszkowski, M., Krobicki, M., Kokovin, K., Korn, D., Tomas, A. \& Wrzolek, T. 2001. Depositional setting of the Devonian/Carboniferous biohermal Bol'shaya Nadota Carbonate Complex, Subpolar Urals. Acta Geologica Polonica 51 (3), 217-235.

Sowerby, J. 1812-1814. The mineral conchology of Great Britain; or coloured figures and descriptions of those remains of testaceous animals or shells, which have been preserved at various times and depths in the earth. Vol. I, 234 pp., London.

Tschernow, A. A. 1907. Artinskiy yarus. I. ammonei basseynov Yayvy, Kos'vy i Chusovoy. Vypusk' I. Vvedenie. Obzor izsledovanoy mestnosti. Prolecanitidae. - Byelleten' Moskovskaya obshchestva ispytatelei prirody $20(3,4): 270-401$.

Wagner-Gentis, C. H. T. 1963. Lower Namurian goniatites from the Griotte limestone of the Cantabric Mountain Chain. - Notas y Comunicaciones del Instituto geologoco y Minero de España 69: 5-42.

- 1980. Goniatites from the Viséan-Namurian junction beds in Palencia, NW Spain. - Scripta Geologica 55: 1-43.

Wang Ming-qian 1983. Cephalopoda. - In: Fossil Atlas of Northwest China, Xinjiang, Volume 2: 514-533, Beijing (Geological Publishing House).

Wedekind, R. 1918. Die Genera der Palaeoammonoidea Goniatiten). Mit Ausschluß der Mimoceratidae, Glyphioceratidae und Prolecanitidae. - Paläontographica 62: 85-184.

Weyer, D. 1972. Trilobiten und Ammonoideen aus der Entogonites nasutus-Zone (Unterkarbon) des Büchenberg-Sattels (Elbingeröder Komplex, Harz). Teil I. - Geologie 21 (2): $166-184$.

Wendt, J., Kaufmann, B. \& Belka, Z. 2001. An exhumed Palaeozoic underwater scenery: the Visean mud mounds of the eastern Anti-Atlas (Morocco). - Sedimentary Geology 145: 215-233. 


\section{Appendix}

Conch dimensions and ratios of ammonoids from the Gara el Itima.

\begin{tabular}{|c|c|c|c|c|c|c|c|c|c|c|}
\hline & $\mathrm{dm}$ & ww & wh & uw & ah & $\mathrm{ww} / \mathrm{dm}$ & ww/wh & $\mathrm{uw} / \mathrm{dm}$ & WER & IZW \\
\hline \multicolumn{11}{|l|}{ Irinoceras sp. } \\
\hline MB.C.9082.1 & 62.5 & 31.6 & 36.8 & 0.00 & 16.8 & 0.50 & 0.86 & 0.00 & 1.87 & 0.54 \\
\hline \multicolumn{11}{|c|}{ Itimaites parabolicus $\mathrm{n} . \mathrm{sp}$. } \\
\hline \multirow[t]{2}{*}{ MB.C.9086.1 } & 23.5 & 16.9 & 8.0 & 8.9 & - & 0.72 & 2.11 & 0.38 & - & - \\
\hline & 36.1 & - & - & - & 12.3 & - & - & - & 2.30 & - \\
\hline \multicolumn{11}{|c|}{ Calygirtyoceras zrigatense $\mathrm{sp}$. } \\
\hline MB.C. 9087.2 & 37.7 & 18.5 & 14.3 & 12.8 & - & 0.49 & 1.29 & 0.34 & - & - \\
\hline \multirow[t]{2}{*}{ MB.C.9087.1 } & 64.9 & - & 31.7 & 14.3 & 20.7 & - & - & 0.22 & 2.16 & 0.35 \\
\hline & 45.0 & 16.1 & 20.8 & 11.5 & - & 0.36 & 0.77 & 0.26 & - & - \\
\hline MB.C.9087.3 & 39.0 & 16.2 & 17.7 & 10.1 & 9.2 & 0.41 & 0.91 & 0.26 & 1.71 & 0.48 \\
\hline
\end{tabular}

Sulcogirtyoceras sp.

$\begin{array}{lcccccccccc}\text { MB.C.9073.3 } & 40.2 & 13.8 & 25.2 & 3.5 & 14.7 & 0.34 & 0.55 & 0.09 & 2.49 & 0.42 \\ \text { MB.C.9073.2 } & 44.5 & 15.8 & 26.0 & 3.6 & 16.7 & 0.36 & 0.61 & 0.08 & 2.56 & 0.36 \\ \text { MB.C.9073.1 } & 31.45 & 10.58 & 17.39 & 4.06 & 10.64 & 0.34 & 0.61 & 0.13 & 2.28 & 0.39 \\ & 14.92 & 6.85 & 7.33 & 3.49 & 3.92 & 0.46 & 0.94 & 0.23 & 1.84 & 0.47 \\ & 8.49 & 4.41 & 3.41 & 2.80 & 1.80 & 0.52 & 1.29 & 0.33 & 1.61 & 0.47 \\ & 5.38 & 2.92 & 1.57 & 2.61 & 1.21 & 0.54 & 1.87 & 0.48 & 1.66 & 0.23\end{array}$

Sudeticeras fornicum n. sp.

$\begin{array}{lllllllllll}\text { MB.C.9050 } & 72.3 & 36.3 & 35.8 & 8.7 & 17.6 & 0.50 & 1.01 & 0.12 & 1.74 & 0.51 \\ \text { MB.C.9093.1 } & 54.3 & 29.8 & 28.5 & 5.5 & 13.2 & 0.55 & 1.05 & 0.10 & 1.75 & 0.54 \\ \text { MB.C.9093.2 } & 39.5 & 22.0 & 21.9 & 3.4 & 11.1 & 0.56 & 1.00 & 0.08 & 1.94 & 0.49\end{array}$

Sudeticeras pusillobatum n. sp.

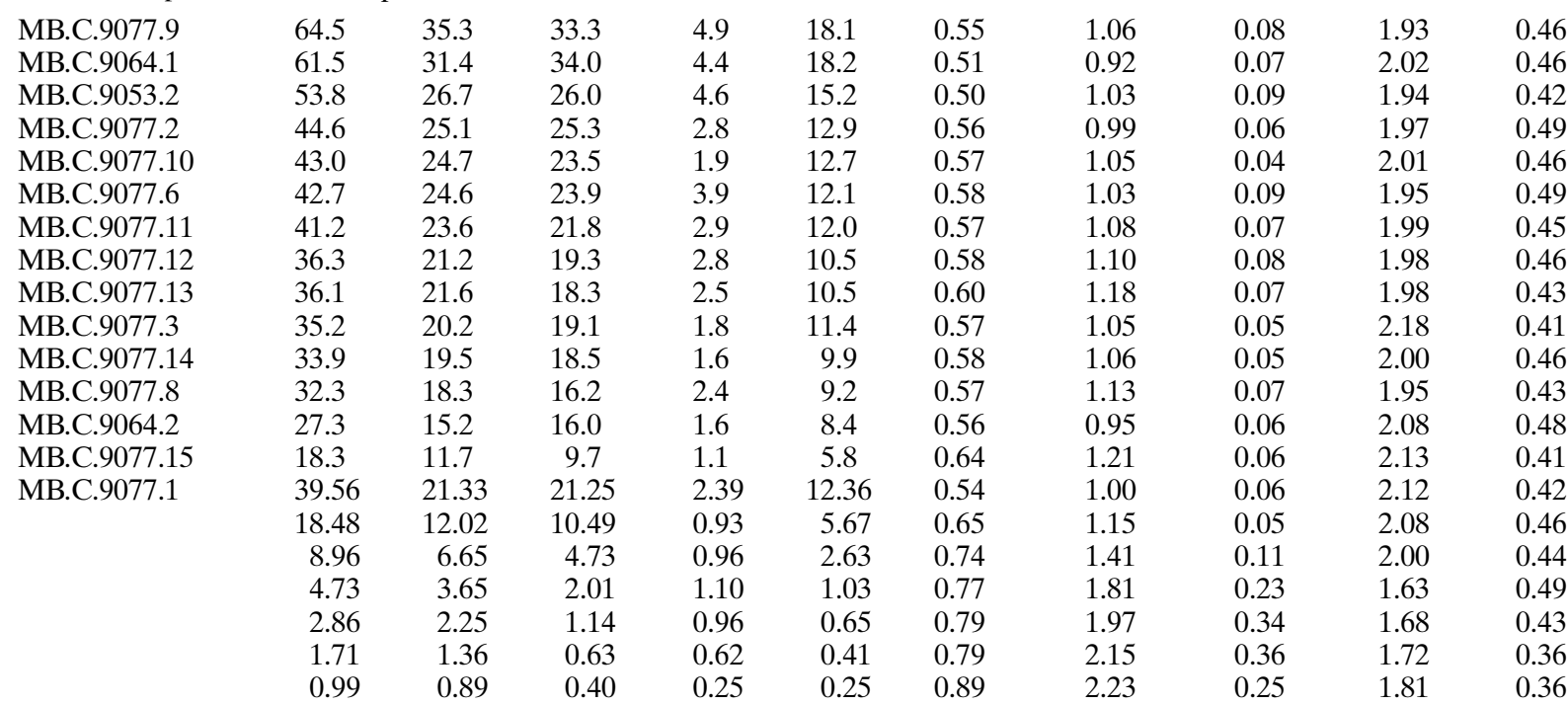

Sudeticeras occultornatum $\mathrm{n}$. sp.

$\begin{array}{lcccccccccc}\text { MB.C.9078.15 } & 77.9 & 39.9 & 43.7 & 5.0 & 22.1 & 0.51 & 0.91 & 0.06 & 1.95 & 0.49 \\ \text { MB.C.9078.16 } & 69.7 & 36.7 & 37.5 & 4.8 & 19.8 & 0.53 & 0.98 & 0.07 & 1.95 & 0.47 \\ \text { MB.C.9078.17 } & 64.1 & 36.2 & 34.4 & 4.4 & 17.8 & 0.56 & 1.05 & 0.07 & 1.91 & 0.48 \\ \text { MB.C.9078.8 } & 58.4 & 33.8 & 31.8 & 5.4 & 15.7 & 0.58 & 1.06 & 0.09 & 1.87 & 0.51 \\ \text { MB.C.9078.1 } & 53.5 & 32.1 & 28.4 & 4.3 & 14.8 & 0.60 & 1.13 & 0.08 & 1.91 & 0.48 \\ \text { MB.C.9078.18 } & 51.5 & 31.1 & 28.3 & 4.2 & 14.6 & 0.60 & 1.10 & 0.08 & 1.94 & 0.49 \\ \text { MB.C.9078.14 } & 50.1 & 29.1 & 28.0 & 5.1 & 14.5 & 0.58 & 1.04 & 0.10 & 1.98 & 0.48 \\ \text { MB.C.9078.9 } & 47.0 & 28.6 & 25.0 & 2.9 & 13.2 & 0.61 & 1.14 & 0.06 & 1.93 & 0.47 \\ \text { MB.C.9078.10 } & 44.5 & 28.3 & 26.3 & 3.1 & 13.1 & 0.63 & 1.07 & 0.07 & 2.00 & 0.50 \\ \text { MB.C.9063 } & 43.3 & 26.0 & 24.0 & 3.3 & 12.2 & 0.60 & 1.08 & 0.08 & 1.94 & 0.49 \\ \text { MB.C.9078.11 } & 38.1 & 23.9 & 21.0 & 2.7 & 10.8 & 0.63 & 1.14 & 0.07 & 1.95 & 0.48 \\ \text { MB.C.9078.12 } & 37.8 & 24.2 & 18.7 & 4.8 & 9.4 & 0.64 & 1.29 & 0.13 & 1.78 & 0.50 \\ \text { MB.C.9078.4 } & 25.94 & 16.41 & 14.53 & 1.11 & 7.59 & 0.63 & 1.13 & 0.04 & 2.00 & 0.48 \\ & 12.87 & 9.50 & 7.09 & 0.85 & 3.73 & 0.74 & 1.34 & 0.07 & 1.98 & 0.47 \\ & 6.57 & 5.30 & 3.34 & 0.94 & 1.58 & 0.81 & 1.59 & 0.14 & 1.73 & 0.53\end{array}$




\begin{tabular}{|c|c|c|c|c|c|c|c|c|c|c|}
\hline & $\mathrm{dm}$ & ww & wh & uw & $\mathrm{ah}$ & ww/dm & ww/wh & $\mathrm{uw} / \mathrm{dm}$ & WER & IZW \\
\hline \multirow{11}{*}{ MB.C.9078.3 } & 3.84 & 3.09 & 1.55 & 1.10 & 0.86 & 0.80 & 1.99 & 0.29 & 1.65 & 0.45 \\
\hline & 2.42 & 1.77 & 0.85 & 0.90 & 0.50 & 0.73 & 2.09 & 0.37 & 1.59 & 0.41 \\
\hline & 1.50 & 1.08 & 0.54 & 0.53 & 0.33 & 0.72 & 2.00 & 0.35 & 1.64 & 0.39 \\
\hline & 0.88 & 0.74 & 0.40 & 0.18 & 0.21 & 0.83 & 1.86 & 0.20 & 1.71 & 0.48 \\
\hline & 47.28 & 27.74 & 25.78 & 2.47 & 13.46 & 0.59 & 1.08 & 0.05 & 1.95 & 0.48 \\
\hline & 24.27 & 16.26 & 13.91 & 0.64 & 6.26 & 0.67 & 1.17 & 0.03 & 1.82 & 0.55 \\
\hline & 13.10 & 9.78 & 7.21 & 1.03 & 3.60 & 0.75 & 1.36 & 0.08 & 1.90 & 0.50 \\
\hline & 6.98 & 5.78 & 3.64 & 1.02 & 1.86 & 0.83 & 1.59 & 0.15 & 1.86 & 0.49 \\
\hline & 3.89 & 3.28 & 1.78 & 1.06 & 0.96 & 0.84 & 1.84 & 0.27 & 1.76 & 0.46 \\
\hline & 2.26 & 1.92 & 0.86 & 0.72 & 0.58 & 0.85 & 2.23 & 0.32 & 1.81 & 0.33 \\
\hline & 1.24 & 1.14 & 0.54 & 0.28 & 0.35 & 0.91 & 2.12 & 0.23 & 1.91 & 0.36 \\
\hline
\end{tabular}

Goniatites rodioni $\mathrm{n}$. $\mathrm{sp}$.

\begin{tabular}{|c|c|c|c|c|c|c|c|c|c|c|}
\hline MB.C.9084.1 & 69.0 & 45.0 & 31.0 & 8.3 & 13.4 & 0.65 & 1.45 & 0.12 & 1.54 & 0.57 \\
\hline MB.C.9084.10 & 58.7 & 41.2 & 29.2 & 6.9 & 13.4 & 0.70 & 1.41 & 0.12 & 1.68 & 0.54 \\
\hline MB.C.9084.11 & 52.3 & 39.2 & 25.7 & 7.5 & 10.5 & 0.75 & 1.52 & 0.14 & 1.57 & 0.59 \\
\hline MB.C.9084.12 & 50.0 & 34.6 & 24.7 & 4.6 & 9.1 & 0.69 & 1.40 & 0.09 & 1.49 & 0.63 \\
\hline MB.C.9084.13 & 46.5 & 36.6 & 23.0 & 5.2 & 10.1 & 0.79 & 1.59 & 0.11 & 1.63 & 0.56 \\
\hline MB.C.9084.8 & 44.2 & 33.5 & 22.5 & 5.4 & 8.3 & 0.76 & 1.49 & 0.12 & 1.51 & 0.63 \\
\hline MB.C.9084.2 & 41.9 & 32.6 & 19.9 & 5.5 & 9.10 & 0.78 & 1.64 & 0.13 & 1.63 & 0.54 \\
\hline MB.C.9084.4 & 38.9 & 34.4 & 18.5 & 3.3 & 7.0 & 0.88 & 1.86 & 0.08 & 1.49 & 0.62 \\
\hline MB.C.9084.5 & 35.3 & 28.9 & 17.0 & 2.7 & 7.2 & 0.82 & 1.70 & 0.08 & 1.58 & 0.58 \\
\hline \multirow[t]{3}{*}{ MB.C.9084.3 } & 45.65 & 32.92 & 22.13 & 5.82 & 9.29 & 0.72 & 1.49 & 0.13 & 1.58 & 0.58 \\
\hline & 29.28 & 24.91 & 14.52 & 2.30 & 5.96 & 0.85 & 1.72 & 0.08 & 1.58 & 0.59 \\
\hline & 18.91 & 17.34 & 9.42 & 1.00 & 4.06 & 0.92 & 1.84 & 0.05 & 1.62 & 0.57 \\
\hline \multirow[t]{5}{*}{ MB.C.9084.9 } & 34.03 & 31.20 & 17.25 & 3.88 & 6.77 & 0.92 & 1.81 & 0.11 & 1.56 & 0.61 \\
\hline & 22.21 & 23.97 & 11.51 & 1.31 & 4.00 & 1.08 & 2.08 & 0.06 & 1.49 & 0.65 \\
\hline & 15.09 & 16.05 & 7.92 & 0.85 & 3.19 & 1.06 & 2.03 & 0.06 & 1.61 & 0.60 \\
\hline & 9.37 & 10.49 & 4.78 & 0.48 & 1.87 & 1.12 & 2.20 & 0.05 & 1.56 & 0.61 \\
\hline & 5.86 & 6.84 & 3.03 & 0.31 & 1.22 & 1.17 & 2.26 & 0.05 & 1.59 & 0.60 \\
\hline
\end{tabular}

Goniatites gerberi n. sp.

\begin{tabular}{|c|c|c|c|c|c|c|c|c|c|c|}
\hline MB.C.9059 & 70.7 & 40.7 & 34.5 & 9.5 & 12.8 & 0.57 & 1.18 & 0.13 & 1.49 & 0.63 \\
\hline MB.C.9088.1 & 63.0 & 40.4 & 31.7 & 7.8 & 13.2 & 0.64 & 1.27 & 0.12 & 1.60 & 0.59 \\
\hline MB.C.9097.2 & 59.3 & 37.6 & 29.7 & 7.7 & 11.6 & 0.63 & 1.27 & 0.13 & 1.55 & 0.61 \\
\hline MB.C.9097.1 & 49.8 & 34.4 & 23.3 & 4.9 & 10.5 & 0.69 & 1.48 & 0.10 & 1.61 & 0.55 \\
\hline MB.C. 9088.8 & 44.6 & 30.1 & 21.6 & 4.9 & 8.6 & 0.68 & 1.39 & 0.11 & 1.53 & 0.60 \\
\hline MB.C.9088.4 & 42.3 & 30.5 & 22.0 & 4.6 & 9.3 & 0.72 & 1.38 & 0.11 & 1.64 & 0.58 \\
\hline MB.C.9088.9 & 39.3 & 29.2 & 22.1 & 4.8 & 8.5 & 0.74 & 1.32 & 0.12 & 1.63 & 0.62 \\
\hline MB.C.9088.6 & 29.1 & 22.8 & 13.8 & 3.6 & 5.2 & 0.78 & 1.64 & 0.12 & 1.48 & 0.63 \\
\hline MB.C.9088.7 & 28.9 & 23.2 & 14.4 & 3.1 & 5.1 & 0.80 & 1.61 & 0.11 & 1.47 & 0.65 \\
\hline MB.C.9088.5 & 27.4 & 21.8 & 13.5 & 2.8 & 5.9 & 0.79 & 1.62 & 0.10 & 1.63 & 0.56 \\
\hline MB.C. 9088.2 & 58.08 & 39.02 & 27.20 & 6.99 & 11.24 & 0.67 & 1.43 & 0.12 & 1.54 & 0.59 \\
\hline & 37.63 & 29.08 & 17.39 & 4.87 & 7.57 & 0.77 & 1.67 & 0.13 & 1.57 & 0.56 \\
\hline & 24.43 & 20.70 & 12.21 & 2.26 & 4.82 & 0.85 & 1.70 & 0.09 & 1.55 & 0.61 \\
\hline & 15.72 & 15.19 & 8.32 & 0.84 & 3.47 & 0.97 & 1.83 & 0.05 & 1.65 & 0.58 \\
\hline & 9.40 & 9.66 & 5.11 & 0.48 & 2.24 & 1.03 & 1.89 & 0.05 & 1.72 & 0.56 \\
\hline & 5.46 & 6.11 & 3.00 & 0.32 & 1.33 & 1.12 & 2.04 & 0.06 & 1.75 & 0.56 \\
\hline & 3.21 & 3.81 & 1.52 & 0.56 & 0.66 & 1.18 & 2.50 & 0.17 & 1.58 & 0.57 \\
\hline & 2.06 & 2.39 & 0.80 & 0.61 & 0.37 & 1.16 & 2.99 & 0.30 & 1.49 & 0.53 \\
\hline & 1.37 & 1.39 & 0.49 & 0.47 & 0.28 & 1.01 & 2.83 & 0.34 & 1.57 & 0.43 \\
\hline & 0.87 & 0.78 & 0.30 & 0.29 & 0.20 & 0.90 & 2.55 & 0.33 & 1.69 & 0.34 \\
\hline \multicolumn{11}{|c|}{ Goniatites evelinae n. sp. } \\
\hline MB.C.9058.1 & 55.1 & 37.0 & 26.0 & 8.3 & 10.7 & 0.67 & 1.42 & 0.15 & 1.54 & 0.59 \\
\hline MB.C. 9037.2 & 45.2 & 31.1 & 22.5 & 4.6 & 9.4 & 0.69 & 1.38 & 0.10 & 1.59 & 0.58 \\
\hline MB.C. 9069.2 & 39.5 & 30.3 & 17.2 & 6.0 & 7.5 & 0.77 & 1.76 & 0.15 & 1.52 & 0.56 \\
\hline MB.C.9037.1 & 32.5 & 24.2 & 16.5 & 3.0 & 6.7 & 0.74 & 1.46 & 0.09 & 1.59 & 0.59 \\
\hline MB.C.9069.1 & 31.9 & 21.9 & 15.0 & 4.7 & 6.9 & 0.68 & 1.46 & 0.15 & 1.62 & 0.54 \\
\hline \multirow[t]{8}{*}{ MB.C. 9058.2} & 32.94 & 24.78 & 15.48 & 4.15 & 6.22 & 0.75 & 1.60 & 0.13 & 1.52 & 0.60 \\
\hline & 21.87 & 16.72 & 11.39 & 1.13 & 4.81 & 0.76 & 1.47 & 0.05 & 1.64 & 0.58 \\
\hline & 12.82 & 10.66 & 7.11 & 0.28 & 3.16 & 0.83 & 1.50 & 0.02 & 1.76 & 0.56 \\
\hline & 7.18 & 6.57 & 4.00 & 0.22 & 1.83 & 0.92 & 1.64 & 0.03 & 1.80 & 0.54 \\
\hline & 3.95 & 3.88 & 2.09 & 0.38 & 0.95 & 0.98 & 1.86 & 0.10 & 1.74 & 0.54 \\
\hline & 2.33 & 2.21 & 0.93 & 0.70 & 0.47 & 0.95 & 2.37 & 0.30 & 1.57 & 0.49 \\
\hline & 1.50 & 1.28 & 0.49 & 0.49 & 0.28 & 0.85 & 2.59 & 0.33 & 1.51 & 0.44 \\
\hline & 0.95 & 0.72 & 0.37 & 0.26 & 0.27 & 0.76 & 1.95 & 0.28 & 1.96 & 0.27 \\
\hline
\end{tabular}




\begin{tabular}{|c|c|c|c|c|c|c|c|c|c|}
\hline & $\mathrm{dm}$ & ww & wh & uw & ah & $\mathrm{ww} / \mathrm{dm}$ & ww/wh & $\mathrm{uw} / \mathrm{dm}$ & WER \\
\hline \multicolumn{10}{|c|}{ Goniatites stenumbilicatus Kullmann, 1961} \\
\hline MB.C.9070 & 66.5 & 35.8 & 34.7 & 5.7 & 12.3 & 0.54 & 1.03 & 0.09 & 1.51 \\
\hline \multirow[t]{7}{*}{ MB.C.9060 } & 38.43 & 26.15 & 20.04 & 2.87 & 8.55 & 0.68 & 1.31 & 0.07 & 1.65 \\
\hline & 23.52 & 18.35 & 11.87 & 2.10 & 5.08 & 0.78 & 1.55 & 0.09 & 1.63 \\
\hline & 14.47 & 12.99 & 7.17 & 1.46 & 2.87 & 0.90 & 1.81 & 0.10 & 1.56 \\
\hline & 9.49 & 10.03 & 4.60 & 0.92 & 1.62 & 1.06 & 2.18 & 0.10 & 1.45 \\
\hline & 6.39 & 7.47 & 3.22 & 0.55 & 1.15 & 1.17 & 2.32 & 0.09 & 1.48 \\
\hline & 4.28 & 5.34 & 2.17 & 0.36 & 0.81 & 1.25 & 2.46 & 0.08 & 1.52 \\
\hline & 2.82 & 3.74 & 1.48 & 0.17 & 0.59 & 1.33 & 2.52 & 0.06 & 1.60 \\
\hline
\end{tabular}

Hypergoniatites fusiger $\mathrm{n}$. sp.

\begin{tabular}{|c|c|c|c|c|c|c|c|c|c|}
\hline MB.C.9081.1 & 42.3 & 22.9 & 21.3 & 4.1 & 12.6 & 0.54 & 1.08 & 0.10 & 2.03 \\
\hline MB.C.9081.5 & 22.7 & 15.1 & 12.0 & 1.9 & 6.6 & 0.66 & 1.26 & 0.08 & 1.97 \\
\hline MB.C.9081.6 & 18.8 & 13.2 & 9.4 & 1.4 & 5.1 & 0.70 & 1.41 & 0.08 & 1.88 \\
\hline MB.C.9081.7 & 13.9 & 11.4 & 8.0 & 0.9 & 3.7 & 0.82 & 1.42 & 0.06 & 1.85 \\
\hline \multirow[t]{9}{*}{ MB.C. 9081.2} & 51.04 & 25.17 & 26.92 & 4.94 & 15.73 & 0.49 & 0.94 & 0.10 & 2.09 \\
\hline & 25.55 & 15.76 & 14.27 & 1.33 & 6.80 & 0.62 & 1.10 & 0.05 & 1.86 \\
\hline & 14.01 & 10.55 & 7.44 & 1.17 & 3.60 & 0.75 & 1.42 & 0.08 & 1.81 \\
\hline & 7.55 & 7.64 & 4.06 & 0.58 & 2.08 & 1.01 & 1.88 & 0.08 & 1.90 \\
\hline & 4.26 & 5.29 & 2.02 & 0.52 & 0.80 & 1.24 & 2.62 & 0.12 & 1.51 \\
\hline & 2.79 & 3.73 & 1.32 & 0.39 & 0.55 & 1.34 & 2.83 & 0.14 & 1.56 \\
\hline & 1.79 & 2.36 & 0.80 & 0.33 & 0.35 & 1.32 & 2.95 & 0.19 & 1.54 \\
\hline & 1.15 & 1.41 & 0.50 & 0.22 & 0.26 & 1.23 & 2.81 & 0.19 & 1.66 \\
\hline & 0.70 & 0.88 & 0.29 & 0.15 & 0.17 & 1.26 & 2.99 & 0.22 & 1.77 \\
\hline \multirow[t]{8}{*}{ MB.C.9081.3 } & 45.69 & 23.71 & 25.14 & 3.12 & 14.67 & 0.52 & 0.94 & 0.07 & 2.17 \\
\hline & 21.28 & 14.72 & 11.93 & 1.24 & 6.39 & 0.69 & 1.23 & 0.06 & 2.04 \\
\hline & 10.60 & 8.78 & 5.68 & 0.77 & 2.94 & 0.83 & 1.55 & 0.07 & 1.91 \\
\hline & 5.82 & 6.24 & 3.15 & 0.29 & 1.35 & 1.07 & 1.98 & 0.05 & 1.70 \\
\hline & 3.57 & 4.60 & 1.84 & 0.31 & 0.78 & 1.29 & 2.49 & 0.09 & 1.63 \\
\hline & 2.23 & 3.11 & 1.09 & 0.31 & 0.42 & 1.39 & 2.85 & 0.14 & 1.51 \\
\hline & 1.49 & 2.00 & 0.73 & 0.28 & 0.28 & 1.34 & 2.75 & 0.19 & 1.52 \\
\hline & 0.96 & 1.15 & 0.45 & 0.23 & 0.20 & 1.20 & 2.58 & 0.24 & 1.58 \\
\hline
\end{tabular}

Neogoniatites worki $\mathrm{n} . \mathrm{sp}$.

$\begin{array}{lllllllllll}\text { MB.C.9074.3 } & 51.3 & 29.7 & 24.5 & 4.3 & 11.4 & 0.58 & 1.21 & 0.08 & 1.65 & 0.53 \\ \text { MB.C.9091.1 } & 50.4 & 31.6 & 23.8 & 4.7 & 11.3 & 0.63 & 1.33 & 0.09 & 1.66 & 0.53 \\ \text { MB.C.9074.2 } & 44.6 & 30.1 & 21.5 & 3.7 & 8.9 & 0.67 & 1.40 & 0.08 & 1.56 & 0.59 \\ \text { MB.C.9074.1 } & 37.83 & 26.64 & 18.84 & 3.26 & 7.81 & 0.70 & 1.41 & 0.09 & 1.59 & 0.59 \\ & 23.54 & 19.68 & 12.30 & 1.44 & 4.69 & 0.84 & 1.60 & 0.06 & 1.56 & 0.62 \\ & 15.13 & 14.02 & 7.95 & 1.03 & 3.26 & 0.93 & 1.76 & 0.07 & 1.62 & 0.59 \\ & 9.40 & 9.11 & 4.90 & 0.88 & 1.86 & 0.97 & 1.86 & 0.09 & 1.55 & 0.62 \\ & 6.14 & 6.02 & 3.07 & 0.77 & 1.17 & 0.98 & 1.96 & 0.12 & 1.52 & 0.62 \\ & 4.03 & 3.99 & 1.95 & 0.63 & 0.77 & 0.99 & 2.04 & 0.16 & 1.53 & 0.61 \\ & 2.57 & 2.39 & 1.16 & 0.66 & 0.62 & 0.93 & 2.07 & 0.26 & 1.74 & 0.46 \\ & 1.46 & 1.28 & 0.63 & 0.39 & 0.38 & 0.88 & 2.04 & 0.27 & 1.84 & 0.39\end{array}$

Dombarites granofalcatus (Kullmann, 1961)

\begin{tabular}{|c|c|c|c|c|c|c|c|c|c|c|}
\hline IGT 1851-95 & 84.4 & 52.0 & 35.8 & 18.3 & 14.2 & 0.62 & 1.45 & 0.22 & 1.45 & 0.60 \\
\hline IGT 1851-94 & 78.0 & 46.5 & 32.2 & 20.0 & 13.5 & 0.60 & 1.44 & 0.26 & 1.46 & 0.58 \\
\hline IGT 1851-93 & 65.8 & 42.3 & 27.3 & 18.0 & - & 0.64 & 1.55 & 0.27 & - & - \\
\hline MB.C.9031.1 & 63.9 & 40.1 & 24.3 & 18.0 & 9.8 & 0.63 & 1.65 & 0.28 & 1.40 & 0.60 \\
\hline MB.C.9090.5 & 57.1 & 34.9 & 24.5 & 14.4 & 9.0 & 0.61 & 1.42 & 0.25 & 1.41 & 0.63 \\
\hline MB.C.3774 & 53.9 & 34.1 & 22.2 & 12.4 & 8.1 & 0.63 & 1.53 & 0.23 & 1.39 & \\
\hline MB.C.9031.4 & 49.6 & 32.4 & 19.0 & 12.8 & 9.0 & 0.65 & 1.71 & 0.26 & 1.49 & \\
\hline MB.C. 9090.2 & 49.6 & 34.5 & 20.9 & 11.7 & 8.2 & 0.69 & 1.65 & 0.24 & 1.43 & 0.61 \\
\hline MB.C. 9090.4 & 43.9 & 28.4 & 18.0 & 10.0 & 6.8 & 0.65 & 1.58 & 0.23 & 1.40 & 0.62 \\
\hline MB.C. 9031.2 & 28.5 & 22.9 & 11.8 & 6.4 & 4.6 & 0.80 & 1.94 & 0.22 & 1.42 & 0.61 \\
\hline \multirow[t]{12}{*}{ MB.C.9090.1 } & 66.26 & 39.23 & 27.46 & 16.02 & 10.19 & 0.59 & 1.43 & 0.24 & 1.40 & 0.63 \\
\hline & 47.61 & 29.31 & 19.88 & 10.75 & 8.32 & 0.62 & 1.47 & 0.23 & 1.47 & \\
\hline & 32.85 & 22.11 & 14.11 & 6.14 & 5.40 & 0.67 & 1.57 & 0.19 & 1.43 & \\
\hline & 22.51 & 15.94 & 10.46 & 3.44 & 4.25 & 0.71 & 1.52 & 0.15 & 1.52 & \\
\hline & 14.49 & 11.99 & 6.91 & 2.34 & 2.88 & 0.83 & 1.74 & 0.16 & 1.56 & \\
\hline & 9.61 & 8.48 & 4.40 & 1.86 & 1.71 & 0.88 & 1.93 & 0.19 & 1.48 & \\
\hline & 6.54 & 6.06 & 2.68 & 1.94 & 1.21 & 0.93 & 2.26 & 0.30 & 1.51 & \\
\hline & 4.39 & 4.16 & 1.66 & 1.59 & 0.80 & 0.95 & 2.50 & 0.36 & 1.49 & 0. \\
\hline & 2.94 & 2.74 & 1.04 & 1.16 & 0.55 & 0.93 & 2.64 & 0.39 & 1.51 & 0.47 \\
\hline & 1.98 & 1.69 & 0.62 & 0.83 & 0.36 & 0.85 & 2.73 & 0.42 & 1.50 & 0.41 \\
\hline & 1.28 & 0.99 & 0.39 & 0.55 & 0.29 & 0.77 & 2.54 & 0.43 & 1.66 & 0.2 \\
\hline & 0.76 & 0.63 & 0.32 & 0.19 & 0.20 & 0.82 & 1.94 & 0.25 & 1.85 & \\
\hline
\end{tabular}




\begin{tabular}{|c|c|c|c|c|c|c|c|c|c|c|}
\hline & $\mathrm{dm}$ & ww & wh & uw & $\mathrm{ah}$ & ww/dm & ww/wh & $\mathrm{uw} / \mathrm{dm}$ & WER & IZW \\
\hline \multirow[t]{5}{*}{ MB.C.3773 } & 4.84 & 4.93 & 1.82 & 1.45 & 0.86 & 1.02 & 2.70 & 0.30 & 1.48 & 0.53 \\
\hline & 3.25 & 3.27 & 1.14 & 1.25 & 0.59 & 1.01 & 2.86 & 0.38 & 1.49 & 0.49 \\
\hline & 2.20 & 2.04 & 0.69 & 0.96 & 0.38 & 0.92 & 2.94 & 0.44 & 1.47 & 0.45 \\
\hline & 1.50 & 1.27 & 0.43 & 0.69 & 0.28 & 0.85 & 2.94 & 0.46 & 1.52 & 0.34 \\
\hline & 0.95 & 0.74 & 0.31 & 0.37 & 0.20 & 0.78 & 2.39 & 0.39 & 1.59 & 0.36 \\
\hline
\end{tabular}

Dombarites bellornatus n. sp.

$\begin{array}{lllllllllll}\text { MB.C.9072.1 } & 55.0 & 34.2 & 26.9 & 7.0 & - & 0.62 & 1.27 & 0.13 & - & - \\ \text { MB.C.9061 } & 54.7 & 33.6 & 27.4 & 6.1 & 13.1 & 0.61 & 1.23 & 0.11 & 1.73 & 0.52 \\ \text { MB.C.9083 } & 69.4 & - & 34.4 & 10.0 & 16.1 & - & - & 0.14 & 1.69 & 0.53 \\ \text { MB.C.9072.2 } & 28.26 & 20.01 & 13.20 & 4.12 & 5.22 & 0.71 & 1.52 & 0.15 & 1.50 & 0.60 \\ & 18.47 & 14.61 & 9.04 & 2.53 & 3.63 & 0.79 & 1.62 & 0.14 & 1.55 & 0.60 \\ & 12.04 & 10.44 & 5.82 & 1.81 & 2.34 & 0.87 & 1.80 & 0.15 & 1.54 & 0.60 \\ & 7.94 & 7.36 & 3.72 & 1.28 & 1.39 & 0.93 & 1.98 & 0.16 & 1.47 & 0.63 \\ & 5.44 & 5.01 & 2.47 & 1.10 & 0.98 & 0.92 & 2.02 & 0.20 & 1.48 & 0.61\end{array}$

Platygoniatites rhanemensis n. sp.

\begin{tabular}{|c|c|c|c|c|c|c|c|c|c|c|}
\hline MB.C.9044.1 & 103.1 & 48.0 & 43.0 & 22.6 & 15.9 & 0.47 & 1.12 & 0.22 & 1.40 & 0.63 \\
\hline MB.C.9079.1 & 90.2 & 40.7 & 38.1 & 18.8 & 14.4 & 0.45 & 1.07 & 0.21 & 1.42 & 0.62 \\
\hline MB.C.9079.6 & 78.1 & 35.9 & 31.6 & 16.8 & 11.8 & 0.46 & 1.14 & 0.22 & 1.39 & 0.63 \\
\hline MB.C.9079.17 & 73.7 & 36.7 & 30.5 & 14.0 & 11.3 & 0.50 & 1.20 & 0.19 & 1.39 & 0.63 \\
\hline MB.C.9079.15 & 73.5 & 40.1 & 33.9 & 15.3 & 11.5 & 0.55 & 1.18 & 0.21 & 1.41 & 0.66 \\
\hline MB.C.9051.2 & 72.4 & 37.6 & 33.3 & 14.7 & 12.4 & 0.52 & 1.13 & 0.20 & 1.45 & 0.63 \\
\hline MB.C.9079.18 & 61.2 & 30.0 & 26.5 & 12.0 & 10.3 & 0.49 & 1.13 & 0.20 & 1.44 & 0.61 \\
\hline MB.C.9051.3 & 59.1 & 30.1 & 26.4 & 10.1 & 9.7 & 0.51 & 1.14 & 0.17 & 1.43 & 0.63 \\
\hline MB.C.9079.12 & 54.5 & 28.7 & 24.8 & 8.9 & 9.3 & 0.53 & 1.16 & 0.16 & 1.46 & 0.62 \\
\hline MB.C.9079.19 & 46.2 & 26.2 & 20.4 & 7.9 & 7.4 & 0.57 & 1.28 & 0.17 & 1.42 & 0.64 \\
\hline MB.C.9079.20 & 43.8 & 23.1 & 20.8 & 7.8 & 7.0 & 0.53 & 1.11 & 0.18 & 1.42 & 0.66 \\
\hline MB.C.9079.8 & 43.3 & 25.5 & 20.3 & 6.9 & 7.4 & 0.59 & 1.26 & 0.16 & 1.45 & 0.64 \\
\hline MB.C.9079.21 & 37.2 & 21.3 & 18.3 & 4.7 & 6.5 & 0.57 & 1.17 & 0.13 & 1.47 & 0.64 \\
\hline MB.C.9079.9 & 25.0 & 16.5 & 11.8 & 2.9 & 4.3 & 0.66 & 1.39 & 0.11 & 1.45 & 0.64 \\
\hline \multirow[t]{10}{*}{ MB.C.9079.3 } & 43.34 & 24.48 & 20.07 & 6.16 & 7.58 & 0.56 & 1.22 & 0.14 & 1.47 & 0.62 \\
\hline & 29.31 & 17.51 & 14.27 & 3.29 & 5.47 & 0.60 & 1.23 & 0.11 & 1.51 & 0.62 \\
\hline & 19.07 & 13.26 & 9.81 & 1.75 & 3.32 & 0.69 & 1.35 & 0.09 & 1.47 & 0.66 \\
\hline & 13.11 & 9.61 & 6.79 & 1.13 & 2.21 & 0.73 & 1.42 & 0.09 & 1.45 & 0.67 \\
\hline & 9.08 & 7.13 & 4.39 & 1.20 & 1.45 & 0.78 & 1.62 & 0.13 & 1.42 & 0.67 \\
\hline & 6.30 & 5.16 & 2.99 & 1.13 & 1.03 & 0.82 & 1.73 & 0.18 & 1.43 & 0.66 \\
\hline & 4.42 & 3.52 & 1.98 & 1.11 & 0.83 & 0.80 & 1.78 & 0.25 & 1.52 & 0.58 \\
\hline & 2.90 & 2.27 & 1.15 & 0.96 & 0.59 & 0.78 & 1.97 & 0.33 & 1.57 & 0.49 \\
\hline & 1.84 & 1.48 & 0.61 & 0.73 & 0.45 & 0.80 & 2.41 & 0.40 & 1.74 & 0.27 \\
\hline & 1.04 & 0.99 & 0.41 & 0.25 & 0.28 & 0.95 & 2.41 & 0.24 & 1.90 & 0.31 \\
\hline \multirow[t]{11}{*}{ MB.C.9079.2 } & 58.98 & 29.66 & 26.55 & 10.13 & 9.53 & 0.50 & 1.12 & 0.17 & 1.42 & 0.64 \\
\hline & 41.24 & 22.86 & 19.53 & 5.87 & 7.29 & 0.55 & 1.17 & 0.14 & 1.48 & 0.63 \\
\hline & 27.76 & 16.99 & 13.58 & 3.10 & 5.39 & 0.61 & 1.25 & 0.11 & 1.54 & 0.60 \\
\hline & 18.23 & 13.91 & 9.03 & 1.68 & 3.34 & 0.76 & 1.54 & 0.09 & 1.50 & 0.63 \\
\hline & 12.26 & 10.41 & 5.97 & 1.20 & 2.09 & 0.85 & 1.74 & 0.10 & 1.45 & 0.65 \\
\hline & 8.29 & 7.47 & 3.95 & 1.19 & 1.49 & 0.90 & 1.89 & 0.14 & 1.49 & 0.62 \\
\hline & 5.57 & 5.01 & 2.59 & 0.97 & 0.97 & 0.90 & 1.94 & 0.17 & 1.46 & 0.63 \\
\hline & 3.82 & 3.24 & 1.68 & 1.01 & 0.59 & 0.85 & 1.93 & 0.26 & 1.40 & 0.65 \\
\hline & 2.70 & 2.14 & 1.01 & 0.98 & 0.47 & 0.79 & 2.13 & 0.36 & 1.47 & 0.53 \\
\hline & 1.83 & 1.37 & 0.60 & 0.78 & 0.35 & 0.75 & 2.29 & 0.43 & 1.52 & 0.42 \\
\hline & 1.21 & 0.84 & 0.41 & 0.47 & 0.26 & 0.69 & 2.06 & 0.39 & 1.63 & 0.36 \\
\hline \multicolumn{11}{|c|}{ Ferganoceras torridum n. sp. } \\
\hline \multirow[t]{2}{*}{ MB.C.9071 } & 30.2 & 11.5 & 13.2 & 7.4 & 6.8 & 0.38 & 0.87 & 0.24 & 1.67 & 0.49 \\
\hline & 24.3 & 10.1 & 10.5 & 6.4 & - & 0.41 & 0.96 & 0.26 & - & - \\
\hline \multicolumn{11}{|c|}{ Prolecanites maeandricus n. sp. } \\
\hline MB.C.9085.1 & 32.4 & 11.5 & 12.1 & 14.5 & - & 0.36 & 0.95 & 0.45 & - & - \\
\hline \multicolumn{11}{|c|}{ Prolecanites mapesi n. sp. } \\
\hline MB.C.9080.1 & 47.3 & 11.4 & 17.3 & 18.1 & 15.1 & 0.24 & 0.65 & 0.38 & 2.16 & 0.13 \\
\hline MB.C. 9080.4 & 36.5 & 9.7 & 13.4 & 14.3 & 12.1 & 0.27 & 0.73 & 0.39 & 2.24 & 0.09 \\
\hline MB.C.9080.6 & 34.7 & 9.8 & 12.8 & 13.4 & 11.9 & 0.28 & 0.77 & 0.38 & 2.31 & 0.07 \\
\hline MB.C. 9080.3 & 30.3 & 8.2 & 10.9 & 12.3 & 9.9 & 0.27 & 0.75 & 0.41 & 2.21 & 0.09 \\
\hline MB.C. 9080.7 & 29.9 & 8.2 & 11.2 & 11.0 & 9.7 & 0.27 & 0.73 & 0.37 & 2.19 & 0.14 \\
\hline MB.C.9080.8 & 29.9 & 7.7 & 11.2 & 11.7 & 9.7 & 0.26 & 0.69 & 0.39 & 2.19 & 0.13 \\
\hline MB.C.9080.9 & 29.0 & 7.6 & 10.1 & 11.3 & 9.4 & 0.26 & 0.76 & 0.39 & 2.19 & 0.06 \\
\hline
\end{tabular}




\begin{tabular}{llccccccccc}
\hline & dm & ww & wh & uw & ah & ww/dm & ww/wh & uw/dm & WER & IZW \\
\hline MB.C.9080.10 & 28.1 & 7.1 & 10.6 & 11.1 & 9.2 & 0.25 & 0.67 & 0.39 & 2.22 & 0.13 \\
MB.C.9080.11 & 24.4 & 6.1 & 8.9 & 9.3 & 7.9 & 0.25 & 0.69 & 0.38 & 2.18 & 0.11 \\
MB.C.9080.2 & 45.54 & 10.81 & 16.33 & 18.46 & 14.57 & 0.24 & 0.66 & 0.41 & 2.16 & 0.11 \\
& 21.29 & 5.52 & 7.12 & 9.49 & 6.61 & 0.26 & 0.77 & 0.45 & 2.10 & 0.07 \\
& 10.57 & 3.16 & 3.36 & 7.21 & 3.17 & 0.30 & 0.94 & - & 2.04 & 0.05
\end{tabular}

Epicanites hamianensis $\mathrm{n}$. $\mathrm{sp}$.

$\begin{array}{lcccccccccc}\text { MB.C.9075.9 } & 75.3 & 25.1 & 33.8 & 20.5 & 28.5 & 0.33 & 0.74 & 0.27 & 2.59 & 0.15 \\ \text { MB.C.9075.3 } & 66.9 & 23.0 & 29.9 & 18.3 & 26.1 & 0.34 & 0.77 & 0.27 & 2.69 & 0.13 \\ \text { MB.C.9075.1 } & 65.6 & 22.1 & 28.4 & 19.3 & 24.2 & 0.34 & 0.78 & 0.29 & 2.51 & 0.15 \\ \text { MB.C.9075.2 } & 64.7 & 22.7 & 29.6 & 18.2 & 25.7 & 0.35 & 0.77 & 0.28 & 2.75 & 0.13 \\ \text { MB.C.9054.2 } & 48.6 & 15.4 & 19.8 & 15.4 & 17.6 & 0.32 & 0.78 & 0.32 & 2.46 & 0.11 \\ \text { MB.C.9075.5 } & 47.9 & 15.7 & 20.3 & 14.4 & 16.7 & 0.33 & 0.77 & 0.30 & 2.35 & 0.18 \\ \text { MB.C.9075.10 } & 46.1 & 15.6 & 20.0 & 13.2 & 17.3 & 0.34 & 0.78 & 0.29 & 2.56 & 0.14 \\ \text { MB.C.9075.7 } & 43.6 & 14.4 & 18.9 & 12.0 & 15.4 & 0.33 & 0.76 & 0.27 & 2.39 & 0.19 \\ \text { MB.C.9075.4 } & 35.1 & 12.6 & 15.3 & 10.1 & 13.5 & 0.36 & 0.82 & 0.29 & 2.64 & 0.12 \\ \text { MB.C.9075.11 } & 18.2 & 6.5 & 8.1 & 6.3 & 6.1 & 0.36 & 0.80 & 0.35 & 2.27 & 0.25 \\ \text { MB.C.9054.1 } & 57.22 & 18.96 & 24.21 & 18.21 & 21.40 & 0.33 & 0.78 & 0.32 & 2.55 & 0.12 \\ & 22.72 & 7.86 & 9.07 & 8.04 & 8.00 & 0.35 & 0.87 & 0.35 & 2.38 & 0.12 \\ & 9.66 & 3.29 & 3.31 & 4.09 & 3.00 & 0.34 & 0.99 & 0.42 & 2.10 & 0.09 \\ & 4.62 & 1.68 & 1.62 & 1.92 & 1.44 & 0.36 & 1.04 & 0.42 & 2.11 & 0.11 \\ & 2.32 & 0.85 & 0.80 & 1.52 & 0.69 & 0.37 & 1.07 & - & 2.02 & 0.14\end{array}$

Megapronorites itimensis n. sp.

$\begin{array}{lllllllllll}\text { MB.C.9076.6 } & 90.9 & - & - & - & 31.3 & - & - & - & 2.32 & - \\ \text { MB.C.9076.1 } & 59.6 & 16.8 & 30.4 & 10.1 & - & 0.28 & 0.55 & 0.17 & - & - \\ \text { MB.C.9076.5 } & 85.7 & 27.4 & 40.8 & 11.6 & 28.2 & 0.32 & 0.67 & 0.14 & 2.22 & 0.31 \\ \text { MB.C.9055 } & 64.0 & 21.9 & 30.4 & 13.4 & 22.9 & 0.34 & 0.72 & 0.21 & 2.42 & 0.25 \\ \text { MB.C.9076.2 } & 62.8 & 16.6 & 30.1 & 11.0 & 20.5 & 0.26 & 0.55 & 0.18 & 2.21 & 0.32 \\ & 49.45 & 14.90 & 24.65 & 9.86 & 17.30 & 0.30 & 0.60 & 0.20 & 2.37 & 0.30 \\ & 22.59 & 5.31 & 8.81 & 8.07 & 6.97 & 0.24 & 0.60 & 0.36 & 2.09 & 0.21 \\ & 10.64 & 2.73 & 3.85 & 5.65 & 3.40 & 0.26 & 0.88 & 0.46 & 2.16 & 0.12\end{array}$

